Review

\title{
BIOMARKERS AND THEIR POTENTIAL USE IN TRANSPLANTATION
}

\author{
Rafails Rozentāls, Jānis Jušinskis, and Diāna Amerika \\ Transplant Laboratory, Rīga Stradinš̌ University, Dzirciema iela 16, Rīga, LV-1002, LATVIA; \\ Rafails.Rozentals@rsu.Iv
}

Contributed by Rafails Rozentāls

\begin{abstract}
The article presents an overview of literature related to two topical issues in modern medicine: transplantation and biomarkers. There have been advances made in the use of immunoenzymometric and immunoadsorption assays in organ transplantation clinics for evaluating different situations. However, these methods fail to solve more complex and ambiguous transplantation problems: tolerance, personification of treatment, etc. In this regard, the first results of prospective studies using OMICS methods of genomics and proteinomics, in relation to the notion of transplantomics, are presented.
\end{abstract}

Key words: organ transplantation, biomarkers, clinical and biochemical studies, immunoenzymometric and immunoabsorption methods, transplantomics.

\section{INTRODUCTION}

In recent decades advances have been made in the development of transplantation. In Europe more than 30 thousand transplants of organs (kidneys, liver, heart, lungs, and pancreas) are made yearly. New immunosuppressants have been brought into practice, which have allowed to achieve $90 \%$ implant survival for one year. The main unsolved problem is still securing long-term survival of allografts, the function of which progressively decreases within 5 to 10 years (Nankivel and Chapmen, 2006). It is still not possible to significantly reduce the period and the degree of chronic allograft injuries. Available radiological, clinical and biochemical and pathohistological methods of diagnostics and the available treatment used in practice are not sufficient to evaluate all difficulties in selection of organs, prevention of ischemia-reperfusion complications, understanding of transplant pathophysiology, etc. (Danovitch, 2010). Clinical and diagnostic problems such as acute and chronic rejections, infections, nephrotoxicity of immunosuppressive drugs remain important issues. It is still not clear how to assess the numerous processes taking place in allografts (immunological, reperfusion, mutational, etc.). Studies of processes taking place in the patient and their allografts under conditions of immunosuppressive therapy combining different drugs are of particular importance (Stock and Kirk, 2011). These drugs have side effects that can cause infections, nephrotoxicity, hypertension, and diabetes. Therefore, it is rather difficult to standardise post-transplant treatment.

\section{THE ROLE OF BIOMARKERS IN MEDICINE}

New biomedical technologies, among which particular attention is paid to the study of biological markers (biomarkers), can be used to solve transplantation problems. Biomarkers are characteristics that can be objectively measured in a human and evaluated as indicators of normal biologic processes, pathogenic processes, expected future disease development, and responses to pharmacological and therapeutic interventions. These indicators are distributed within a population, present in biological substances and are indicators of specific physiological and pathological conditions of the body (Anonymous, 2001). Biomarkers must be quantitative diagnostic endpoints, specific for each body and must, at the same time, demonstrate the extent of its injury. They must be easily measurable, simple and cheap. The main role of biomarkers in the clinic lies in the study of the course of diseases, assessment of the risk of their development based on noninvasive techniques, prognostication, as well as revealing the efficacy of therapeutic measures (Vasan, 2006).

Three types of biomarkers have been distinguished:

Type 0. A marker of a specific disease which correlates with known clinical indices. Biomarkers of tumours and cardiovascular diseases are widely known and used in practical work (Foster and Cooper, 2006).

Type 1. A marker that captures and assesses the effects of a therapeutic intervention in accordance with its mechanism of therapeutic action. 
Type 2. Surrogate end point. The marker intended to substitute a clinical end point. A surrogate end point is expected to predict clinical benefit (or harm or lack of benefit) on the basis of epidemiological, therapeutic, pathophysiological or other scientific evidence (De Gruttola, 2001).

There are many problems in transplantation that must be solved through studies of biomarkers: study of pheno- and genotype of patients with the aim to determine fitness for transplantation treatment; discovery of risk factors of the development of acute and chronic rejection, early diagnostics of rejection, determination of its type, prognostication of treatment outcomes and tailoring of immunosuppressive therapy in a cost-effective manner (Springers et al., 2011).

Donors and recipients of renal allografts are the best models to study biomarkers in transplantation. This may be explained by a significantly higher number of renal transplantations compared to other organs, and by the possibility to conduct studies at the same time in blood, urine and renal allograft focusing on cells infiltrating walls of its tubules (Gillespie and Lee, 2008). Moreover, there have been advancements in use of biomarkers in the diagnostics and prognostication of acute renal failure, and this information can be extrapolated to studies of the structure and function of renal allografts (McIlroy et al., 2010).

\section{CLINICAL AND BIOCHEMICAL CRITERIA}

Currently, clinical and biochemical criteria are the most widespread methods of diagnostics in pre and post kidney transplantation patients. The determination of blood serum creatinine is a "gold standard" in the assessment of allograft function. This criterion fully suits clinicians, since it reflects the degree of preservation of glomerular filtration. However, changes in the creatinine level take place only when it drops to 50\% (Waikar et al., 2012). The blood creatinine level is not sufficient to diagnose a complicated pathology of a renal allograft, the nature of rejections, the effect of immunisuppressive therapy, possible tolerance, etc.

Other endpoints used in nephrologic clinics are also important. Proteinuria, for example, is a diagnostic and prognostic criterion for the development of pathology of original kidneys and also renal allografts. However, the estimated level of proteinuria not only estimates renal dysfunction, but also characterizes the consequences of pathological processes taking place in allografts (Calabuig et al., 2012). In the post-transplant period, significant importance is paid to serum albumin concentration. An association between serum albumin concentration and kidney transplant outcome has been established (Molnar et al., 2011). Clinical and biochemical endpoints are also used in transplantation of other organs: activity of serum transaminase in cases of transplants of liver; and blood glucose and amylase concentrations in cases of pancreas transplants (Hrick, 2011). Increased activity of lysosomal enzymes, glutathione S-transferase and N-acetyl-beta-D-glucosaminidase in perfusate during machine preservation of kidneys, indicates the beginning of injury (Graetz et al., 2009). Although the above mentioned clinical endpoints apparently have clinical value, it should be noted that they are not specific and depend on a large range of numerous side effects related to the disease and transplantation.

Histopathological studies of allografts allow more accurate diagnostics. The Banff Classification allows to determine different forms of rejection (Henderson et al., 2011). The presence of CD4 antibodies in peritubular capillaries of a renal allograft indicate humoral nature of an acute rejection (Loupy et al., 2011). These observed changes are however not always specific and many pathological findings remain unexplained. It is not clear how to interpret borderline changes identified in biopsies, the meaning of cellular infiltration without tubulitis, etc. (Snanoudj et al., 2011).

In immunological monitoring under conditions of immunosuppressive therapy, the assessment of the whole complex of clinical and morphological criteria as biomarkers showed their shortcomings in the prognostication of the development of pathological processes and in determination of pretransplantation risk factors. These criteria are able to diagnose only the final stage of development of pathophysiological shifts.

\section{MOLECULAR-LEVEL STUDIES}

Further development of biomarkers was aided by molecular-level studies. Advancements in the diagnostics and prognostication of the development of acute renal failure allowed their use in renal transplantation clinics (Coca et al., 2008). A significant number of biomarkers were proposed, but only Cystatin C, NGAL (neutrophil gelatinase-associated lipocalin), IL-18 (interleukin), and KIM-1 (kidney injury molecule) should be considered to be the most prospective. Cystatin C (low-molecular-weight protein cysteine) is a marker of glomerular filtration and reflects its level much more accurately than blood creatinine. For fast diagnostics of acute renal injuries in renal allografts, NGAL is most frequently used (Jushinskis et al., 2011). It is a low molecular weight protein located in neutrophiles and the epithelium, including proximal renal tubules in the epithelium. In cases of ischemic kidney injury, urine NGAL concentrations increase. Its dynamic changes in urine and blood are successful for determination of the extent and rate of restoration of function of renal allografts after surgery (Hollmen et al., 2011). IL-18 protein, a mediator of tubular necrosis, induces neutrophil and monocyte infiltration of tubules during ischemia. A dynamic study of NGAL along with IL-18 is efficient for the prognostication of the development of delayed function and control of its recovery (Parikh et al., 2006). Neopterin and C-reactive protein are used as markers of cell-mediated immunity when transplanting heart. Their elevation in urine and blood respectively indicate development of an acute rejection (Johnson et al., 2011).

Improved diagnostics and prognostication of acute injuries to renal allografts based on molecular tests using en- 
zyme-linked immunosorbent assay methods (ELISA) have been shown to have low efficiency in the solution of many other transplantation problems: determination of mechanisms and pathophysiology of immune response, early diagnostics of rejections, and prognostication of the risk of development of complications after organ transplantation.

Biomarkers to carry out complex multi-factor diagnostics are needed. Some of these methods have already been used in clinics. To prognosticate the most dangerous antibodymediated rejection, the level of donor-specific antibodies can be determined using Luminex single antigen beads, in which up to 100 different proteins are fixed simulteneously on the surface of microspheres. This method allows to determine indications for desensitization in the pre- and post-transplantation period (Akalin et al., 2008). It was also used to investigate antibodies to rare antigens. In patients with a high pre-transplantation level of donor-specific antibodies, the antibodies to donor MHC class 1 chain-related antigen A (MICA) and B (MICB) were used as biomarkers, which improved the diagnostics of acute humoral rejections (Zou et al., 2007). For possible prevention and diagnostics of cellular rejection, the interferon- gamma ELISPOT assay was shown to be efficient as a biomarker to determine alloreactivity of $\mathrm{T}$ cells. The correlation between the level of T-cells and acute rejection was demonstrated 6 and 12 months after renal transplantation (Nickel et al., 2004). The immunoadsorption blood test method in patients may also be used to individualize immunosuppressive therapy (Bestard et al., 2011). In addition, kidney biopsies can reveal the extent of inflammatory changes (Einke et al., 2010).

A significant number of biomarkers are assessed using immunoenzymometric and immunoadsorption assays, which are efficient, but have not clarified the main issue: how to achieve personalisation when transplanting organs, which is a complex multi-factor treatment method. Every body has individual reaction to the graft; the response of the body to immunosuppressive therapy, different regimens and also to doses. Each individual differs not only in immunogenetics, but also pharmacogenetics. It is possible to improve the outcomes of transplantation only by personalisation of treatment.

\section{OMICS IN TRANSPLANT MEDICINE}

The implementation of OMIC started ten years ago by using high tech in transplantation. The name neologism OMICS was coined by the use of these letters after a particular field of scientific studies in biology and medicine (for example, genomics, proteinomics, etc.). In organ transplantation, the term transplantomics is used. These studies integrate multiple gene, protein, and metabolite expression in blood, urine and allografts. A wide range of conducted studies has provided encouraging results.

To study the gene expression, the use of profile microchips (gene expression profiling, mRNA expression microarray, micro RNA) has provided new data regarding prognostication and diagnostics of acute rejection episodes. The work of M. Suthanthrian's team demonstrated an increase in gene expression in urine sediment in cases of suspected acute rejection (Anglicheau and Suthanhiran, 2008; Suthanthiran et al., 2011). Genomics methods turned out be be prospective also in the study of bioptates (Reeve et al., 2009). The efficiency of diagnostics of acute and chronic rejection of renal allografts and the opportunity to individualise immunosuppressive therapy have been demonstrated (Flechner et al., 2004; Halloran, 2010). Investigations on prognostication and early diagnostics of the extent of chronic injuries to allografts are of special interest. In long-term observation of gene expression dynamics can indicate development of interstitial fibrosis and tubular atrophy of renal allografts (Muthukumar et al., 2011). Gene technology can be used to reveal the extent of ischemia-reperfusion complications during zero-hour and one-hour biopsy of renal allografts (Mba et al., 2011), and after renal transplantation (Farid et al., 2011). Important prospects have opened up by using genomics to clarify the tolerance problem, when stable allograft function must be secured at minimum or no immunosuppression (Sagoo et al., 2011). Knowledge of gene polymorphism and expression therefore makes it possible to select patients with low immunological risk and, respectively, low immunosuppression, which is required for transplantation (Brouard et al., 2007).

A large number of studies in transplantation are focused on proteomics (Klienzl-Wagner et al., 2011). Mass spectrometry and flow cytometry methods can be used to determine the activity of proteins and polypeptides in urine, blood and allografts, which can indicate various pathological conditions. Tubulitis in renal allografts can be revealed by raised chemokine levels in the urine, an early symptom of acute rejection (Ho et al., 2011). Moreover, increase in chemokine CMP-1 levels in urine during six months after transplantation is correlated with the development of interstitial fibrosis and tubular atrophy and is the most important criterion of chronic injury of renal allografts (Ho et al., 2010). The correlation between changes taking place in 40 urine peptides and transcriptional (gene) data from puncture biopsies, and thus peptide levels could be used to indicate development of acute rejection in renal allografts. The study of proteins in a cardiac allograft showed different arrangement during acute episodes and at other times (Borozdenkova et al., 2004). Simultaneous determination of levels and arrangement of 19 proteins in urine was used to assess interstitial fibrosis and tubular atrophy, an indication for chronic allograft injury (Quintana et al., 2009). A dynamic study of the protein profile in urine can be used to diagnose the degree of ischemia-reperfusion complications (Mueller et al., 2011), non-immune injury to renal allografts (BanonManeus et al., 2010) and to carry out their differential diagnosis with BK virus nephropathy (Jahnukainen et al., 2006). Due to constant lack of organs for transplantation and the use of marginal donors, issues of preservation of organs remains and important issue. Studies have reported on means to prognosticate renal function by protein group concentra- 
THE USE OF BIOMARKERS IN PRE- AND POST-TRANSPLANTATION PERIOD FOR KIDNEY TRANSPLANTATION

\begin{tabular}{|c|c|c|}
\hline Biomarkers & Diagnostic role & Examples \\
\hline $\begin{array}{l}\text { Pre-transplant biomarkers } \\
\text { (donors) }\end{array}$ & $\begin{array}{l}\text { Acute and chronic injury of transplantable } \\
\text { organ }\end{array}$ & NGAL, KIM-1, IL-18, etc. \\
\hline \multirow[t]{2}{*}{$\begin{array}{l}\text { Pre-transplant biomarkers } \\
\text { (recipients) }\end{array}$} & Immunological risk, induction of tolerance & $\begin{array}{l}\text { Genomic analysis, mutations in the innate immune system Toll-like receptor } \\
\text { or complement factor C3, HLA and non-HLA antibodies, etc. }\end{array}$ \\
\hline & Drug nephrotoxicity & Genomic analysis \\
\hline Post-transplant biomarkers & Ischemia-reperfusion injury, acute injury, & Invasive (biopsy) and non-invasive markers (NGAL, KIM-1, IL-18, etc). \\
\hline
\end{tabular}

(dynamic) nephrotoxicity

Acute cellular and/or humoral rejection

Chronic graft dysfunction

Monitoring of graft accomodation

tions in the perfusate (Matar et al., 2011). These studies seem particularly important to us and also to all clinicians involved in kidney transplantation.

The study of the distribution of expressed genes and proteins before and after organ transplantation provides a unique opportunity to determine changes related to transplantation at a higher level than before. These studies complement each other, and there is no correlation or direct association between the RNA distribution in cells and tissues and the number of functional proteins (Tiers and Mann, 2003).

When analyzing the state of transplantation using biomarkers, it should be noted that their combined use apparently is the only opportunity to further improve outcomes of organ transplantation (Table 1). The first studies have already turned out to be prospective for the understanding of mechanisms of immune response, acute and chronic injury of allografts. However, there is currently no biomarker that can be used as a standard in the diagnostics of transplantation situations. There is a whole range of marker identification problems, from correct blood sampling and handling to adequate assessment of results. Also, it would be difficult, if not impossible, to identify only one biomarker that would be required to diagnose physiology and pathology of allografts. However, a set of biomarkers may be efficient, to create an integral criterion combining blood, urine and allograft sample tests obtained at the same time, particularly after computer processing are developed for diagnostics and personification of treatment (Roukas, 2010; Waldman and Terzic, 2011). Currently intensive research is being carried out to meet the biomarker challenges.

\section{REFERENCES}

Anonymous (2001). Biomarker definition working group. Biomarkers and surrogate endpoints: Preferred definitions and conceptual framework. Clin. Pharmacol. Ther., 69, 89-95.

Akalin, E., Dinavahi, R., Friedlander, R., Ames, S., de Boccardo, G., Sehgal, V., Schroppel, B., Bhaskaran, M., Lerner, S., Fotino, M., Murphy, B., Bromberg, J. S. (2008). Addition of plasmapheresis decreased the inci-
Invasive (biopsy with C4D staining) and non-invasive markers (FOXP3, Granzyme B, Perforin, etc).

Invasive (biopsy) and non-invasive markers (transforming growth factor-ā and connective tissue growth factor, chemokine CCL2, KIM-1, etc.)

Invasive (biopsy) and non-invasive markers (donor-specific antibodies, tolerance-associated gene-expression signatures, etc.)

dence of acute antibody-mediated rejection in sensitized patients with strong donor-specific antibodies. Clin. J. Amer. Soc. Nephrol., 3, 1160-1167.

Anglicheau, D., Suthanthiran, M. (2008). Noninvasive prediction of organ graft rejection and outcome using gene expression patterns. Transplantation, 86, 192-199.

Banon-Maneus, E., Diekmann, F., Carrascal, M., Quintana, L.F., Moya-Rull, D., Bescos, M., Ramírez-Bajo, M. J., Rovira, J., Gutierrez-Dalmau, A., Sole-Gonzalez, A., Abian, J., Campistol, J. M. (2010). Two-dimensional difference gel electrophoresis urinary proteomic profile in the search of nonimmune chronic allograft dysfunction biomarkers. Transplantation, 89, 548-558.

Bestard, O., Gruzado, J., Cassis, L., Franquesa, M., Cantarelli, C., Torras, J., Goma, M., Sawitzki, B., Volk, H., Reinke, P., Grinyo, J. (2011). Immune-monitoring of alloreactive memory/effector T-cell alloresponse for selection on CNI-free immunpsupression in renal transplantation. Amer. J. Transplant., 11, 395.

Borozdenkova, S., Westbrook, J. A., Patel, V., Wait, R., Bolad, I., Burke, M. M., Bell, A. D., Banner, N. R., Dunn, M. J., Rose, M. L. (2004). Use of proteomics to discover novel markers of cardiac allograft rejection. $J$. Proteome Res., 3, 282-287.

Brouard, S., Mansfield, E., Braud, C., Li, L., Giral, M., Hsieh, S. C., Baeten, D., Zhang, M., Ashton-Chess, J., Braudeau, C., Hsieh, F., Dupont, A., Pallier, A., Moreau, A., Louis, S., Ruiz, C., Salvatierra, O., Soulillou, J. P., Sarwal, M. (2007). Identification of a peripheral blood transcriptional biomarker panel associated with operational renal allograft tolerance. Proc. Nat. Acad. Sci USA., 104, 15448-15453.

Calabuig, A., Guirado, L., Ramos, D. (2012). Prognostic significance and diagnosis of proteinuria in renal transplantation. Transplant. Rev., 26, 30-35.

Coca, S., Yalavarthy, R., Concato, J., Parikh, C. (2008). Biomarkers for the diagnosis and risk stratification of acute kidney injury. A systematic review. Kidney Int., 73, 1008-1016.

Danovitch, G. (2010). Handbook of Kidney Transplantation, $5^{\text {th }}$ edition. Lippincott: Williams and Wilkins. $471 \mathrm{pp}$.

De Gruttola, V. G. (2001). Considerations in the evaluation of surrogate endpoints in clinical trials: Summary of the National Institutes of Health workshop. Control Clin. Trials, 22, 485-502.

Einecke, G., Mengel, M., Reeve, J., Gwinner, W., Broecker, V., Haller, H., Halloran P.F. (2010). Molecular changes in renal allograft protocol biopsies reflect a stereotyped organization in injured or inflamed sites. Amer. J. Transplant., 10 (Suppl 4), 62. 
Farid, W., Pan, Q., van der Meer, A. (2011). Hepatocyte-derived microRNA in human serum are sensitive markers for hepatic injury in liver transplantation. Amer. J. Transplant., 11 (Suppl 2), 389.

Flechner, S. M., Kurian, S. M., Head, S. R., Sharp, S. M., Whisenant, T. C., Zhang, J., Chismar, J. D., Horvath, S., Mondala, T., Gilmartin, T., Cook, D.J., Kay, S. A., Walker, J. R., Salomon, D. R. (2004). Kidney transplant rejection and tissue injury by gene profiling of biopsies and peripheral blood lymphocytes. Amer. J. Transplant., 4, 1475-1489.

Foster, C., Cooper, C. (2009). Urgent need develop independent biomarkers for functional, diagnostic and prognostic application in oncology research. Biomarkers Med., 3, 329-333.

Gillespie, A., Lee, I. (2008). Biomarkers in renal transplantation. Biomarkers Med., 2, 603-612.

Graetz, K., Inston, N., Rigg, K. (2009). The donor procedure. In: Transplantation, $4^{\text {th }}$ edition. Forsythe, J. (ed.). Saunders Ltd., Edinburgh, pp. 101-124.

Halloran, Ph. (2010). Individualizing immunosuppressive therapy: Opportunities to manage risk. Amer. J. Transplant., 10 (Suppl.1), 48.

Henderson, L., Nankivell, B., Chapman, J. (2011). Surveillance protocol kidney transplant biopsies: Their evolving role in clinical practice. Amer. J. Transplant.,11, 1570-1575.

Ho, J., Rush, D., Karpinsky, M., Storsley, L., Gibson, J., Stefura, W., Hayglass, K., Nickerson, P. (2010) Urinary MCP1 at 6 month correlates with development of interstitial fibrosis and tubular atrophy at 24 month in renal allograft. Amer. J. Transplant., 10 (Suppl 4): 60.

Ho, J., Rush, D., Bestland, J., Gao, A., Karpinsky, M., Storsley, L., Gibson, J., Nickerson, P. (2011). Validation of urinary CXCL10 as a maker of borderline, subclinical and clinical tubulitis. Amer. J. Transplant., 11 (Suppl 2), 387 .

Hollmen, M., Kyllonen, L., Inkenen, K., Lalla, M. L., Salmela, K. T. (2011). Urine neutrophil gelatinase associated lipokalin is a marker of graft recovery after kidney transplantation. Kidney Int., 79, 89-98.

Hricik, D. (2011). Primer on Transplantation, $3^{\text {rd }}$ edition. Blackwell, West Sussex: Wiley. 307 pp.

Johnson, M., Kao, W., Winkel, E. (2011). Heart transplantation. In: Primer on Transplantation, $3^{\text {rd }}$ edition. Hricik, D. (ed.). Wiley-Blackwell, West Sussex, pp. 171-204.

Jahnukainen, T., Malehorn, D., Sun, M., Lyons-Weiler, J., Bigbee, W., Gupta, G., Shapiro, R., Randhawa, P. S., Pelikan, R., Hauskrecht, M., Vats, A. (2006). Proteomic analysis of urine in kidney transplant patients with BK virus nephropathy. J. Amer. Soc. Nephrol., 17, 3248-3252.

Jushinskis, J., Amerika, D., Suhorukovs, V., Trushkovs, S., Maltsevs, A., Rozental, R. (2011). Urine NGAL as a biomarker for evaluation of deceased kidney donors. Transplant. Int., 24, 273.

Klienzl-Wagner, K., Pratschke, J., Brandacher, G. (2011). Proteomics- a blessing or curse? Application of proteomics technology to transplant medicine. Transplantation, 92, 499-509.

Loupy, A., Hill, G., Suberbielle, C., Charron, D., Anglicheau, D., Zuber, J., Timsit, M., Bruneval, P., Empans, J., Jouven, X., Legendre, C. (2011).. Significance of CD4 Banff scores in early protocol biopsies of kidney transplant recipients with preformed donor-specific antibodies (DSA). Amer. J. Transplant., 11, 56-65.

Matar, M., Nguyen, M., Aljiffry, M., Salman, A., Aikins, R., Paraskevas, S. (2011). HMGB-1 and HSP-70 in mechanically preserved kidney allograft as markers of long term function. Amer. J. Transplant., 11 (Suppl 2), 383-384

Mba, M., Maluf, D., Dumer, S., Scian, M., Posner, M., King, A., Gehr, B., Cotterell, A., Mas, R. (2011). Molecular biomarkers of human kidney transplant ischemia reperfusion injury. Amer. J. Transplant., 11 (Suppl 2), 454.

McIlroy, D., Wagener, G., Lee, H. (2010). Biomarkers in acute kidney injury: An evolving domain. Anesthesiology, 112, 998-1004.
Molnar, M., Kovesdy, C., Bunnapradist, S., Streja, E., Krishnan, M., Nisselson, A., Kalantar-Zadeh, K. (2011). Associations of pretransplant serum albumin with post-transplant outcomes in kidney transplant recipients. Amer. J. Transplant., 11, 1006-1016.

Mueller, T., Pedrycz, B., Comtson, C., Zhu, L., Andeson, C., Perkins, D., Luyckx, V. (2011). Oncostatin M and its receptors are key mediator of local and distant organ inflammation and injury after ischemia and reperfusion. Amer. J. Transplant., 11 (Suppl 2), 389.

Muthukumar, T., Mueller, F., Anglicheau, D., Sharma, V., Ding, R., Suthanthiran, M. (2011). Intragraft MicroRNA expression signatures of interstitial fibrosis and tubular atrophy of human renal allografts. Amer. J. Transplant., 10, 291.

Nankivell, B. J., Chapmen, J. R. (2006). Chronic allograft nephropathy. Current concept and future direction. Transplantation, 81, 643-654.

Nickel, P., Presber, F., Bold, G., Biti, D., Schonemann, C., Tullius, S. G., Volk, H. D., Reinke, P. (2004). Enzyme-linked immunosorbent spot assay for donor-reactive interferon-gamma-producing cells indentifies T-cell presentation and correlates with graft function at 6 at 12 month in renal-transplant recipients. Transplantation, 78, 1640-1646.

Parikh, C., Jani, A., Mishra, J., Ma, Q., Kelly, C., Barasch, J., Edelstein, C. L., Devarajan, P. (2006). Urine NGAL and IL-18 are predictive biomarkers for delayed graft function following kidney transplantation. Amer. J. Transplant., 6, 1639-1645.

Quintana, L. F., Sole-Gonzalez, A., Kalko, S. G., Banon-Maneus, E., Sole, M., Diekmann, F., Gutierrez-Dalmau, A., Abian, J., Campistol, J. M. (2009). Urine proteomics to detect biomarkers for chronic allograft dysfunction. J. Amer. Soc. Nephrol., 20, 428-435.

Reeve, J., Einecke, G., Mengel, M., Sis, B., Kayser, N., Kaplan, B., Halloran, P. (2009). Diagnosing rejection in renal transplants: A comparison of molecular and histopathology-based approaches. Amer. J. Transplant., 9, 180-1810.

Roukos, D. (2010) Next generation, genome sequencing based biomarkers: Concerns and challenges for medical practice. Biomarkers Med., 4, $583-586$.

Sagoo, P., Perucha, E., Sawitzki, B., Tomiuk, S., Stephens, D. A., Miqueu, P., Chapman, S., Craciun, L., Sergeant, R., Brouard, S., Rovis, F., Jimenez, E., Ballow, A., Giral, M., Rebollo-Mesa, I., Le Moine, A., Braudeau, C., Hilton, R., Gerstmayer, B., Bourcier, K., Sharif, A., Krajewska, M., Lord, G. M., Roberts, I., Goldman, M., Wood, K. J., Newell, K., Seyfert-Margolis, V., Warrens, A. N., Janssen, U., Volk, H. D., Soulillou, J. P., Hernandez-Fuentes, M. P., Lechler, R. I. (2010). Development of a crossplatform biomarker signature to detect renal transplant tolerance in humans. J. Clin. Invest., 120, 1848-1861.

Shand, J. A., Menown, I. B., McEneaney, D. J. (2010). A timely diagnosis of myocardial infarction. Biomarkers Med. ,4, 385-393.

Snanoudj, R., Royal, V., Elie, C., Rabant, M., Girardin, C., Morelon, E., Kreis, H., Fournet, J. C., Noel, L. H., Legendre, C. (2011). Specificity of histological markers of long term CNI nephrotoxicity in kidney transplant recipient under low-dose cyclosporine therapy. Amer. J. Transplant., 11, 2635-2646.

Sprangers, B., Kuypers, D., Vanrenterghem, Y. (2011). Immunosupression: Does one regimen fit all. Transplantation, 93, 251-261.

Stock, P., Kirk, A. (2011). The risk and opportunity of homeostasis repopulation. Amer. J. Transplant., 11, 1349-1350.

Suthanthiran, M., Ding, R., Sharma, V., Abecassis, M., Samstein, B., Knechtle, S., Hascock, W., Han, L., Liu, J., Shaked, A. (2011). Urinary cell messenger RNA expression signatures anticipate acute cellular rejection. Amer. J. Transplant., 11 (Suppl 2), 29.

Tyres, M., Mann, M. (2006). From genomics to proteomics. Nature, 422, 193-196.

Vasan, R. S. (2006). Biomarkers of cardiovascular disease: Molecular basis and practical considerations. Circulation, 113, 2335-2362. 
Waikar, S., Betensky, R., Emerson, S., Bonventre, J. (2012). Imperfect gold standards for kidney injury biomarker evolution. J. Amer. Soc. Nephrol., 23, 13-21.

Received 22 March 2012
Waldman, S., Terzic, A. (2011). Patient-centric clinical pharmacology advances the path to personalized medicine. Biomarkers Med., 5, 607-700.

Zou, Y., Stastny, P., Susal, C., Dohler, B., Opelz, G. (2007). Antibodies against MICA antigens and kidney-transplant rejection. New Engl. J. Med., 357, 1293-1300.

\section{BIOMARKIERI UN TO IESPĒJAMAIS LIETOJUMS TRANSPLANTĀCIJĀ}

Raksts veltīts literatūras apskatam par divām aktuālām mūsdienu medicīnas tēmām: transplantoloğiju un biomarkiieriem. Sasniegtas pirmās sekmes imūnfermentatīvo un imūnsorbcijas metožu izpētē dažādu transplantolog̣ijas klīnikā sastopamo situāciju izvērtēšanā. Tomēr šīs metodes nespēj atrisināt sarežğîtākas un neskaidras problēmas transplantoloğijā, tādas kā tolerance, ārstēšanas personifikācija utt. Šajā sakarā tiek piedāvāti pirmie rezultāti no perspektīviem pētījumiem, izmantojot OMIC metodes: genomika, proteinomika u.c., kurus apvieno kopējais jēdziens — transplantomics. 
Review

\title{
STRESS RESPONSE TO SURGERY AND POSSIBLE WAYS OF ITS CORRECTION
}

\author{
Igors Ivanovs, Māris Mihelsons, and Viesturs Boka
}

Surgery Department, University of Latvia, Šarlotes iela 1a, Rīga, LV-1001, LATVIA;

dr.igors.ivanovs@gmail.com

Communicated by Vija Kluša

The stress response to surgery has two main systemic effects in an organism: neuroendocrine and haemato-immunological. Neuroendocrine effects are induced by changes in the hypothalamic-pituitary-adrenal axis and the sympathetic-adrenal-medullary axis. Haematoimmunological effects are characterised by cytokine production, acute phase reaction and lymphocyte and neutrophil proliferation. All of these responses interact closely. Prolongation of the stress response can increase morbidity and worsen postoperative outcome. Surgical stress can be affected by preoperative, perioperative and postoperative factors. In this paper, we review the main neuroendocrine and haemato-immunological changes related to stress and discuss different possible approaches to minimise the stress response to surgery.

Key words: stress response to surgery, neuroendocrine response, haemato-immunological response, ways to decrease stress.

\section{INTROUCTION}

Faster and better postoperative recovery is an important goal of modern surgery. In the early postoperative period, pain and stress are the most common problems (Wu et al., 2003; Ledowski et al., 2005; Ahonen et al., 2007; Jokela et al., 2007; Wiley W. Souba, 2007). Systemic response to injury or infection involves cell signaling, cell migration, and mediator release. Minor host insults instigate a local inflammatory response that is transient and in most cases beneficial. Major host insults may propagate reactions that can become amplified, resulting in systemic inflammation and potentially detrimental responses (Souba et al., 2007; Brunicardi, 2010). Stress response to surgery is a compensatory mechanism, but it has been argued that this response is unnecessary in current surgery. If the stress response is prolonged, it results in decreased disease resistance, increased morbidity and longer hospitalisation (Kehlet, 1997; Deborah et al., 2004; Brunicardi, 2010). The stress response to surgery includes a wide range of hormonal and metabolic changes, among which two main systemic effects - the neuroendocrine and the haemato-immunological effects can be distinguished (Desborough, 2000).

\section{THE NEUROENDOCRINE RESPONSE TO SURGERY}

The central nervous system (CNS) plays a key role in orchestrating the inflammatory response. The CNS influences multiple organs through both neurohormonal and endocrine signals (Brunicardi, 2010). The neuroendocrine response to surgery is characterised by two main pathways: the hypothalamic-pituitary-adrenal axis (HPA) and the sympathetic-adrenal-medullary (SAM) axis (Elenkov et al., 2000; Segerstrom et al., 2004; Miller et al., 2007). In the HPA axis, activation is initiated during stress at the paraventricular nucleus of the hypothalamus, which secretes releasing hormones (RHs). The hypothalamic releasing hormones control the pituitary gland. The hypothalamus also exerts direct neural control over the posterior pituitary gland (Lyons et al., 1997).

The anterior pituitary gland synthesises six main hormones: corticotropin, somatotropin, prolactin, thyrotropin, follitropin and lutropin. Corticotropin, somatotropin and prolactin secretion are increased under stress. The concentrations of the other anterior pituitary hormones are not changed markedly during surgical stress. The major role in the stress response to surgery is played by corticotropin. Corticotropin promotes cortisol production in the adrenal cortex. Cortisol secretion increases several minutes after surgery, and the cortisol concentration reaches a maximum at approximately 4-6 hours after surgery, depending on the severity of the surgical trauma (Desborough, et al., 1993; Nicolson et al., 1998). A feedback mechanism operates so that the increased concentrations of circulating cortisol inhibit the secretion of corticotropin by the pituitary gland, but this mechanism appears to be ineffective after surgery, and concentrations of both hormones remain high. Cortisol promotes protein 
breakdown and gluconeogenesis in the liver as well as inhibits the use of glucose by cells. These effects lead to an increased blood glucose concentration (Desborough, 2000).

Somatotropin has an important role in growth regulation and in the cell's metabolic processes. This hormone stimulates protein synthesis and glycogenolysis, promotes lipolysis, inhibits protein breakdown and has an anti-insulin effect. The concentration of somatotropin increases after surgery in proportion to the severity of the injury (Desborough et al., 1999). Somatotropin inhibits glucose uptake and use by cells (Grainne, et al. 2005). Prolactin secretion increases as a part of the stress response to surgery. Prolactin stimulates milk secretion from the breast and has a slight metabolic influence during the stress response (Desborough, et al., 1999).

Another pituitary hormone is thyrotropin. The thyrotropin concentration may be slightly decreased during the first two hours after surgery and then return to the preoperative level. The target organ of thyrotropin is the thyroid gland, which produces the thyroid hormones thyroxine (T4) and triiodothyronine (T3). These hormones are bound to their binding proteins, albumin, thyroxine-binding pre-albumin and thyroid-binding globulin. The free thyroid hormones in the plasma are metabolically active (Edwards, 1997). Thyroid hormones stimulate the oxygen consumption of most of the metabolically active tissues of the body. As a result, cell metabolism and heat production increase. The concentrations of the thyroid hormones may decrease slightly after surgery and return to normal in several days. These changes may appear because of the close relationship between thyroid hormones, catecholamines and cortisol. Exogenous steroids suppress T3 and T4; thus, hypercortisolaemia after surgery may also depress the thyroid hormone levels (Croizer et al., 1997; Desborough, 1999).

Follitropin and lutropin are also secreted from the anterior pituitary gland. In females, follitropin is responsible for the development of the ovarian follicles, and lutropin promotes the maturation of these follicles. In males, follitropin maintains the spermatic epithelium, and lutropin stimulates the testis cells. The follitropin and lutropin plasma concentrations show variable changes after surgical stress (Desborough et al., 1999, Tilbrook et al., 2002).

Vasopressin, or arginine vasopressin, is secreted from the posterior pituitary. Vasopressin has effects on the kidneys and increases water absorption in the collecting ducts of the nephron. These effects support the preservation of adequate body fluid volumes. Vasopressin also has an endocrine function, acting with corticoliberin to stimulate the secretion of pro-opiomelanocortin from the anterior pituitary (Grainne et al., 2005). The vasopressin concentration increases in response to surgical stress (Desborough et al., 1999).

In the SAM axis, activation involves preganglionic sympathetic nervous system neurons that descend from nuclei in the brain. The release of the neurotransmitter acetylcholine from these neurons in the adrenal medulla stimulates cells to secrete adrenaline. The post-ganglionic sympathetic nervous system fibres, however, predominantly secrete noradrenaline. Therefore, activation of the SAM mainly leads to the release of both adrenaline and noradrenaline (Elenkov et al., 2000). The above-mentioned processes lead to the well-recognised cardiovascular effects of tachycardia and hypertension. In addition, the functions of the liver, pancreas, kidney and immune system are directly modified by efferent sympathetic stimulation (Elenkov et al., 2000; Sanders and Kavelaars, 2007). Pancreatic secretion is also altered in response to surgical stress: glucagon secretion is activated and insulin secretion is diminished. The decreased insulin concentration may be caused partially by the inhibition of pancreas $\beta$-cell secretion. There is also a failure of the typical cellular response to insulin, the so-called "insulin resistance".

The plasma glucagon concentration increases transiently after surgery (Desborough, 2000; Grainne et al., 2005). Glucagon promotes hepatic glycogenolysis and gluconeogenesis and increases the glucose concentration in the blood. Other stress hormones, such as cortisol and catecholamines, also facilitate glucose production as a result of increased hepatic glycogenolysis and gluconeogenesis. These factors cause the glucose concentration in the plasma to increase as a response to stress after surgery, and they are related to the intensity of the surgical injury. For example, in cardiac surgery, blood glucose concentrations increase up to 10-12 $\mathrm{mmol} / \mathrm{l}$ and remain elevated for $24 \mathrm{~h}$ after surgery (Anonymous, 1998; Grainne et al., 2005). The overall metabolic effects of the hormonal changes are the following: increased catabolism, which mobilises substrates to provide energy sources, and a mechanism to retain salt and water, thus maintaining fluid volume and cardiovascular homeostasis (Desborough et al., 1999).

\section{THE HAEMATO-IMMUNOLOGICAL RESPONSE TO SURGERY}

The immune system has developed to respond to and neutralize pathogenic micro-organisms as well as coordinate tissue repair. Systemic inflammation is characterised by exaggerated immune responses to either a sterile or infectious process. The cause of inflammatory activation needs to be addressed to resolve the dysregulated immune state (Brunicardi, 2010). Recent years show that surgery and anaesthesia exert an immunosuppressive effect (Ogawa et al., 2000, Zura et al., 2009, Veenhof et al., 2012). Both innate and adaptive immune functions are depressed (Brand et al., 2003; Franke et al., 2006; Zura et al., 2009). It has been shown that the immune response is altered with respect to phagocyte compromise, lymphocyte transformation, cytotoxicity, antibody response and the chemotactic functions of immune cells (Buunen et al., 2004; Bengmark, 2006; Golubovska et al., 2008). The balance between pro-inflammatory and anti-inflammatory processes is important. 
Cytokines play a major role in the regulation of the immune response to surgery. Cytokines are a group of small cellsignalling proteins that are essential for both the innate and the adaptive immune responses. Cytokines are produced mostly from activated leucocytes, monocytes, fibroblasts and endothelial cells as an early response to tissue injury. However, virtually all nucleated cells are potent producers of cytokines. Cytokines act on surface receptors on many different target cells, and they change protein synthesis within cells. Cytokines mediate a broad sequence of cellular responses, including cell migration, DNA replication, and immunocyte proliferation (Brunicardi, 2010). More than 50 cytokines are known. After surgery, the main cytokines released are interleukin-1 (IL-1), interleukin-6 (IL-6), and tumour necrosis factor. IL-6 is the main cytokine responsible for inducing the systemic changes known as the acute-phase response.

The changes that occur after surgery and tissue damage are known as the acute-phase response. These changes are the following: fever, leucocytosis, production of acute-phase proteins in the liver and changes in the serum concentrations of transport proteins. The combination of leucocytosis with neutrophilosis is one of the immunological effects of inflammation. Neutrophils are normally found in the blood stream. Neutrophilosis occurs during the acute phase of inflammation, particularly as a result of bacterial infection, environmental exposure, or surgical trauma. Neutrophils are one of the first-responders among the inflammatory cells to migrate towards the site of inflammation (Nathan, 2006). They migrate through the blood vessels and interstitial tissue, following chemical signals such as interleukin-8 (IL-8) and leukotriene B4. Neutrophils are recruited to the site of injury within minutes following trauma and are the hallmark of acute inflammation (Witko-Sarsat et al., 2000; Nathan, 2006).

Another important part of the acute-phase response to surgical trauma is the production of acute-phase proteins in the liver, such as C-reactive protein (CRP), fibrinogen, $\alpha 2$-macroglobulin and others. These proteins act as inflammatory mediators (Sheeran et al., 1997). The physiological role of CRP is to bind to phosphocholine expressed on the surface of dead or dying cells to activate the classical pathway of the complement system via the C1Q (a subcomponent of $\mathrm{C} 1$ complement) complex. CRP enhances phagocytosis by macrophages. Thus, CRP participates in the clearance of necrotic and apoptotic cells. CRP also plays an important role in immunity as a defence system against infections (Pepys et al., 2003). In the acute- phase response, the levels of CRP increase rapidly within two hours of surgical trauma, reaching their peak during a period of 2-4 days afterwards. Upon the resolution of the acute-phase response, CRP declines with a relatively short half-life of 18 hours. Measuring the CRP level is a screen of postoperative inflammation. Rapid, marked increases in CRP occur with inflammation, infection, trauma and tissue necrosis. The half-life of CRP is constant, and therefore, its level is mainly determined by the rate of production and the sever- ity of trauma. Researchers have shown that the CRP concentration in the plasma is the main predictive factor of worse physical condition after surgery (Hall et al., 2002).

\section{BIDIRECTIONAL NEURO-IMMUNE COMMUNICA- TION}

The haemato-immune and neuroendocrine systems interact closely, and one system influences the other during the stress response in a bidirectional regulatory circuit (Fig. 1). This regulation has been shown to be mediated in part through hormones and cytokines. Both systems have receptors for both types of signalling molecules (Elenkov et al., 2000; Segerstrom et al., 2004; Miller et al., 2007). The two main neuroendocrine pathways are the HPA and the SAM axis. Many hormones from these endocrine pathways have also been shown to be produced by, and have activity on, lymphocytes. Examples include corticoliberin, somatotropin, prolactin, thyrotropin, vasopressin and others (Smith, 2008). The catecholamines (adrenaline and noradrenaline) can also influence immune cells, as all leukocytes express adrenergic surface receptors (Smith, 2008).

Glucocorticoids have immunosuppressive properties. Immunologic changes associated with glucocorticoids include thymic involution, depressed cell-mediated immune responses reflected by decreases in T-killer and natural killer cell function, T-lymphocyte blastogenesis, mixed lymphocyte responsiveness, graft-versus-host reactions, and delayed hypersensitivity responses. Glucocorticoids inhibit neutrophil superoxide reactivity, suppress chemotaxis, and normalise apoptosis signalling mechanisms, but maintain neutrophil phagocytic function. (Brunicardi, 2010). In addition, post-ganglionic nerve fibres directly innervate lymphoid organs, including the thymus, spleen, lymph nodes and bone marrow, and influence the production and functions of immune cells (Elenkov et al., 2000; Krüger et al., 2007).

\section{WAYS TO DECREASE THE STRESS RESPONSE TO SURGERY}

Among the many factors that can influence the stress response to surgery, we can distinguish three main groups: preoperative factors, perioperative factors, and postoperative factors.

\section{The preoperative factors}

Psychological stress, anxiety and emotions. Fear, anxiety, and psychological threat of danger in the preoperative period can significantly reduce tolerance to pain and stress (Tewes, 1999). It is known that the initiation of the stress response is governed by a person's ability to cope with a particular stimulus. Therefore, psychological stress occurs when a person's ability to "cope" with a situation is exceeded (Wetsch, 2009). The stimuli pass to the limbic system in the region of the amygdala and hippocampus and to the posterior hypothalamus. Stimulation of the latter influ- 


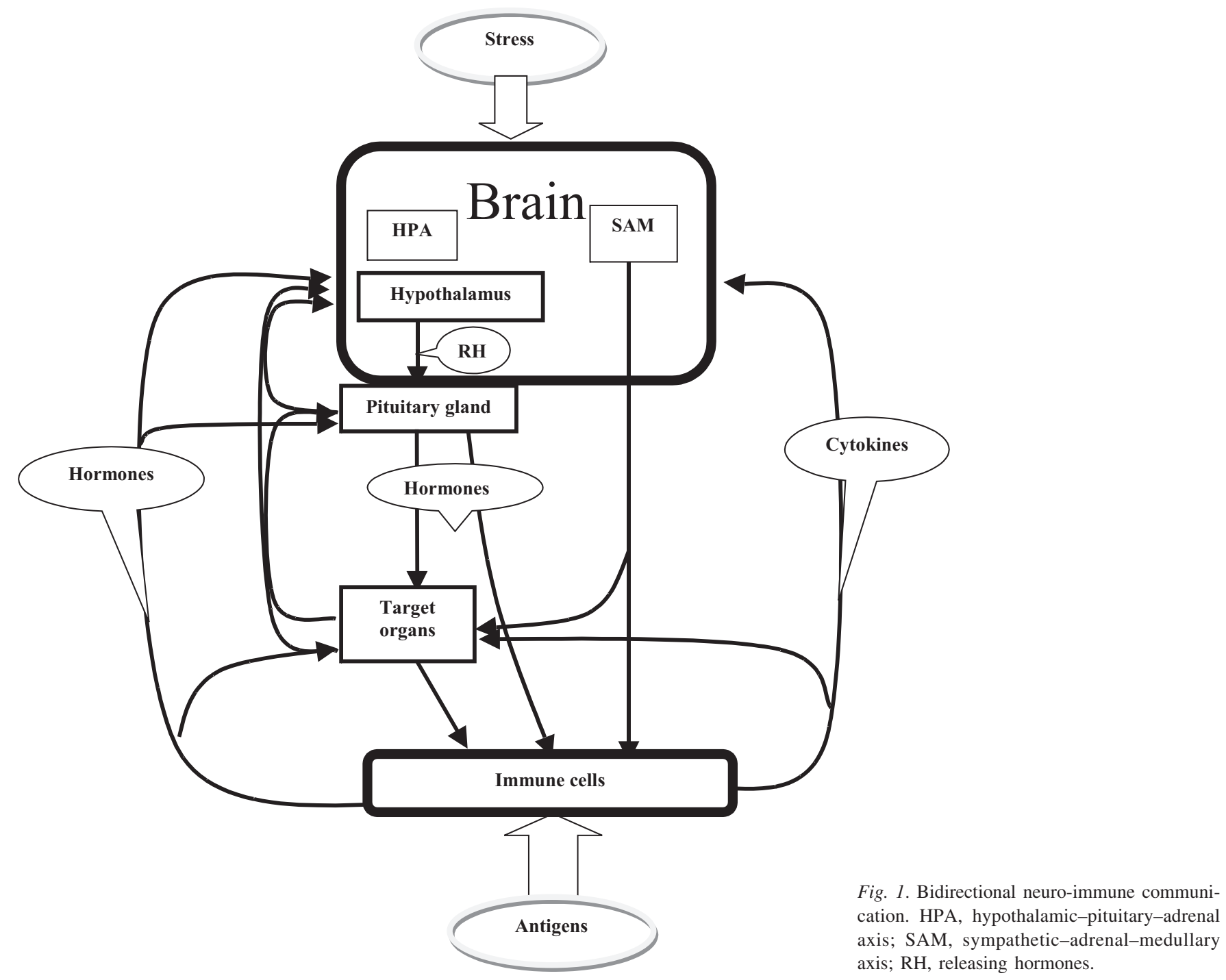

ences pituitary functions and provokes stress-related changes in an organism.

Ways to decrease the stress. To decrease anxiety in preoperative periods, we can use adequate patient management and preoperative teamwork. An important factor in decreasing preoperative stress is the preoperative educational conversation. Patients are given information about the operation, analgesia, postoperative course, prognosis, etc. (Kitching et al., 2009). Consideration should be directed to appropriate premedication therapy: anxiolytics, such as benzodiazepines, are the most popular medication for reducing fear and anxiety; additionally, painkillers such as COX-2 inhibitors can be used as a preemptive analgesia before surgery to reduce the pain and opioid requirements during the operation (Puura et al., 2006). COX-1 inhibitors are less advisable for preemptive analgesia because of antithrombotic effect and irritation of gastric mucosa, which can cause ulceration and bleeding in postoperative period. There is also an increasing interest in using $\beta$-blockers; these drugs can suppress the surgical induction of catecholamines and $\alpha_{2}$-agonists (e.g., clonidine), which can have an opioidsparing effect and reduce myocardial ischaemia (Kitching et al., 2009).
Preoperative fasting and fluid balance. Traditionally, patients for elective surgery are fasted overnight to reduce the aspiration risk; however, this practise can lead to dehydration. The reduction in the effective circulating volume is sensed by the pressure-sensitive baroreceptors in the aorta, carotid and renal arteries. Proportional to the magnitude of the volume loss, the pituitary gland is activated, and stress hormones are released (Manorama, 2003). Starvation also stimulates catabolic processes and perioperative stress.

Ways to decrease the stress. Recent guidelines have recommended a shift in fasting policy from the standard "nothing by mouth after midnight" approach to more relaxed policies that permit a period of restricted fluid intake up to two hours before surgery (Scarlett et al., 2002). Permission for clear fluid intake up to two hours preoperatively does not result in a clinically important difference in the risk of regurgitation and aspiration and can reduce perioperative stress (Grocott, 2005; Stuart, 2006). The appropriate preoperative fluid therapy with a sufficient amount of glucose is essential for maintaining the fluid balance and calorie requirement to avoid undue catabolism and decrease postoperative nausea, vomiting and pain (Maharaj, et al., 2005; Chaudhary et al., 2008). 


\section{The perioperative factors}

Anaesthesia. The specialty of anesthesia is no longer limited to the operating room. It is natural that anesthesiology, born out of the quest to relieve pain, gave rise to the field of acute and chronic pain medicine. The anesthesiologist consulting on the acute pain service may recommend oral, IM, or IV analgesia with a variety of agents, or patient-controlled analgesia (Brunicardi, 2010). Anaesthetic management depends on patient age, sex, concomitant diseases, previous medical therapy, etc. and should be tailored to each patient. General anaesthesia limits the perception of sensations during surgery but has little effect on the stress response to surgery, except for high-dose opioid anaesthesia, which may inhibit intra- but not postoperative catabolic hormonal changes (Golubovska et al., 2008). It has been suggested that even deep general anaesthesia cannot completely block the hypothalamic reaction to the noxious stimuli from an operation field.

There are differences between the two main types of general anaesthetic: inhalational and intravenous. Inhalational anaesthetics (e.g., isoflurane) have been associated with greater inflammatory response and suppression of lymphocyte functions, which can lead to greater immune suppression morbidity in the postoperative period (Karabiyik et al., 2001; Matsuoka et al., 2001). Intravenous anaesthetics have different effects on stress: ketamine may play a role in reducing postoperative pain and stress when used in addition to opioids and local anaesthetics (Tverskoy at al., 1996; Menigaux et al., 2000); in contrast, propofol promotes the inflammatory response, deepens immune suppression and supports bacterial proliferation (Bowdle et al., 2002; Golubovska et al., 2008); benzodiazepines (e.g., midazolam) suppress cortisol responses to abdominal surgery; and opioids in high doses suppress the stress response and promote surgery-induced immune suppression. However, in upper abdominal surgery, opioids are ineffective in preventing the stress response to surgery (Desborough, 2000).

Ways to decrease the stress. The use of anaesthetics with greater influence on surgical stress and a combination of intravenous and inhaled drugs is a reasonable option to decrease stress, although many intravenous and inhaled anaesthetics in normal doses have minor effects on the endocrine and metabolic functions (Lin et al., 1999; Velikovic et al., 2002; Manorama, 2003). Appropriate anaesthetic dosage is an important option for decreasing the stress response to surgery. Inadequate drug titration during anaesthesia may result in light or deep anaesthesia. During light planes of anaesthesia, feelings of pain, inadequate sleep, amnesia or muscle relaxation result in stress response. The careful titration of inhaled anaesthetic drugs and intravenous anaesthetics and the use of cardio-stable muscle relaxants are helpful to maintain adequate depth. The continuous infusion of anaesthetic drugs has proven to be excellent for preventing fluctuations in the depth of anaesthesia (Manorama, 2003).

Another way to decrease the stress response to surgery is to use local anaesthetics. The common characteristic of local anaesthetics is a reversible block of the transmission of neural impulses when placed near a nerve membrane. The neural block decreases the activation of HPA and SAM and decreases neurogenic inflammation (Coderre et al., 1993; Golubovska et al., 2008). Local anaesthetics have direct effects on endocrinal and metabolic responses. For example, extensive epidural anaesthesia with local anaesthetics can prevent the endocrine and metabolic responses to surgery in the pelvis and on the lower limbs (Desborough, 2000; Kawasaki et al., 2007). It is also assumed that local anaesthetics should decrease postoperative pulmonary complications and thromboembolic complications and improve pulmonary functions (Pöpping et al., 2008). The use of local anaesthesia improves gastrointestinal functions in the postoperative period and can decrease paralytic ileus following abdominal operations (Steinbrook, 1998). Local anaesthetics may also have systemic anti-inflammatory effects and decrease CRP and IL-6 (Hollmann et al., 2000, Bagry et al., 2008). The usage of local anaesthetics during surgery can be recommended to decrease stress-related changes.

If it is necessary to perform an operation under general anaesthesia, the combination of general anaesthetics with local anaesthetics is one of the possible options. The preemptive local anaesthesia is particularly effective when the neuronal block is performed before nociceptive stimuli are triggered. Recent studies show that this combination can decrease neuroendocrine changes related to intraoperative stress and can decrease postoperative pain (Manorama, 2003; Barczynsk et al., 2006). For example, general anaesthesia supplemented with epidural analgesia in hip replacement and abdominal surgery certainly reduces the circulatory, hyperglycaemic responses due to the inhibition of cortisol and the catecholamines (Velikovic et al., 2002).

Methods of surgical intervention. Surgery is an injury created for the purpose of treatment. The inflammatory component of the stress response depends on the extent of the injury. Procedures of short duration or abdominal laparoscopic surgeries requiring small incisions and minimal tissue handling evoke only a slight response. After laparoscopic operations, the increase in the concentrations of biochemical markers of inflammation (IL-6, CRP etc.) is not as great as after open surgery (Hollmann et al., 2000). However, the classical stress responses (cortisol, glucose, etc.) to abdominal surgery, such as cholecystectomy, are not changed greatly by reducing surgical trauma (Velickovic et al., 2002; Manorama, 2003). This observation suggests that the stimuli for the stress response arise from visceral and peritoneal afferent nerve fibres in addition to those from the abdominal wall.

Ways to decrease stress. The use of minimally invasive surgical techniques is generally associated with reduced pain and shorter hospital stays compared with open techniques. The appropriate usage of minimally invasive surgical techniques is a considerable option to decrease the inflammatory component of stress response and facilitate early discharge. 
Perioperative fluid and temperature management. Haemodynamic changes during endotracheal intubation, skin incision, and surgical manipulation provoke the secretion of stress hormones and activate HPA and SAM. Additionally, changes in the core temperature are sensed by the pre-optic area of the hypothalamus, which induces the secretion of stress hormones. Mild hypothermia $\left(35-36^{\circ} \mathrm{C}\right)$ is associated with adverse outcomes, including impaired drug metabolism, prolonged recovery from anaesthesia, cardiac morbidity, coagulopathy, wound infections, and postoperative shivering (Insler et al., 2006). The administration of cold fluids (i/v fluids, intraabdominal irrigation), large uncovered skin incisions, and internal redistribution of body heat cause body hypothermia.

Ways to decrease stress. It is essential to prevent any haemodynamic changes during surgery. The administration of $\mathrm{i} / \mathrm{v}$ fluids to avoid dehydration, maintain an effective circulating volume and prevent inadequate tissue perfusion should be considered to be a core element of perioperative management. A number of clinical studies support the notion that an approach based on administering fluids to achieve maximal left ventricular stroke volume (while avoiding excess fluid administration and consequent impairment of left ventricular performance) may improve outcomes (Grocott et al., 2005). The maintenance of constant core temperature also plays an important role in the perioperative period. Core temperature can be influenced by room temperature and body temperature. Control of body temperature can be achieved by different methods, such as perioperative warming of the patient, airflow blankets during the operation, localised heat therapy, the administration of warm fluids (i/v and intra-abdominally) and blood warmers (Scherer, 1997).

\section{Postoperative factors}

Pain management. Surgical pain is caused by inflammation from tissue trauma (surgical incision, dissection, or burns) or direct nerve injury (nerve transaction, stretching, or compression). Both factors activate HPA, SAM, and the stress response.

Ways to decrease stress. Effective postoperative analgesia is an essential factor for decreasing surgical stress. Absolute pain relief is a "gold standard" for preventing the protein breakdown and minimising endocrine and metabolic changes to the stress response (Velickovic et al., 2002). Pain relief can be achieved using different medications, including opioids (e.g., morphine), non-steroidal anti-inflammatory drugs (NSAIDs), local anaesthetics (e.g., lidocaine) and coanalgesic drugs (e.g., $\alpha_{2}$-agonists and anticonvulsants). The major goal in the management of postoperative pain is minimising the dose of medications to diminish side effects while still providing adequate analgesia. To achieve this goal, modern surgery uses a multimodal approach. The principle of the multimodal approach is to obtain good analgesic effect from different sources. This practise maximises the analgesic effect and minimises side effects, such as ileus, nausea, and sedation, especially those of opioids (Kitching et al., 2009). There is evidence that postoperative analgesia in combination with local anaesthetics is associated with a faster resolution of postoperative ileus and stimulates bowel motility. Additionally, the best option is to use different combinations of local anaesthetics, non-steroidal anti-inflammatory drugs, coanalgesics and opioids. When using such an approach, the need for opioids should be reduced (Rigg et al., 2002; Kitching et al., 2009).

Postoperative environment and nutrition. The other important factor is the environment in which a patient is situated after the operation. Behavioural and subjective changes are a part of the response to surgery. Feelings of malaise and postoperative fatigue have a strong influence on recovery from surgery and return to work (Salmon et al., 1997).

Ways to decrease stress. Postoperative fatigue and feeling of malaise is a complex multifactorial issue and can be decreased in a number of ways including early mobilisation, the avoidance of sleep disturbance, and early enteral nutrition. Such an "intensive" approach can be rewarded by early discharge from the hospital (Kehlet, 1999). The goal of nutritional support in the surgical patient is to prevent or reverse the catabolic effects of disease or injury. Factors that influence the choice of enteral formula include the extent of organ dysfunction (e.g., renal, pulmonary, hepatic, or gastrointestinal), type of operation (e.g. gastrointestinal, orthopaedic etc.), the nutrients needed to restore optimal function and healing (Brunicardi, 2010). Early enteral nutrition is an essential factor in postoperative recovery. Fears of postoperative ileus and the integrity of the newly constructed anastomosis have led to treatment typically entailing starvation with administration of intravenous fluids until the passage of flatus. However, it has since been shown that prompt postoperative enteral feeding in patients undergoing gastrointestinal resection is both effective and well tolerated even when started within 12 hours of surgery. Enteral feeding is also associated with specific clinical benefits such as reduced incidence of postoperative infectious complications and an improved wound healing response (Kitching et al., 2009). Postoperative nausea, vomiting and paralytic ileus should be avoided, and enteral or oral feeding should be used.

Bowel stimulation and enteral nutrition with a probioticsenhanced formula could be used. The term probiotic refers to "live microorganisms which when administered in adequate amounts confer a health benefit on the host" (Gorbach, 2000). The microorganisms most frequently used as probiotic agents are lactic acid bacteria (species of Lactobacillus, Enterococcus, and Bifidobacterium) and nonpathogenic antibiotic-resistant, ascosporic yeasts, especially Saccharomyces boulardii (Alvarez-Olmos et al., 2001). Probiotics have well-known effects on bowel motility, postoperative ileus, immune system and bowel microbiota (Freitas et al., 2003; Kraehenbuhl et al., 2004). The postoperative use of probiotics is another possible option to decrease the effects of stress response to surgery and decrease complications after surgery (Ivanovs et al., 2006). Probiotics stimulate the proliferation of enterocytes 
(Ishikawa et al., 1999), change the immune activity in gut-associated lymphoid tissue and decrease the proliferation of pathogenic flora in the bowel (Niers et al., 2004). Recent studies show stimulating effects of probiotics on immunoglobulin secretion (Macpherson et al., 2004). Probiotics have positive effects on leucocyte proliferation and cytokine secretion. This is especially important in postoperative stress, when both innate and adaptive immune functions are depressed and when the balance between proinflammatory and anti-inflammatory processes is impaired (Hart et al., 2004). Many studies have shown that different species of probiotic bacteria have different actions; therefore, it is better to use probiotics that contain multiple bacterial species and different probiotic bacteria to achieve the best result from probiotic therapy (Timmerman et al., 2004; Marc et al., 2005).

\section{CONCLUSION}

The stress response to surgery comprises a number of changes initiated by the neuronal activation of the hypothalamic-pituitary-adrenal axis and sympathetic-adrenalmedullary axis. The two main systemic changes are in the neuroendocrine and haemato-immune systems. Both of these systems have close interactions and influence one another. We can distinguish three main possible ways to decrease the stress response to surgery:

1. In the preoperative period, the use of adequate preoperative assessment; appropriate teamwork with a patient; educational conversation; and minimising preoperative starvation and fluid restrictions.

2. In the perioperative period, using appropriate general anaesthetics; wider use of local anaesthetics, especially in combination with general anaesthetics; minimising operative trauma; thorough intraoperative fluid management to avoid intraoperative hemodynamic changes and maintaining constant body temperature.

3 . In the postoperative period, effective postoperative analgesia using a multimodal approach, appropriate postoperative environment, early postoperative mobilisation, early enteral nutrition and probiotic use.

The appropriate use of these strategies can decrease the stress response to surgery and facilitate patient recovery.

\section{RFERENCES}

Ahonen, J., Jokela, R., Uutela, K., Huiku, M. (2007). Surgical stress index reflects surgical stress in gynaecological laparoscopic day-case surgery. Brit. J. Anaesth., 98 (4), 456-461.

Alvarez-Olmos, M., Oberhelman, R. (2001). Probiotic agents and infectious diseases: A modern perspective on a traditional therapy. Clin. Infect. Dis., 32, 1567-1576.

Anonymous (1998). Effect of intensive blood-glucose control with sulphonylureas or insulin compared with conventional treatment and risks of complications in patients with type 2 diabetes. UKPDS group. Lancet, 352, 837-853.
Bagry, H., de la Cuadra Fontaine, J. C., Asenjo, J. F., Bracco, D., Carli, F. (2008). Effect of a continuous peripheral nerve block on the inflammatory response in knee arthroplasty. Reg. Anest. Pain Med., 33 (1), 17-23.

Barczynski, M., Konturek, A., Herman, R. M. (2006). Superiority of preemptive analgesia with intraperitoneal instillation of bupivacaine before rather than after the creation of pneumoperitoneum for laparoscopic cholecystectomy: A randomized, double-blind, placebo-controlled study. Surg. Endoscopy, 20 (7), 1088-1093.

Bengmark, S. (2006). Bioecological control of inflammation and infection in critical illness. Anest. Clin. North Amer., 24, 325-337.

Benschop, R. J., Rodriguez-Feuerhahn, M. (1996). Catecholamine induced leukocytosis: Early observations, current research, and future directions. Brain Behav. Immun., 10, 77-91.

Borgdorff P. J., Ionescu, T. I., Houweling, P. L., Knape, J. T. A. (2004). Large-dose intrathecal sufentanil prevents the hormonal stress response during major abdominal surgery: A comparison with intravenous sufentanil in a prospective randomized trial. Anesth. Analg, 99 (4), 1114-1120.

Bowdle, A., Hines, R. (2002). Guest editor introduction: Pharmacology up-date 2002 seminars in anaesthesia. Perioper. Med. Pain, 11, 247-257.

Brand, J.-M., Frohn, C., Luhm, J., Kirhner, H., Schmucker, P. (2003). Early alterations in the number of circulating lymphocyte subpopulation and enchanced proinflammatory immune responce during opioid-based general anaesthesia. Shock, 20 (3), 213-217.

Brunicardi, F. C. (2010). Schwartz's Principles of Surgery. $9^{\text {th }} e d$. The McGraw-Hill Companies, Inc. USA. 1866 pp.

Buunen, M., Gholghesaei, M., Veldkamp, R., Maijer, D. W., Bonjer, H. J., Bouvy, N. D. (2004). Stress response to laparoscopic surgery: A review. Surg. Endosc., 18 (7), 1022-1028.

Chaudhary, S., Sethi, A. K., Motiani, P., Adatia, C. (2008). Pre-operative intravenous fluid therapy with crystalloids or colloids on post-operative nausea \& vomiting. Indian J. Med. Res., 127, (6), 577-581.

Chumbley, G. M., Hall, G. M. (1997). Recovery after major surgery: Does the anaesthetic make any difference? Brit. J. Anaesth., 78, 347-348.

Coderre, T. J., Katz, J., Vaccarino, A. L., Melzack, R. (1993). Contribution of central neuroplasticity to pathological pain: Review of clinical and experimental evidence. Pain, 53, 259-285.

Deborah, B., Grainne, N., George, H. (2004). Endocrine and metabolic response to surgery. Contin. Educ. Anaesth. Crit. Care Pain, 4 (5), 144-147.

Desborough, J. P. (2000). The stress response to trauma and surgery. Brit. J. Anaesth., 85 (1), 109-117.

Desborough, J. P. (1999). Physiological responses to surgery and trauma. In: Foundations of Anaesthesia (pp. 713-720). Hemmings, H. C. Jr, Hopkins, P. M. (eds.). London: Mosby.

Desborough, J. P., Hall, G. M. (1993). Endocrine response to surgery. In: Anaesthesia Review. Vol. 10 (pp. 131-148). Kaufman, L. (Ed.). Edinburgh: Churchill Livingstone.

Dimitrov, S., Lange, T., Born, J. (2010). Selective mobilization of cytotoxic leukocytes by epinephrine. J. Immunol., 184, 503-511.

Edwards, R. (1997). Thyroid and parathyroid disease. Int. Anesthesiol Clin, 35, 63-83.

Elenkov, I. J., Chrousos, G. P. (2002). Stress hormones, proinflammatory and antiinflammatory cytokines, and autoimmunity. Ann. NY Acad. Sci., 966, 290-303.

Elenkov, I. J., Wilder, R. L., Chrousos, G. P., Vizi, E. S. (2000). The sympathetic nerve-an integrative interface between two supersystems: The brain and the immune system. Pharmacol. Rev., 52 (4), 595-638.

Franke, A., Lante, W., Kurig, E., Zöller, L.G., Weinhold, C., Markewitz, A. (2006). Hyporesponsiveness of $\mathrm{T}$ cell subsets after cardiac surgery: A product of altered cell function or merely a result of absolute cell count changes in peripheral blood? Eur. J. Cardiothorac. Surg., 30 (1), 64-71. 
Freitas, M., Tavan, E., Cayuela, C., Diop, L., Sapin, C., Trugnan, G. (2003). Host-pathogens cross-talk. Indigenous bacteria and probiotics also play the game. Biol. Cell, 95, 503-506.

Golubovska, I., Vanags, I. (2008). Anaesthesia and stress response to surgery. Proc. Latv. Acad. Sci., Section B, 62 (5), 141-147.

Gorbach, S. L. (2000). Probiotics and gastrointestinal health. Amer. J. Gastroenterol., 95 (suppl), S2- S4.

Grainne, N. (2005). Hormonal and metabolic responses to trauma. Anaest. Int. Care Med., 6 (9), 313-314.

Grocott, M. P., Mythen, M. G., Gan, T. J. (2005). Perioperative fluid management and clinical outcomes in adults. Anesth. Analg., 100 (4), 1093-1106.

Hall, G. M., Salmon, P. (2002). Physiological and psychological influences on postoperative fatigue. Anesth. Analg., 95, 1446-1450.

Hart, A. L., Lammers, K., Brigidi, P., Vitali, B., Rizzello, F., Gionchetti, P., Campieri, M., Kamm. M. A., Knight, S. C., Stagg, A. J. (2004). Modulation of human dendritic cell phenotype and function by probiotic bacteria. Gut, 53, 1602-1609.

Hollmann, M. W., Durieux, M. E.,(2000). Local anaesthetics and the inflammatory response: A new therapeutic indication? Anasthesiology, 93, 858-875.

Insler, S. R., Sessler, D. I. (2006). Perioperative thermoregulation and temperature monitoring. Anesthesiol. Clin., 24 (4), 823-837.

Ichikawa, H., Kuroiwa, T., Inagaki, A., Shineha, R, Nishihira, T, Satomi, S, Sakata, T. (1999). Probiotics bacteria stimulate gut epithelial cell proliferation in rat. Dig. Dis. Sci., 44 (10), 2119-2123.

Ivanovs, I., Pavars, A., Vetra, J., Saba, M. (2006). Probiotics use in early postoperative period after large bowel resection. Colorect. Dis. 8 (4) (suppl.), 29.

Jokela, R., Ahonen, J., Valijus, M., Seppälä, T., Korttila, K. (2007). Premedication with controlled-release oxycodone does not improve management of postoperative pain after day-case gynaecological laparoscopic surgery. Brit. J. Anaesth., 98 (2), 255-260.

Karabiyik, L., Sardas, S. (2001). Comparison of genotoxicity of sevoflurane and isoflurane in human lymphocytes studied in vivo using comet assay. Mutat. Res., 492, 99-107.

Kawasaki, T., Ogata, M., Kawasaki, C., Okamoto, K., T. Sata. (2007). Effects of epidural anaesthesia on surgical stress-induced immunosuppression during upper abdominal surgery. Brit. J. Anaesth., 98 (2), 196-203.

Kehlet, H. (1997). Multimodal approach to control postoperative pathophysiology and rehabilitation. Brit. J. Anaesth., 78, 606-617.

Kehlet, H. (1999). Acute pain control and accelerated postoperative surgical recovery. Surg. Clin. N. Amer., 79, 431-443.

Kitching, A. J., O’Neill, S. S. (2009). Fast-track surgery and anaesthesia. Contin. Educ. Anaesth. Crit. Care Pain, 9 (2), 39-43.

Kraehenbuhl, J. P., Corbett, M. (2004). Immunology. Keeping the gut microflora at bay. Science, 303, 1624-1625.

Krüger, K., Mooren, F. C. (2007). T cell homing and exercise. Exerc. Imm. Rev, 13, 37-54

Latterman, R., Carli, F., Wykes, L., Schricker, T. (2003) Perioperative glucose infusion and catabolic response to surgery: The effect of epidural block. Anesth. Analg., 96, 555-562.

Ledowski, T., Bein, B., Hanss, R., Paris, A., Fudickar, W., Scholz, J., Tonner, P. H. (2005). Neuroendocrine stress response and heart rate variability: A comparison of total intravenous versus balanced anesthesia. Anesth. Analg., 101, 1700-1705.

Lin, E., Lowry, F. S., Calvano, E. S. (1999). The systemic response to injury. In: Principles of Surgery. 7th edn. (pp. 3-53). New York: McGraw Hill.

Lyons, F. M., Meeran, K. (1997). The physiology of the endocrine system. Int. Anesthesiol. Clin., 35, 1-21.
Macpherson, A. J., Uhr, T. (2004). Induction of protective IgA by intestinal dendritic cells carrying commensal bacteria. Science, 303, 1662-1665.

Maharaj, C. H., Kallam, S. R., Malik, A., Hassett, P., Grady, D., Laffey, J. G. (2005). Preoperative intravenous fluid therapy decreases postoperative nausea and pain in high risk patients. Anesth. Analg., 100 (3), 675-682.

Manorama, S. (2003). Stress response and anaesthesia altering the peri and post-operative management. Inidan J. Anaesth., 47 (6), 427-434.

Marc, G. H., Timmerman, H. M., et al. (2005). Prevention of infectious complications in surgical patients: Potential role of probiotics. Digest. Surg., 22, 234-244.

Matsuoka, H., Kurosawa, S., Horinouchi, T. (2001). Inhalation anaesthetics induce apoptosis in normal peripheral lymphocytes in vitro. Anaesthesiology, 95, 1467-1472.

Menigaux, C., Fletcher, D., Dupont, X., Guingard, B., Guirimand, F., Chauvin, M. (2000). The benefits of intraoperative small-dose ketmine on postoperative pain after anterior cruciate ligamentrepair. Anaesth. Analg., 90, 129-135.

Miller, G. E., Chen, E., Zhou, E. S. (2007). If it goes up, must it come down? Chronic stress and the hypothalamic-pituitary-adrenocortical axis in humans. Psychol. Bull., 133, 25-45.

Nathan, C. (2006). Neutrophils and immunity: Challenges and opportunities. Nat. Rev. Immunol., 6, 173-182.

Niers, L. E. M., Rijkers, G. T., Timmerman, H. M., Van Bleek, G. M., Van Uden, N. O. P., Kimpen, J. L. L.(2004). A central immunoregulatory role for IL-10 in the suppression of type 2 T-helper cell cytokines by probiotic bacteria. In: Proceedings of the XXIII European Academy of Allergology and Clinical Immunology Congress, Amsterdam. Amsteram.

Ogawa, K., Hirai, M., Katsube, T., Murayama, M., Hamaguchi, K., Shimakawa,T., Nritake, Y., Hosokawa, T., Kajiwara, T. (2000). Suppression of cellular immunity by surgical stress. Surgery, 127(3), 329-336.

Pepys, M. B., Hirschfield, G. M. (2003). C-reactive protein: A critical update. J. Clin. Invest., 111 (12),1805-1812.

Pöpping, D., Elia, N., Marret, E., Remy, C., Tramčr, M. (2008). Protective effects of epidural analgesia on pulmonary complications after abdominal and thoracic surgery: A meta-analysis. Arch. Surg., 143 (10), 990-999.

Puura, A., Puolakka, P., Rorarius, M., Salmelin, R., Lindgren, L. (2006). Etoricoxib pre-medication for post-operative pain after laparoscopic cholecystectomy. Acta Anaesthesiol Scand, 50 (6), 688-693.

Rigg, J. R., Jamrozik, K., Myles, P. S., Silbert, B. S., Peyton, P. J., Parsons, R. W., Collins, K. S. (2002). Epidural anaesthesia and analgesia and outcome of major surgery: A randomised trial. MASTER Anaesthesia Trial Study Group. Lancet, 359, 1276-1282.

Salmon, P., Hall, G. M. (1997). A theory of postoperative fatigue. J. R. Soc. Med., 90, 661-664.

Sanders, V. M., Kavelaars, A. (2007). Adrenergic regulation of immunity. In: Psychoneuroimmunology (4th edn.) (pp. 65-66). Ader, R. (Ed.). Vol. 1. Chapter 2. New York: Elsevier Academic Press.

Scarlett, M., Crawford-Sykes, A., Nelson, M. (2002). Preoperative starvation and pulmonary aspiration. New perspectives and guidelines. West Indian Med. J., 51 (4), 241-245.

Scherer, R. (1997). Intraoperative Wärmekonservierung. Viel Lärm um heiße Luft? [Intraoperative heat conservation. A lot of hot air?]. Anaesthesist, 46 (2), 81-90 (in German).

Segerstrom, S. C., Miller, G. E., (2004). Psychological stress and the human immune system: A meta-analytic study of 30 years of inquiry. Psychol. Bull., 130, 601-630.

Sheeran, P., Hall, G. M., (1997). Cytokines in anaesthesia. Brit. J. Anaesth., 78, 201-219.

Smith, E. M. (2008). Neuropeptides as signal molecules in common with leukocytes and the hypothalamic-pituitary-adrenal axis. Brain Behav. Immun., 22(1), 3-14. 
Sonohata, M., Tsunoda, K., Kugisaki, H., Someya, S., Honke, H.,Mitsunori, Kitajima, M., Mawatari, M., Hotokebuchi, T. (2009). Surgical stress differences between total hiparthroplasty and total knee arthroplasty. Int. J. Med. Sci., 1 (11), 505-509.

Steinbrook, R. A. (1998). Epidural anesthesia and gastrointestinal motility. Anesth. Analg., 86, 837-844.

Stuart, P. C. (2006). The evidence base behind modern fasting guidelines. Best Pract. Res. Clin. Anaesthesiol., 20 (3), 457-469.

Tewes, U. (1999) Concepts in psychology. In: Psychoneuroimmunology. An Interdisciplinary Introduction. Chapter 4 (pp 96-98). New York, NY: Kluwer Academic/Plenum Publishers.

Tilbrook, A.J., Turner, A.I., Clarke, I.J. (2000). Stress and reproduction: Central mechanisms and sex differences in non-rodent species. Stress, $\mathbf{5}$ (2), 83-100.

Timmerman, H. M., Koning, C. J. M., Mudler, L., Rombouts, F.M., Beynen, A.C. (2004). Monostrain, multistrain and multispecies probiotics. A comparison of functionality and efficacy. Int. J. Food Microbiol., 96, 219-233.
Veenhof, A. A., Vlug, M. S., van der Pas, M. H., Sietses, C., van der Peet, D. L., de Lange-de Klerk, E. S., Bonjer, H. J., Bemelman, W. A., Cuesta, M. A. (2012). Surgical stress response and postoperative immune function after laparoscopy or open surgery with fast track or standard perioperative care: A randomized trial. Ann. Surg., 255 (2), 216-221.

Velickovic, I., Yan, J., Gross A. J. (2002). Modifying the neuroendocrine stress response. Semin. Anaesth. Periop. Med. Pain, 21 (1), 16-25.

Souba, W. W., Fink, M. P., Jurkovich, G. J., Kaiser, L. P., Pearce, W. H., Pemberton, J. H., Soper, N. J. (2007). ACS Surgery: Principles and Practice. $6^{\text {th }} e d n$. American College of Surgeons. Philadelphia, PA: BC Decker, Inc. 1956 pp.

Witko-Sarsat, V., Rieu, P., Descamps-Latscha, B., Lesavre, P., HalbwachsMecarelli, L. (2000). Neutrophils: Molecules, functions and pathophysiological aspects. Labor. Investig., 80, 617-653.

Wu, C. L., Naqibuddin, M., Rowlingson, A. J., Lietman, S. A., Jermyn, R. M., Fleisher, L. A. (2003). The effect of pain on health-related quality of life in the immediate postoperative period. Anesth. Analg., 97, 1078-1108.

Zura, M., Sakic, K., Malenica, B., Vrbanovic, V. (2009). Immune response to surgical stress in spinal anaesthesia. Periodicum Biologorum, 111 (2), 193-196.

Received 29 February 2012

\section{PACIENTA ORGANISMA ATBILDE UZ ĶIRURĢISKO STRESU UN IESPĒJAMIE TĀS KOREKCIJAS VEIDI}

Ir zināmi divi galvenie pēcoperācijas stresa sistēmiskie efekti: neiroendokrīnais un hematoimunoloğiskais efekts. Neiroendokrīnu atbildes reakciju inducē hipotalāma-hipofīzes-adrenālās sistēmas un simpato-adrenālās-medulārās sistēmas neironu aktivizācija. Hematoimunoloğisko atbildi raksturo citokīnu produkcija, akūtas fāzes reakcija, limfocìtu un neitrofīlu leikocītu proliferācija. Visi sistēmiski efekti ir cieši saistīti un cits citu ietekmē. Pārāk izteikta stresa atbildes reakcija var novest pie palielinātas pēcoperācijas morbiditātes un pasliktināt operācijas iznākumu. Kiirurǵisku stresu var ietekmēt preoperatīvi, perioperatīvi un postoperatīvi faktori. Rakstā apkopota literatūra par izmaiṇām organismā, kuras notiek kā atbildes reakcija uz ḳirurğisku stresu un apspriestas iespējamās stratēǵijas, kā samazināt stresa atbildes reakciju un tās ietekmi uz organismu. 


\title{
EXPRESSION OF GA COAT PROTEIN-DERIVED MOSAIC VIRUS-LIKE PARTICLES IN Saccharomyces cerevisiae AND PACKAGING in vivo OF mRNAs INTO PARTICLES
}

\author{
Arnis Strods, Dagnija Ārgule, Indulis Cielēns, Ludmila Jackeviča, and Regīna Renhofa
}

Biomedical Research and Study Centre, Rātsupītes ielā 1, Rīgā, LV-1067, LATVIA;

a.strods@biomed.lu.lv

Communicated by Pauls Pumpēns

\begin{abstract}
Our previous research showed that the best yield of virus-like particles (VLPS) formed by RNA bacteriophage GA coat protein was obtained by expression in yeast Pichia pastoris, while other used expression systems in Saccharomyces cerevisiae gave much lower amounts of capsids. The main reasons to attempt further studies in Saccharomyces cerevisiae were to improve the yield of GA-based VLPs using constructs with optimised nucleotide triplets in coding sequences, and to exploit the possibilities of the two-promoter Gal1/Gal10 system of expression vector pESC-URA for production of the desired mosaic VLPS and for packaging of mRNAs into VLPS in vivo.
\end{abstract}

\section{INTRODUCTION}

Yeast expression systems are successfully used for production of heterologous proteins and for generation of viruslike particles (VLPs) of several sources (Strausberg and Strausberg, 2001; Sasnauskas et al., 2002; TsunetsuguYokota et al., 2002; Chen et al., 2004; Juozapaitis et al., 2005; Mach et al., 2006; Freivalds et al, 2011). Our particular interest is the potential of yeast cells as a host for producing properly folded bacteriophage $\mathrm{MS} 2, \mathrm{Q} \beta$ and GA coat protein-derived VLPs (Legendre and Fastrez, 2005; Freivalds et al., 2006; Freivalds et al., 2008; Rūmnieks et al., 2008; Sun et al., 2011), also with simultaneously packaged mRNAs in vivo (Legendre and Fastrez, 2005; Rūmnieks et al., 2008; Sun et al., 2011). Here we continue our previous investigations (Freivalds et al., 2008; Rūmnieks et al., 2008) in several aspects: 1) to improve the yield of VLPs formed by GA coat protein in Saccharomyces cerevisiae by use of optimised, yeast-characteristic codons, 2 ) to produce nanoparticles with in vivo packaged mRNAs coding „,reporter” protein GFP or interleukin-2, 3) to exploit the two-promoter expression system pESC-URA for production of mosaic particles formed from two proteins GA coat protein and this protein fused with the desired eukaryotic sequence, this time with fragment of HIV Tat sequence and with West Nile Virus E protein DIII chain. Such an approach to form mosaic particles often is the only possibility to involve foreign protein sequences into soluble structures and to utilise them in further investigations.

In our previous papers (Freivalds et al., 2008; Rūmnieks et al., 2008), the GA coat protein (CP) encoding gene was amplified from Escherichia coli expression plasmid pGA-355-24. The CP aminoacid sequence encoded by this plasmid is identical to that published by Tars et al., 1997. The coding sequence for this plasmid was obtained by RT of full-length bacteriophage GA RNA, and therefore, it could be designated as original (Escherichia coli specific). Previously it was shown (Freivalds et al., 2008) that the highest yield of GA CP VLPs was obtained in the case of yeast Pichia pastoris. In Saccharomyces cerevisiae, the yield of GA CP-formed particles was lower - up to two times for AH22/pFX-GA and remarkably low for YPH499/ pESCURA. Both Saccharomyces cerevisiae vectors exist in cells as episomes. Our particular interest was vector pESC-URA from Stratagene, which has two regulated promoters Gal1 and Gal10 that are very powerfully induced by galactose (up to 1000-fold). The Gal1 and Gal10 promoters share a common upstream activating sequence, which transcribe in opposite orientations and can be used to express two products simultaneously and in approximately equivalent amounts. To attempt to improve yield of GA CP-derived particles, we decided to switch from original Escherichia coli preferred codons to optimised ones for yeast. It is considered that optimal codons can aid to achieve faster translation rates and higher accuracy of those processes. Optimal codons in fast-growing microorganisms, like Escherichia coli or Saccharomyces cerevisiae, reflect the composition of their respective genomic tRNA pool. Preferred codon usage in $E$. coli and yeast is quite different (Klump and Maeder, 1991). To convert the E. coli original GA CP sequence into an optimal one for yeast, a built-in Saccharomyces cerevisiae codon table from the Invitrogen software package Vector NTI 10 was used. Additional corrections were made by us to eliminate blocks with more than four identical nucleotides. The resulting GA CP coding sequence used in further work is displayed in Figure 1. 


GA CP
GA CP generated
GA CP optimised
aminoacid sequence (1)
GA CP
GA CP generated
GA CP optimised
aminoacid sequence (16)
GA CP
GA CP generated
GA CP optimised
aminoacid sequence (31)
GA CP
GA CP generated
GA CP optimised
aminoacid sequence (46)

\section{GA CP}

GA CP generated

GA CP optimised

aminoacid sequence (61)

GA CP
GA CP generated
GA CP optimised
aminoacid sequence (76)

\section{GA CP}

GA CP generated

GA CP optimised

aminoacid sequence (91)

GA CP

GA CP generated

GA CP optimised

aminoacid sequence (106)

\section{GA CP}

GA CP generated

GA CP optimised

aminoacid sequence (121)
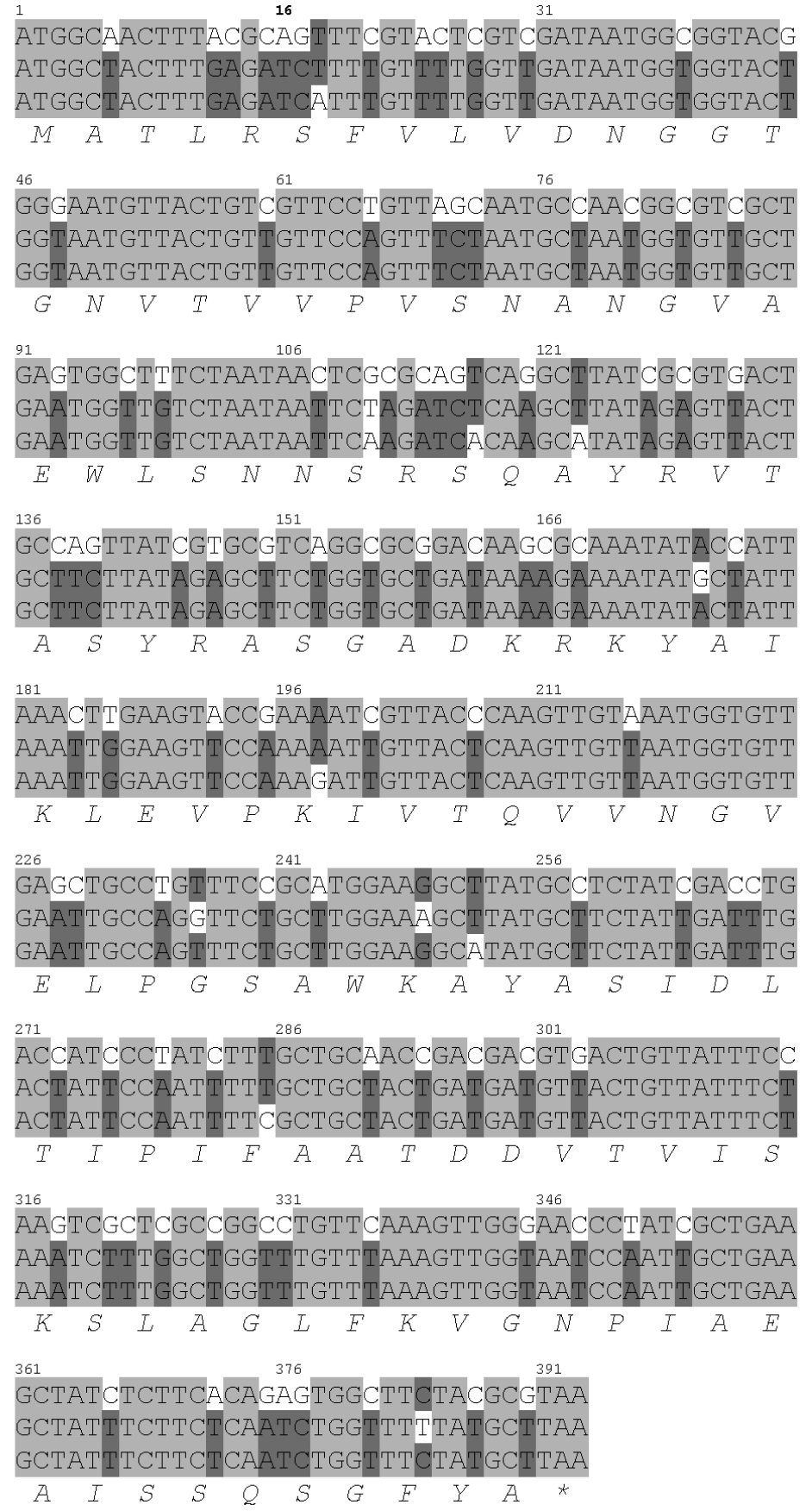

Fig. 1. Comparison of GA CP original, software generated and optimised (manually corrected) codon sequences.

\section{MATERIALS AND METHODS}

Materials. The materials employed were: Anti-Interleukin-2 Antikörper (online-antibodies $\mathrm{GmbH}$ ); Pro-Q ${ }^{\circledR}$ Diamond Phosphoprotein Gel Stain (Molecular Probes, Invitrogen); Shrimp Alkaline Phosphatase (Fermentas); pESC Yeast Epitope Tagging Vectors (Stratagene); plasmid pUC57-GA containing GA coat protein sequence encoded with yeast optimized codons (GeneScript); Yeast Transformation Kit (Sigma) and First Strand cDNA Synthesis Kit (Fermentas).

Plasmids and constructions. All used constructions made by ligation of vectors and appropriate fragments (synthesised in PCR reaction and digested with vector-consistent restriction endonucleases), are summarised in Table 1. Two
S. cerevisiae plasmids with original GA CP gene sequences were already available - pESC-GA was obtained from previous experiments (Freivalds et al., 2008) and pFX-GA was a kind gift from Dr. Andris Kazāks (Freivalds et al., 2008). Constructions with optimised codons were prepared on the basis of those two plasmids:

(1) for expression in yeast AH22, the construction pAS66 was made by cutting the coat protein gene from plasmid pUC57-GA and inserting it in the vector derived from pFX-GA;

(2) for expression in yeast YPH499, constructions pAS65 and pIC971 were synthesised by cloning out the GA CP coding sequence from plasmid pUC57-GA by PCR reaction 
OVERVIEW OF SYNTHESISED PLASMIDS

\begin{tabular}{|c|c|c|c|c|}
\hline \multirow[b]{2}{*}{ Construct } & \multirow[b]{2}{*}{ Input vector } & \multicolumn{3}{|l|}{ Fragment or insert } \\
\hline & & source plasmid & $\begin{array}{l}\text { forward } \\
\text { primer }\end{array}$ & $\begin{array}{l}\text { reverse } \\
\text { primer }\end{array}$ \\
\hline pAS66 & $\begin{array}{l}\text { pFX-GA digested with XbaI } \\
\text { and BglII }\end{array}$ & $\begin{array}{l}\text { pUC57-GA } \\
\text { digested with } \\
\text { XbaI and BglII }\end{array}$ & - & - \\
\hline GAL 10-PYK & 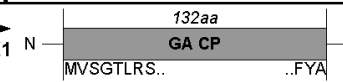 & & & \\
\hline pAS65 & $\begin{array}{l}\text { pESC-GA digested with } \\
\text { BamHI and HindIII }\end{array}$ & pUC57-GA & pARS24 & pARS25 \\
\hline $\overrightarrow{\text { GAL1 }} \mathrm{N}-$ & \begin{tabular}{|c|}
\multicolumn{2}{|c|}{$132 a a$} \\
GA CP \\
\cline { 2 - 2 }
\end{tabular} & & & \\
\hline pIC971 & $\begin{array}{l}\text { pESC-URA digested with } \\
\text { EcoRI and NotI }\end{array}$ & pAS65 & pINC402 & pINC403 \\
\hline \begin{tabular}{|c|c|}
$\mathrm{C}$ & $132 \mathrm{a} a$ \\
\cline { 2 - 2 } & $\mathrm{GACP}$
\end{tabular} & GA CP & & & \\
\hline pIC562 & $\begin{array}{l}\text { pAP409 digested with } \\
\text { Kpn2I and Mph1103I }\end{array}$ & $\begin{array}{l}\text { pTRHis2A- } \\
\text { WNV }\end{array}$ & pWNV-Kpn & pWNV-Mph \\
\hline pDA21 & $\begin{array}{l}\text { pESC-GA digested with } \\
\text { EcoRI and NotI }\end{array}$ & pAK5 & pDAR1 & pARS18 \\
\hline \multicolumn{2}{|c|}{\begin{tabular}{|c|c|c|} 
& $128 a a$ & $14 a a$ \\
$C$ & GA CP & HIV-1 Tat \\
\end{tabular}} & \multicolumn{2}{|c|}{$\vec { A L 1 0 } \longdiv { \text { GAL1 } } \mathrm { N } - \frac { \text { GA CP } } { \text { MVSGTLRS.. } }$} & .FYA $-\mathrm{c}$ \\
\hline pIC929 & $\begin{array}{l}\text { pAS65 digested with EcoRI } \\
\text { and NotI }\end{array}$ & pAS65 & pINC354 & pINC355 \\
\hline pIC930 & $\begin{array}{l}\text { pIC929 digested with Kpn2I } \\
\text { and NotI }\end{array}$ & pIC562 & pWNV-Kpn & pINC356 \\
\hline \multirow{2}{*}{\multicolumn{2}{|c|}{\begin{tabular}{l|r|} 
& $111 \mathrm{aa}$ \\
\cline { 2 - 2 } & WNV DIII \\
\cline { 2 - 3 }
\end{tabular}}} & \multirow{2}{*}{$\underset{\text { GAL10 }}{\overrightarrow{\text { GAL1 }}} \mathrm{N}$} & $\begin{aligned} 132 a a \\
G A C F\end{aligned}$ & \\
\hline & & & MVSGTLRS.. &..$F Y A$ \\
\hline pIC958 & $\begin{array}{l}\text { pAS65 digested with EcoRI } \\
\text { and NotI }\end{array}$ & pAC262 & pINC324 & pINC325 \\
\hline & $\operatorname{L}_{\mathrm{GAL} 10} \mathrm{~N}$ & $\overrightarrow{A L 1} \mathrm{~N}-\frac{}{\text { MVSGTLRS }}$ & $\begin{array}{r}132 a \mathrm{a} \\
\mathrm{GA} \mathrm{CP} \\
\end{array}$ & $-c$ \\
\hline pIC972 & $\begin{array}{l}\text { pIC971 digested with } \\
\text { BamHI and HindIII }\end{array}$ & pAC262 & pINC413 & pINC414 \\
\hline $\mathrm{c}-\overline{\mathrm{AYF}}$ & 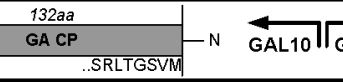 & $\vec{L} 1$ & $\frac{m R N A}{I L-2}$ & $-c$ \\
\hline pIC984 & $\begin{array}{l}\text { pAS65 digested with EcoRI } \\
\text { and NotI }\end{array}$ & $\begin{array}{l}\text { pCEP4-CXCR4- } \\
\text { eGFP }\end{array}$ & pJAR 18 & pJAR19 \\
\hline & $f^{N} \stackrel{\leftarrow \text { GAL10 }}{\leftarrow}$ & $\overrightarrow{A L 1} \mathrm{~N}-\longdiv { \overline { M V S G T L R S } }$ & $\begin{array}{r}132 a a \\
\mathrm{GACP} \\
\end{array}$ & $-c$ \\
\hline pIC921 & $\begin{array}{l}\text { pIC971 digested with } \\
\text { BamHI and HindIII }\end{array}$ & $\begin{array}{l}\text { pCEP4-CXCR4- } \\
\text { eGFP }\end{array}$ & pINC434 & pINC435 \\
\hline AYF.. & 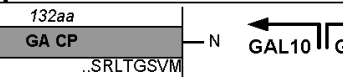 & $\overrightarrow{L 1}$ & $\frac{\text { mRNA }}{\text { EGFP }}$ & $-\mathrm{c}$ \\
\hline
\end{tabular}

and inserting it in plasmid pESC-URA; other plasmids were derived from those two plasmids.

Plasmid pIC562 was constructed to "stick" the West-Nile virus envelope protein domain III (WNV-EDIII) sequence to the C-terminus of Acinetobacter phage AP205 coat protein. The WNV-DIII sequence was cloned from pTRHis2A-WNV plasmid (Martina et al., 2008), inserted in vector plasmid pAP409 (Tissot et al., 2010) and expressed in E. coli JM109 cells.

In the first step, to obtain mosaic virus-like particles, the construction pIC929 was created in which GA CP sequences were inserted under control of both promoters (Gal1 and Gal10). GA CP under control of Gal10 promoter was C-terminally fused with the WNV-EDIII sequence, which was cloned out from construction pIC562. In the case of construction pDA21, pESC-GA plasmid (Freivalds et al., 2008) was modified by inserting, under control of the Gal10 promoter, the GA CP gene that was previously N-terminally prolonged with the HIV-Tat (48-60) sequence (from construction pAK5 for expression in E. coli system). Therefore, this construct was made with $E$. coli-specific codons.

For in vivo packaging, four constructions were made - two with the interleukin 2 (IL2) sequence cloned from plasmid pAC262 (Avots et al., 1990) and two with the eGFP sequence cloned from plasmid pCEP4-CXCR4-eGFP (Strods et al., 2010). Each of the genes was cloned in GA CP containing pESC-URA plasmid, under control of either under Gal1 or Gal10 promoter.

Transformation and protein production. S. cerevisiae strain AH22 competent yeast cells were transformed with 
appropriate plasmids (pFX or pAS66) and cultivated for GA CP expression as described by Freivalds et al., 2008.

S. cerevisiae strain YPH499 competent cells were transformed with appropriate pESC-URA plasmids by using standard lithium acetate/polyethylene glycol procedure (by using Yeast Transformation Kit (Sigma)) as described by Gietz et al. (1992). Transformants were selected on uracilfree agarised synthetic dextrose minimal medium (SDU') according to the manufacturer's protocol. Analytic expression was performed for clone selection. For cell multiplication, $5 \mathrm{~mL} \mathrm{SDU}$ medium and incubation in $30{ }^{\circ} \mathrm{C}$ for $24 \mathrm{~h}$ were used. For expression, $1 \mathrm{~mL}$ inoculum and $5 \mathrm{~mL}$ uracil-free synthetic galactose minimal medium ( $\mathrm{SGU}^{-}$) and incubation in $30{ }^{\circ} \mathrm{C}, 200 \mathrm{rpm}$ for 24 hours were used. Protein content in cells was determined with Western blotting. Selected clones were cultivated for preparative protein expression. $5 \mathrm{~mL}$ of inoculum were incubated in $100 \mathrm{~mL} \mathrm{SDU}^{-}$in $30{ }^{\circ} \mathrm{C}, 200 \mathrm{rpm}$ for 24 hours; the cells were collected by centrifugation (3000 rpm, $5 \mathrm{~min}$ ) and resuspended in 200 $\mathrm{mL} \mathrm{SGU}{ }^{-}$and cultivated for $48 \mathrm{~h}$. Preparative cultivation was conducted in $1 \mathrm{~L}$ flasks.

Purification of VLPs. For purification, 3-8 grams of yeast cells were resuspended in $10 \mathrm{~mL}$ of buffer solution $\mathrm{B}(20$ $\mathrm{mM}$ Tris- $\mathrm{HCl}, 5 \mathrm{mM}$ EDTA, $0.65 \mathrm{M} \mathrm{NaCl}, \mathrm{pH} 7.8$ ) supplemented with $0.03 \mathrm{mM}$ PMSF. For cell disruption, suspension was subjected to the French press (three strokes, 20000 psi), then stirred with $5 \mathrm{~mL}$ glass beads (Sigma) (30 sec of stirring and $1 \mathrm{~min}$ of cooling on ice, 15 cycles) and, finally, sonicated with $22 \mathrm{kHz}$ ultrasound (15 sec of sonication and $1 \mathrm{~min}$ of cooling on ice, 5 cycles). Insoluble cell debris was avoided by centrifugation (30 min, 12000 $\mathrm{rpm}$ ). The pellet wash (with $5 \mathrm{ml}$ of buffer solution B) was added to the previous supernatant for concentration by dialysis against buffer solution B : glycerol (1:1) for 24 hours. Concentrated material was loaded onto a Sepharose CL-4B gelfiltration column $(2 \times 63 \mathrm{~cm})$ with buffer solution B flow rate approximately $2 \mathrm{~mL} \cdot \mathrm{h}^{-1}$.

Capsids were pooled and concentrated by addition of solid ammonium sulphate to $60 \%$ of saturation and incubation overnight at $-18{ }^{\circ} \mathrm{C}$. After centrifugation (15 min, 10000 $\mathrm{rpm})$, the sediment was solubilised into $1 \mathrm{~mL}$ buffer $\mathrm{B}$ and dialysed against buffer TEN (20 mM Tris- $\mathrm{HCl}, 5 \mathrm{mM}$ EDTA, 0.15 M NaCl, pH7.8) with a lower amount of sodium chloride. Contaminant nucleic acids were removed by passing through a short DEAE-Sephadex A50 ion-exchange column according to Rūmnieks et al., 2008.

Final purification of VLPs was performed by sucrose density gradient ultracentrifugation on an ultracentrifuge Optima L-100XP with SW32Ti rotor at 20500 rpm 13 hours. Centrifuge tubes were filled with layers of descending concentrations of sucrose solutions, starting with $36 \%$ on bottom till $5 \%$ on top. After fractionation and analysis, capsids were collected and dialysed against buffer solution B : glycerol $(1: 1)$ and stored.
Analysis of incapsided nucleic acids. Nucleic acids from $0.2 \mathrm{mg}$ of purified capsids were extracted using phenol as described by Rūmnieks et al., 2008. Synthesis of the first strand cDNA was conducted using the First strand cDNA synthesis kit (Fermentas) according to the manufacturer's protocol; 1/10 of extracted RNA was used as a template for each of the corresponding primers - random hexamers, oligo $(\mathrm{dT})_{18}$, forward primer against GA $\mathrm{CP}$, and forward primer against IL-2 or against eGFP gene sequence. For second strand cDNA synthesis by PCR reaction, both forward and reverse primers were added to $2 \mu \mathrm{L}$ of each mixture and products were analysed in agarose gel electrophoresis (Fig. 5).

Polyclonal antibodies against West-Nile virus E protein DIII sequence. Plasmid pIC562 was expressed in E. coli JM109. After ultrasonification of cells in lysis buffer (10 mM Tris-HCl, 5 mM EDTA, 0.03 mM PMSF, pH7.8), soluble proteins were removed by centrifugation at $12000 \mathrm{rpm}$ for 45 min. Fusion protein P562 (AP205 CP - WNV EDIII fragment) was extracted from the pellet with $7 \mathrm{M}$ urea in water and placed on a column with DEAE-cellulose, pre-equilibrated with $0.02 \mathrm{M}$ Tris-HCl, pH8.6. Protein P562 did not absorb and was collected by washing out with equilibration buffer and sedimented with equal volume of saturated ammonium sulphate. For immunisation, a solution of P562 in 7 M urea was prepared.

The immunisation of five Balb/c mice was conducted by simultaneous peritoneal and subcutaneous injections of $25 \mu \mathrm{g}$ of purified virus-like particles in total volume $200 \mathrm{~m} \mu \mathrm{L}$, supplemented with complete Freund's adjuvant (Sigma) in equal amounts. Two re-immunisations were conducted after 14 and 28 days in the same manner, but by using incomplete Freund's adjuvant (Sigma) instead of complete Freund's adjuvant. Mice were bled after 42 days and the collected blood was incubated for $30 \mathrm{~min}$ at $+37^{\circ} \mathrm{C}$ and for $20 \mathrm{~min}$ at $+4{ }^{\circ} \mathrm{C}$. After centrifugation serum was collected and mixed with glycerol $(1: 1)$ for storage in $-20{ }^{\circ} \mathrm{C}$.

Permission from the Food and Veterinary Service was obtained.

Polyacrylamide gel elecrophoresis and Western blotting. PAGE was performed in Tris-glycine buffer with $21 \%$ resolution gel and $6 \%$ stacking gel, and bands were silver-stained according to standard procedure. Western-blots were made with rabbit polyclonal anti - GA CP VLPs (as an antigen for antibody production, GA CP VLPs produced in E. coli (from construction pGA-355-24) and protein A HR peroxidase conjugate (Sigma)) were used.

\section{RESULTS}

A set of plasmids was created to construct GA CP-based mosaic particles and to develop in vivo packaging of VLPs with the desired mRNAs (Table 1). The advantage of the used commercial expression system pESC-URA is it universality, which allows to manufacture plasmids in $E$. coli 
OLIGONUCLEOTIDE PRIMERS USED FOR THE CONSTRUCTION OF PLASMIDS AND RT-PCR

\begin{tabular}{ll}
\hline Oligonucleotide & Nucleotide sequence (5' to 3') \\
pARS24 & TTGGATCCACAATGGCTACTTTGAGATCATTTGTTTTGGT \\
pARS25 & TTTAAGCTTAAGCATAGAAACCAGATTGAGAAGAAATA \\
pINC402 & CCGAATTCACAATGGCTACTTTGAGATCA \\
pINC403 & TAGCGGCCGCTTAAGCATAGAAACCAGATTGAGA \\
pDAR1 & ATGAATTCGGATCCCCATGGGATATGGTCGTAAGAAAC \\
pARS18 & TAGCGGCCGCAAGCTTACGCGTAGAAGCCACTCTGT \\
pINC354 & TCGAATTCATGGCCCCTACTTCAAGTTCTAC \\
pINC355 & ATGCGGCCGCTTAAGTCAGTGTTGAGATGATGC \\
pWNV-Kpn & CATCCGGACAGTTGAAGGGAACAAC \\
pWNV-Mph & GTATGCATTATTTGCCAATGCTGCTTCC \\
pINC356 & ATGCGGCCGCTTATTTGCCAATGCTGCTTCC \\
pINC324 & TCGAATTCATGGCCCCTACTTCAAGTTCTAC \\
pINC325 & ATGCGGCCGCTTAAGTCAGTGTTGAGATGATGC \\
pINC413 & TAGGATCCACAATGGCCCCTACTTCAAGTTCTAC \\
pINC414 & TACAAGCTTAAGTCAGTGTTGAGATGATGC \\
pINC434 & TAGGATCCATGGTGAGCAAGGGCGAGGA \\
pINC435 & TCTAAGCTTACTTGTACAGCTCGTCCATGCC \\
pJAR18 & TCGAATTCCATGGTGAGCAAGGGCGAGGA \\
pJAR19 & GAGCGGCCGCAAGCTTACTTGTACAGCTCGTCCAT \\
p1.561 & TGCCATGGCAACTTTACGCAGTTTCG \\
p1.562 & TGAAGCTTACGCGTAGAAGCCACTCTG \\
&
\end{tabular}

Restriction endonuclease sites are underlined; initiation and termination codons are in bold

as a host and therefore to involve vectors for expression of VLPs in bacteria. Table 2 represents sequences of oligonucleotide primers used to create constructs for VLP production. To check the effect of codon changes made in the $\mathrm{CP}$ coding part of the plasmid on the production of GA CP VLP, we compared yields of capsids with previously exploited construction $\mathrm{pFX}-\mathrm{GA}$ and the new construct pAS66 (Table 1).

Previous work had shown that, comparing the used $S$. cerevisiae systems AH22/pFX-GA and YPH499/pESC-URA, the first of them, which was formaldehyde inducible, gave slightly higher yield of particles (Freivalds et al., 2008). Hence just this system was chosen to compare yield of the product coded by the original $E$. coli-specific sequence and our ,improved” plasmid pAS66. Using pAS66 we obtained stably higher yield of particles, the process became more repeatable, and production reached two milligrams per one gram of yeast cells. Therefore, in our further constructs for the system of interest YPH499/pESC-URA (uracil auxotrophy), new CP coding sequences were exploited, excepting construct pDA21 with E. coli origin codons (Table 3). We focused on two-promoter system possibilities, rather than on the yield of products, as it is well known that $S$. cerevisiae prefers glucose as a carbon source and its growth rate is much higher in glucose than in galactose-containing media, which is necessary for activation of both promoters in pESC-URA. In all cases investigated till now, yield of purified capsids was at least $1 \mathrm{mg}$ per gram of yeast cells.
Table 3

CHARACTERISTICS OF CONSTRUCTIONS EXPRESSED IN THE SYSTEM Saccharomyces cerevisiae YPH499/PESC-URA FOR PRODUCTION OF VLPS

\begin{tabular}{l|l|l|l}
\hline \multicolumn{1}{c}{ Purpose } & $\begin{array}{c}\text { Construction, } \\
\text { number }\end{array}$ & Promoters & \multicolumn{1}{c}{ Genes } \\
\hline VLPs yields & pAS65 & GAL1 & GA CP \\
\hline & pIC971 & GAL10 & GA CP \\
\hline mosaic particles & pDA21* & GAL1 & GA CP \\
& pIC930 & GAL1 & GIV-Tat(48-60) + GA CP \\
\hline packaging in vivo & pIC958 & GAL1 & GA CP \\
of mRNAs & GAL10 & IL2 \\
\cline { 2 - 5 } & pIC972 & GAL1 & IL2 \\
\cline { 2 - 5 } & GAL10 & GA CP \\
\cline { 2 - 5 } & pIC921 & GAL1 & GA CP \\
& pIC984 & GAL1 & GFP \\
& & GAL10 & GA CP
\end{tabular}

* both GA CP coding sequences are E. coli origin

Protein modifications can occur in yeast - particularly phosphorylation, which can affect up to $30 \%$ of the proteome (Ptacek et al., 2005) and usually affects serine residues (Cobitz et al., 1989). Phosphorylation of GA CP in our cases was not observed, which is surprising, as each 129-aminoacid-long GA CP molecule contains 14 serines. In the cases of VLPs produced from plasmids pAS65, 

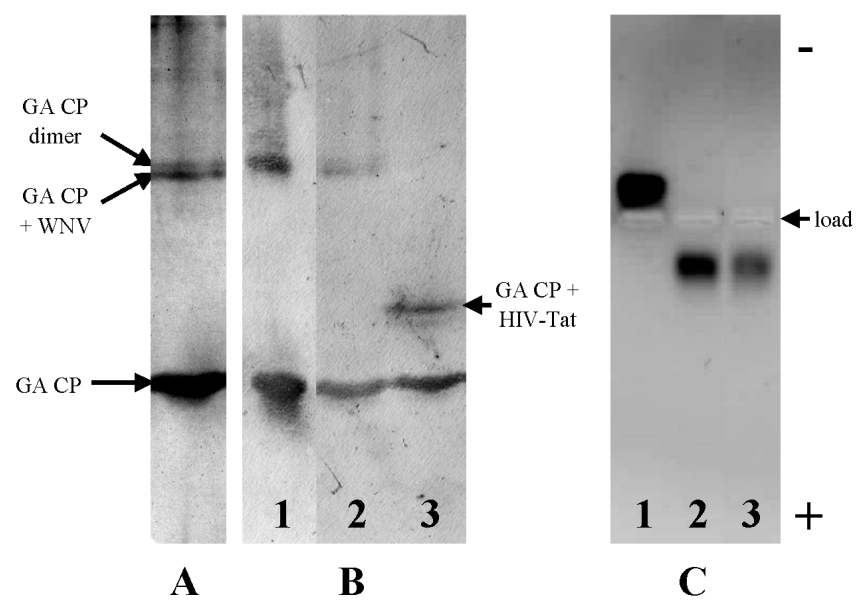

Fig. 2. Analysis of VLPs by PAAG (A and B) and agarose gel (C) electrophoresis: A - silver staining of purified construction IC930 VLPs; B Western blotting of constructions 355-24 (1), IC930 (2) and DA21 (3); C purified VLPs from constructions 355-24 (1), IC930 (2) and IC972 (3).

pAS66, pIC930 and pIC958, two tests (proQ Diamond phosphoprotein gel staining of CP in PAAG and incubation with PME with subsequent electrophoresis of capsids in native agarose gel) did not show phosphorylation of GA (data not shown). It is interesting that electrophoretic mobility of GA CP-formed capsids from E. coli (355-24) and from yeast (pIC930 and pIC972) was quite different in native agarose gels compared with that of coat protein in PAAG (Fig. 2C).

We attempted to obtain mosaic particles consisting of native $\mathrm{CP}$ and of $\mathrm{CP}$ fused with foreign sequences. Two such constructs, pDA21 and pIC930, were successfully expressed (Table 3). In both cases, N- terminal (DA21) and C-terminal (IC930) (Fig. 2A) fusions were involved (Fig. 3A). Two products were obtained: particles with HIV-1 Tat sequence 48-60 (Vivčs et al., 1997) and with West Nile EDIII sequence (Martina et al., 2008) (Fig. 4A). Western-blot analy-
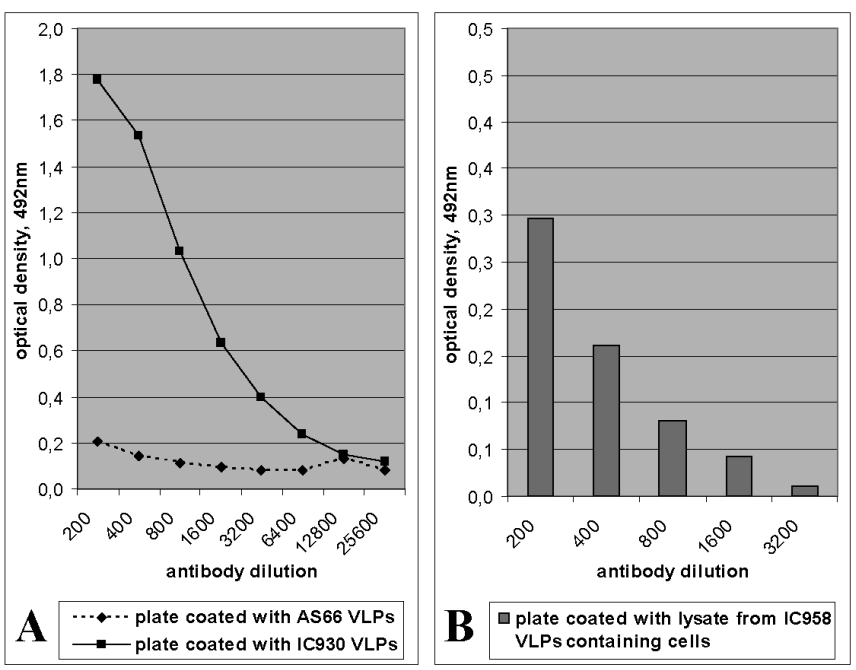

Fig. 3. ELISA immunodetection: A - AS66 and IC930 VLPs with murine polyclonal 562 antibodies against WNV EDIII; B - lysates from cells with expressed construction pIC958 VLPs with anti-interleukin-2 antibodies; displayed values are after subtraction of control (e.g., lysate from untransformed YPH499 cells).
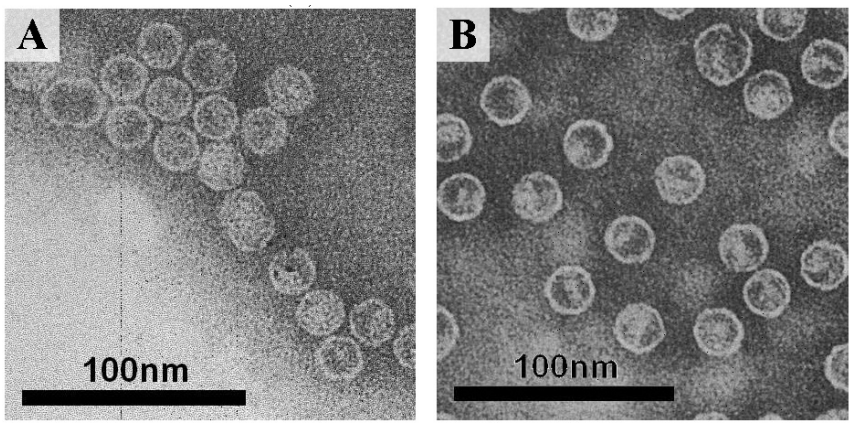

Fig. 4. Electronmicroscopy of mosaic VLPs - construction IC930 (A) and of VLPs with packaged IL-2 mRNA - construction IC972 (B).

sis gave convincing evidence of mosaic particles, as besides monomers and dimers of GA CP, also bands of fused prolonged coat protein (Fig. 2B) were evident. Construct expression in pESC-URA vector allowed to obtain the HIV-1 Tat 48-60 sequence for study as a cell membrane-transducing address. Similar particles obtained by expression in $E$. coli were not formed (data not shown). However, use of another similar construct, in which GA CP was N-terminally fused with the vMIPII fragment (not shown) resulted in capsids in E. coli, but not in yeast. Therefore, the use of both bacterial and yeast expression systems allow us to broaden the set of mosaic virus like particles.

While considering that in the future we need packaged GFP mRNA as a reporter for delivery experiments, two sorts of mRNAs were packaged under control of both promoters that resulted in four constructions: two for packaging of green fluorescent protein (GFP) mRNA (constructions IC984 and IC921) and two for packaging of IL2 mRNA (constructions IC958 un IC972). After accurate purification of produced VLPs, including sucrose density gradient ultracentrifugation to avoid even traces of "stuck" nucleic acids, capsids were treated with phenol and internal nucleic acid was collected. Random hexamer primers indicate the total RNA pool (Fig. 5, lines 1). Primer oligo(dT) allows to visualise all mRNAs, as they have poly(A) tracts (Fig. 5, lines $2)$. The utilised experimental conditions allowed us to compare amounts of mRNA by comparing material in specific PCR product bands. Lines 3 (Fig. 5) showed negligible amounts of GA coat protein mRNA, but cogent bands corresponding to GFP and IL2 coding sequences (Fig. 5, lines $4 \mathrm{a}-4 \mathrm{~d})$ demonstrated packaging of desired mRNAs in vivo into particles.

\section{DISCUSSION}

Yeast provides a source of eukaryotic 5'-capped and 3'-poly(A)-tailed mRNAs, which is attractive considering our goal to use GA VLPs as RNA packaging and delivery tools in mammalian cells. Also, the absence of bacterial endotoxins in yeast preparations is a good reason to choose this system for in vivo packaging studies. In previous studies, genes of interest for packaging were inserted under control of the Gal10 promoter (Legendre and Fastrez, 2005; Rūmnieks et al., 2008). We also used this method, but with 

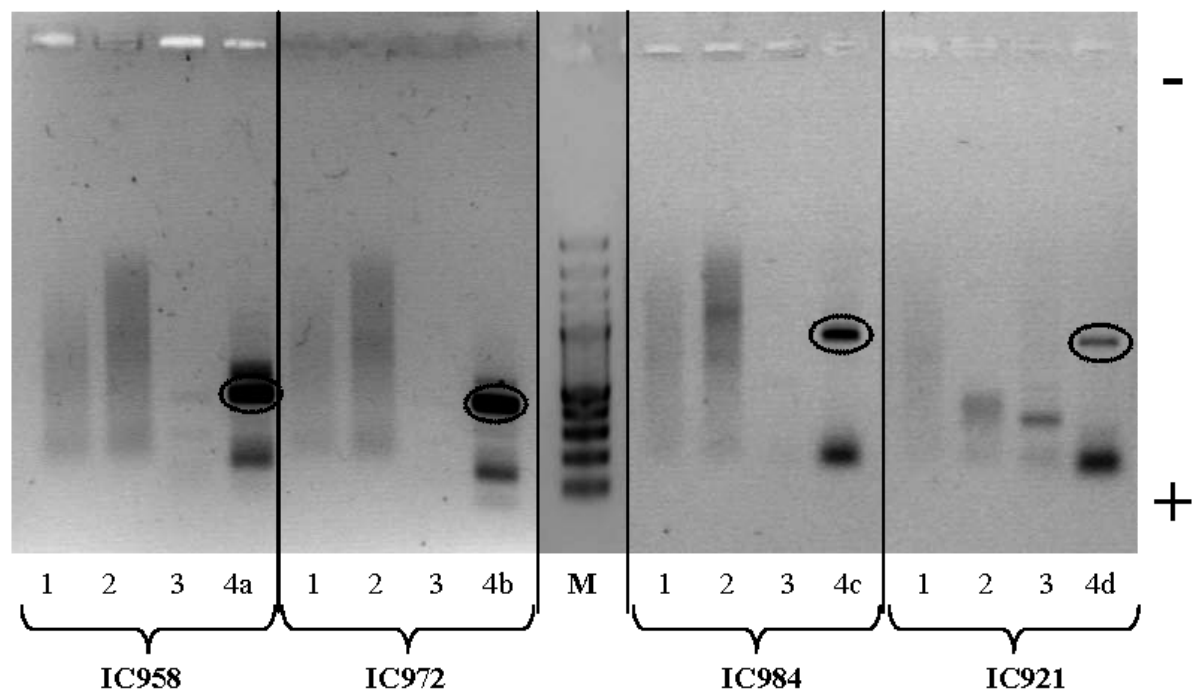

Fig. 5. Analysis of VLPs inner RNA contents by agarose gel electrophoresis. RT-PCR products for constructions IC958, IC972, IC984 and IC921 were compared with a set of different primers: 1 - random hexamer primers; 2 - oligo(dT) 18 primers; 3 - GA CP primers $(\mathrm{p} 1.561+\mathrm{p} 1.562) ; 4 \mathrm{a}-$ construction IC958 with IL2 specific primers pINC324 and pINC325; 4b - construction IC972 with IL2 specific primers pINC413 and pINC414; $4 \mathrm{c}$ - construction IC984 with eGFP specific primers pJAR18 and pJAR19; 4d - construction IC921 with eGFP specific primers pINC434 and pINC435. DNA Ladder 100bp (Fermentas) was used as a marker (M). Ellipses frame bands with densities corresponding to amounts of IL2 mRNA ( $4 \mathrm{a}$ and $4 \mathrm{~b}$ ) and eGFP mRNA (4c and $4 d)$. substituted constructions (Table 1, constructions pIC972 and pIC984). It was previously shown that packaging of heterologous mRNAs into GA CP particles occurred independently of the presence or absence of the specific stem-loop operator sequence (Rūmnieks et al., 2008). This is consistent with the rather low specificity of GA coat protein to structure of the operator (Gott et al., 1991) and explains the encapsidation of different RNAs. Even in the case of MS2 coat protein, which is well known as to form stable replicative complex I (coat protein + operator sequence of RNA), encapsidation efficiency and specificity to a greater extent affects the concentration of mRNA rather than its source (Picket and Peabody, 1993). Therefore, we were interested in examining the yield of GA CP particles and their RNA packaging capacity and specificity by changing promoters for expression of structural coat protein and corresponding mRNA.

Interleukin-2 is a secreted cytokine that is important for Tand B- lymphocyte proliferation. IL2 is produced by T-cells in response to antigenic and mitogenic stimulation and is required for T-cell proliferation and other activities crucial to regulation of the immune response. IL2 can stimulate B-cells, monocytes, lymphokine-activated killer cells and natural killer cells. Despite of unclear, even negative or contradictory results, IL2 still remains a promising therapeutic tool for melanoma and glioma treatment (Fenstermaker and Ciesielski, 2004; Albertini et al., 2008). In VLPs packaged IL2, mRNA is foreseen for local treatment, when VLPs will be able to deliver it into cells. Beside the liposomal intracellular delivery system (Pakunlu et al., 2006), RNA phage MS2 coat protein formed particles were demonstrated as candidates for delivery of mRNAs into eukaryotic cells (Legendre and Fastrez, 2005; Sun et al., 2011). These studies suggest that we are on the path to creating a drug delivery vehicle based on GA coat protein capsids.

\section{ACKNOWLEDGEMENTS}

We wish to thank Prof. Pauls Pumpēns for the idea to use optimised codons for coat protein expression in yeast cells.
We thank also Dr. Velta Ose-Klinklāva for electron microscopy imaging, and Dr. Dace Skrastina for performing mouse immunisation procedures.

We are very grateful to Prof. Kęstutis Sasnauskas and Dr. Aistè Bulavaite from the Institute of Biotechnology, Vilnius University, for the possibility to obtain experience in work with yeasts.

This work was supported by Latvian National Research Programme No. 4 "BIOMEDICINE" project 2010-7/7.2.

\section{REFERENCES}

Albertini, M. R., Hank, J. A., Schalch, H., Kostlevy, J., Cassaday, R., Gan, J., Kim, K., Clements, B., Gillies, S. D., Sondel, P. M. (2008). Phase II trial of hu14.18-IL2 (EMD 273063) for patients with metastatic melanoma. $J$. Clin. Oncol., 26, May 20 Supplement, abstr. 9039.

Chen, H., Lü, J. H., Liang, W. Q., Huang, Y. H., Zhang, W. J.. Zhang, D. B. (2004). Purification of the recombinant hepatitis B virus core antigen ( $\mathrm{rHBcAg}$ ) produced in the yeast Saccharomyces cerevisiae and comparative observation of its particles by transmission electron microscopy (TEM) and atomic force microscopy (AFM). Micron, 35 (5), 311-318.

Cobitz, A. R., Yim, E. H., Brown, W. R., Perou, C. M., Tamanoi, F. (1989). Phosphorylation of RAS1 and RAS2 proteins in Saccharomyces cerevisiae. Proc. Nat. Acad. Sci. USA, 86 (3), 858-862.

Fenstermaker, R. A., Ciesielski, M. J. (2004). Immunotherapeutic strategies for malignant glioma. Cancer Control, 11 (3), 181-191.

Freivalds, J., Dislers, A., Ose, V., Skrastina, D., Cielens, I., Pumpens, P., Sasnauskas, K., Kazaks, A. (2006). Assembly of bacteriophage Qbeta virus-like particles in yeast Saccharomyces cerevisiae and Pichia pastoris. J. Biotechnol., 123 (3), 297-303.

Freivalds, J., Rūmnieks, J., Ose, V., Renhofa, R., Kazāks, A. (2008). Highlevel expression and purification of bacteriophage GA virus-like particles from yeast Saccharomyces cerevisiae and Pichia pastoris. Acta Univ. Latv., 745, Biology, 75-85.

Freivalds, J., Dislers, A., Ose, V., Pumpens, P., Tars, K., Kazaks, A. (2011). High efficient production of phosphorylated hepatitis B core particles in yeast Pichia pastoris. Protein Expr. Purif., 75, 218-224.

Gietz, D., Jean, A. S., Woods, R. A., Schiestl, R. H. (1992). Improved method for high efficiency transformation of intact yeast cells. Nucl. Acids Res., 20 (6), 1425.

Gott, J. M., Wilhelm, L. J., Uhlenbeck, O. C. (1991). RNA binding properties of the coat protein from bacteriophage GA. Nucl. Acids Res., 19 (23), 6499-6503. 
Juozapaitis, M., Slibinskas, R., Staniulis, J., Sakaguchi, T., Sasnauskas, K. (2005). Generation of Sendai virus nucleocapsid-like particles in yeast. $\mathrm{Vi}$ rus Res., 108 (1-2), 221-224.

Klump, H. H., Maeder, D. L. (1991). The thermodynamic basis of the genetic code. Pure Appl. Chem., 63 (10), 1357-1366.

Legendre, D., Fastrez, J. (2005). Production in Saccharomyces cerevisiae of MS2 virus-like particles packaging functional heterologous mRNAs. $J$. Biotechnol., 117 (2), 183-194.

Mach, H., Volkin, D. B., Troutman, R. D., Wang, B., Luo, Z., Jansen, K. U., Shi, L. (2006). Disassembly and reassembly of yeast-derived recombinant human papilloma virus-like particles (HPV VLPs). J. Pharmaceut. Sci., 95 (10), 2195-2206

Martina, B. E., Koraka, P., van den Doel, P., van Amerongen, G., Rimmelzwaan, G. F., Osterhaus, A. D. (2008). Immunization with West Nile virus envelope domain III protects mice against lethal infection with homologous and heterologous virus. Vaccine, 26 (2), 153-157.

Pakunlu, R. I., Wang, Y., Saad, M., Khandare, J. J., Starovoytov, V., Minko, T. (2006). In vitro and in vivo intracellular liposomal delivery of antisense oligonucleotides and anticancer drug. J. Contr. Release, 114 (2), 153-162.

Picket, G. G., Peabody, D. S. (1993). Encapsidation of heterologous RNAs by bacteriophage MS2 coat protein. Nucleic Acids Res., 21 (19), 4621-4626.

Ptacek, J., Devgan, G., Michaud, G., Zhu, H., Zhu, X., Fasolo, J., Guo, H., Jona, G., Breitkreutz, A., Sopko, R., McCartney, R. R., Schmidt, M. C., Rachidi, N., Lee S. J., Mah, A. S., Meng, L., Stark, M. J. R., Stern, D. F., De Virgilio, C., Tyers, M., Andrews, B., Gerstein, M., Schweitzer, B., Predki, P.F., Snyder, M. (2005). Global analysis of protein phosphorylation in yeast. Nature Letters, 438, 679-684.

Rūmnieks, J., Freivalds, J., Cielēns, I., Renhofa, R. (2008). Specificity of packaging mRNAs in bacteriophage GA virus-like particles in yeast Saccharomyces cerevisiae. Acta Univ. Latv., 745, Biology, 145-154.
Strausberg, R. L., Strausberg, S. L. (2001). Overview of protein expression in Saccharomyces cerevisiae. Curr. Protocols Protein Sci. 5.6.1-5.6.7.

Sasnauskas, K., Bulavaite, A., Hale, A., Jin, L., Knowles, W. A., Gedvilaite, A., Dargeviciūte, A., Bartkeviciūte, D., Zvirbliene, A., Staniulis, J., Brown, D. W., Ulrich, R. (2002). Generation of recombinant virus-like particles of human and non-human polyomaviruses in yeast Saccharomyces cerevisiae. Intervirology, 45 (4-6), 308-317.

Strods, A., Petrovska, R., Jackeviča, L., Renhofa R. (2010). Cloning and expression of chemokine receptor CXCR4 in eukaryotic cells CHO, HEK293 and BHK21. Proc. Latv. Acad. Sci. Section B, 64 (3/4), 98-105.

Sun, S., Li, W., Sun, Y., Pan, Y., Li, J. (2011). A new RNA vaccine platform based on MS2 virus-like particles produced in Saccharomyces cerevisiae. Biochem. Biophys. Res. Comm., 407 (1), 124-128.

Tars, T., Bundule, M., Fridborg, K., Liljas, L. (1997). The crystal structure of bacteriophage GA and a comparison of bacteriophages belonging to the major groups of Escherichia coli leviviruses. J. Mol. Biol., 271, 759-773.

Tissot, A. C., Renhofa, R., Schmitz, N., Cielens, I., Meijerink, E., Ose, V., Jennings, G. T., Saudan, P., Pumpens, P., Bachmann, M. F. (2010). Versatile virus-like particle carrier for epitope based vaccines. PLoS One, 5 (3), e9809.

Tsunetsugu-Yokota, Y., Morikawa, Y., Isogai, M., Kawana-Tachikawa, A., Odawara, T., Nakamura, T., Grassi, F., Autran, B., Iwamoto, A. (2003). Yeast-derived human immunodeficiency virus type 1 p55(gag) virus-like particles activate dendritic cells (DCs) and induce perforin expression in Gag-specific CD8(+) T cells by cross-presentation of DCs. J. Virol., 77 (19), 10250-10259.

Vivčs, E., Brodin, P., Lebleu, B. (1997). A truncated HIV-1 Tat protein basic domain rapidly translocates through the plasma membrane and accumulates in the cell nucleus. J. Biol. Chem., 272 (25), 16010-16017.

Авотс А., Бундулис Я., Осе В., Романчикова Н., Скривелис В., Янкевиц Е., Циманис А., Грен Е. (1990). [The expression of the human interleukin-2 gene in Escherichia coli bacteria]. Докл. Акад. Наук CCCP, 315 (4), 994-996 (in Russian).

Received 3 April 2012

\section{GA APVALKA PROTEĪNA ATVASINĀTO MOZAIKĀLO VĪRUSIEM LĪDZĪGO DAḶIṆU EKSPRESIJA Saccharomyces cerevisiae UN mRNS in vivo IEPAKOŠANA DAL̦IṆĀS}

Mūsu iepriekšējie pētījumi parādījuši, ka lielākais RNS bakteriofāga GA apvalka proteīna veidoto vīrusiem līdzīgo daḷiņu (VLD) ieguvums ir ekspresējot tās raugos Pichia pastoris; savukārt, izmantojot Saccharomyces cerevisiae ekspresijas sistēmu, kapsīdu ieguvums ir daudz mazāks. Divi galvenie mērḳi turpmākajām studijām raugos Saccharomyces cerevisiae bija paaugstināt GA apvalka proteīna veidoto VLD ieguvumu, izmantojot konstrukcijas ar optimizētu nukleotīdu tripletu sekvencēm, un izpētìt iespējas, ko varētu sniegt divu promoteru Gal1/Gal10 saturošs ekspresijas vektors pESC-URA vēlamo mozaīkveida VLD iegūšanai un mRNS iepakošanai VLD in vivo. 


\title{
OXIDATIVE STRESS PARAMETERS IN POSTTRAUMATIC STRESS DISORDER RISK GROUP PATIENTS
}

\author{
Vladimirs Voicehovskis*, Gunta Ancāne*, Jūlija Voicehovska**, \\ Grigorijs Orḷikovs**, Jurijs Karpovs**, Igors Ivanovs***, Andrejs Šḳesters****,

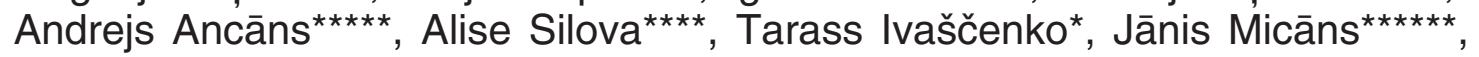 \\ Normunds Vaivads ${ }^{\star \star \star \star \star \star \star}$, and Larisa Umnova** \\ * Department of Psychosomatic Medicine and Psychotherapy, Rīga Stradiṇš University, Kapseḷu iela 23, Rīga, LV-1046, LATVIA; \\ vladimirs.voicehovskis@rsu.Iv \\ ** Internal Diseases Department, Rīga Stradiṇš University, Pilsoṇu iela 13, Rīga, LV-1002, LATVIA \\ *** Rīga 1st Hospital, Bruṇinieku iela 5, Rīga, 1001, LATVIA \\ **** Biochemical Laboratory, Rīga Stradinš University, Dzirciema iela 16, Rīga, LV-1007, LATVIA

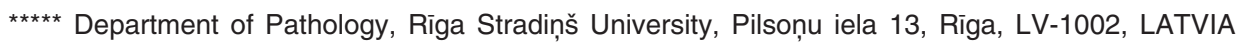 \\ ***** Joint Staff Medical Department, National Armed Forces, LATVIA \\ $\star \star \star \star \star \star \star \star 3 d$ RLC Medical Care Centre, National Armed Forces, LATVIA
}

Communicated by Rafails Rozentāls

Increased excitotoxity in response to stressors leads to oxidative stress (OS) due to accumulation of excess reactive oxygen/nitrogen species. Neuronal membrane phospholipids are especially susceptible to oxidative damage, which alters signal transduction mechanisms. The Contingent of International Operations $(\mathrm{ClO})$ has been subjected to various extreme stressors that could cause Posttraumatic Stress Disorder (PTSD). Former studies suggest that heterogeneity due to gender, race, age, nutritional condition and variable deployment factors and stressors produce challenges in studying these processes. The research aim was to assess OS levels in the PTSD risk group in ClO. In a prospective study, 143 participants who were Latvian CIO, regular personnel, males, Europeans, average age of 27.4, with the same tasks during the mission, were examined two months before and immediately after a six-month Peace Support Mission (PSM) in Afghanistan. $P C L-M$ questionnaire, valid Latvian language "Military" version was used for PTSD evaluation. Glutathione peroxidase (GPX), superoxide dismutase (SOD) and lipid peroxidation intensity and malondialdehyde (MDA) as OS indicators in blood were determined. Data were processed using SPSS 20.0. The MDA baseline was $2.5582 \mu M$, which after PSM increased by $24.36 \%(3.1815$ $\mu M)$. The GPX baseline was $8061.98 \mathrm{U} / \mathrm{L}$, which after PSM decreased by 9.35\% (7308.31 U/L). The SOD baseline was $1449.20 \mathrm{U} / \mathrm{gHB}$, which after PSM increased by $2.89 \%$ (1491.03 U/gHB). The PTSD symptom severity (total PCL-M score) baseline was 22.90 points, which after PSM increased by $14.45 \%$ (26.21 points). The PTSD Prevalence rate (PR) baseline was 0.0357 , which after PSM increased by $147.06 \%$ (0.0882). We conclude that there is positive correlation between increase of OS, PTSD symptoms severity level, and PTSD PR in a group of patients with risk of PTSD - CIO. PTSD PR depends on MDA intensity and OS severity. OS and increased free radical level beyond excitotoxity, is a possible causal factor for clinical manifestation of PTSD.

Key words: Posttraumatic stress disorder, oxidative stress.

\section{INTRODUCTION}

The Contingent of the International Operations appears to be subject to various extreme factor actions, which can cause Posttraumatic Stress Disorder (PTSD). PTSD is an anxiety disorder that can develop after exposure to one or more traumatic events, threatening or causing great physical harm; it is a complex of symptoms experienced by survi- vors of traumatic stress (Satcher, 2000). General PTSD symptoms occur in complex psycho-physiological hypertrophic responses: intrusive experiences of a traumatic event, illusions, hallucinations, persistent avoidance of stimuli associated with trauma, and general emotional numbness, which are present for a period of at least one month. Clinical diagnosis of PTSD, according to the Diagnostic and Statistical Manual of mental disorders (DSM-IV-TR), is per- 
formed by means of a clinical PTSD checklist PCL-M (military version). PCL-M includes 17 items. It is recommended for use as an objective diagnostic tool for examination of patients with PTSD and PTSD risk group patients (Anonymous, 2000; Weathers et al., 2001; Watson et al., 2005; Pynoos et al., 2009; McDonald and Calhoun, 2010).

According to available literature data, the PTSD level before Peace Support Missions has been reported as high as 2.4-9.3\% in the American Contingent of the International Operations (Hoge et al., 2004; Riddle et al., 2007) and $2.4 \%$ in the British Contingent of the International Operations (Iversen et al., 2009). PTSD level after Peace Support Mission is reported as $11.2 \%$ in the American Contingent of the International Operations (Hoge et al., 2004) and 4.0-9.5\% in the British Contingent of the International Operations (Hotopf et al., 2006; Iversen et al., 2009). Pathophysiology and pathogenesis of PTSD is associated with excitotoxity. Excitotoxity is the pathological process by which neurons are damaged due to hyperactivations of the excitatory neurotransmitter glutamate ( $\mathrm{Li}$ et al., 2001, Jourdain et al., 2007). Excitotoxity-activated microglia cells appear to become probable sources of chronic oxidative processes leading to oxidative stress (Anwyl, 1991). Neuronal membrane phospholipids are especially vulnerable to damage; the injury leads to the receptor-mediated signal transduction and, furthermore, information processing disorders. Studies on the effects of hyperoxidation, oxidative and carbonyl stresses on cerebral suppression and its relation to brain degeneration with respect of neuronal functions are of great interest and importance. Indeed there are difficulties in rating and interpreting of available literature data, as the studies are inhomogeneous in gender, race, age, nutritional and deployment factors - reservists or regular personnel, and different stressful military experiences in various Peace Support Missions.

Oxidative stress intensity was assessed considering the malondialdehyde (MDA) plasma level. Unsaturated carbonyl MDA is one of the most frequently used direct indicators of lipid peroxidation. MDA measurement appears to be a suitable quantification method of the end-products of lipid peroxidation. The production of MDA is used as a biomarker to measure the level of OS in an organism and is often used in oxidative stress studies (Moore and Roberts, 1998; Del Rio et al., 2005; Nie et al., 2007). MDA is a naturally occurring metabolic product of polyunsaturated fat degradation (lipid peroxidation), and has been reported to be mutagenic and carcinogenic. Free radical damage to lipids results in MDA reacting with DNA to form adducts to deoxyguanosine and deoxyadenosine and releasing an intermediate product of formaldehyde (Nie et al., 2007). Formaldehyde at low concentrations induces protein misfolding causing a high cytotoxic aggregation. As a metabolic product, MDA might weaken cerebral function during oxidative stress through breaking the homeostasis between excitatory and inhibitory neurons. Being less active than other free radical, MDA has a rather longer half-life and, thereby, can diffuse from the generation places to other sites, bringing further oxidative stress. Cells are equipped with enzymatic and nonenzymatic antioxidant systems to eliminate ROS/RNS and maintain redox homeostasis. A major class of enzymatic antioxidants, which catalyze the dismutation of superoxide into oxygen and hydrogen peroxide, is known as superoxide dismutase (SOD). Multiple isoforms of SOD exist in different cellular compartments. SOD1 (CuZnSOD) is the major superoxide scavenger found in the cytoplasm, mitochondrial intermembrane space, nucleus, and lysosomes, whereas SOD2 (MnSOD) and SOD3 are found in the mitochondria and extracellular matrix, respectively. Indeed, they impart an important antioxidant defence system and their activity increases upon oxidative stress. Some SOD isoforms resulting from oxidative stress have been linked with human diseases. Thus, mutations in the CuZnSOD can result in familial amyotrophic lateral sclerosis (Milani et al., 2011). Further conversion of hydrogen peroxide occurs through the action of catalase, a heme-based enzyme that is normally localised in the peroxisome. Hydrogen peroxide also can be converted to oxygen through coupled reactions with the conversion of reduced glutathione to oxidized glutathione, catalysed by glutathione peroxidase $(\mathrm{GPx})$. The main biological role of GPx is to protect the organism from oxidative damage. The biochemical function of GPx is to reduce lipid hydroperoxides to alcohols as well as to reduce free hydrogen peroxide to water (Miyamoto et al., 2003). GPx scavenges extremely active hydroxyl radicals without formatting toxic adverse products. GPx is present in a high concentration in the cells and plays a crucial role in ensuring them in a reduced state. The GPx role as antioxidant is particularly important for brain, as it is very sensitive to presence of free radicals. Insufficient GPx amount and/or activity can complicate oxidative stress. Five isoforms of selenium (Se)-dependent GPx are found in humans. Furthermore, enzymes such as glutathione S-transferases are known to have Se-independent peroxidase activity. Nonenzymatic antioxidants (thioredoxin, glutaredoxins, peroxiredoxins), recognised to execute thioldisulfide exchange reactions, also play a major role in maintaining cellular redox balance (Trachootham et al., 2008).

Our research aim was to assess oxidative stress levels PTSD and their correlation in the Contingent of the International Operations.

\section{MATERIALS AND METHODS}

The prospective study was conducted in the Department of Psychosomatic Medicine and Psychotherapy, Rīga Stradņš University (Riga, Latvia) in close cooperation with the Biochemical Laboratory (Rīga, Latvia) and Department of Internal Diseases (Rīga, Latvia) of Rīga Stradiņš University, and Medical Care Centre of the National Armed Forces (Rìga, Latvia). The protocol of study, the protocol of agreement, and the protocol of participation corresponded to the Helsinki declaration on principles of humanity in medicine. The study design was approved by the Ethics Committee of Rīga Stradiņš University, protocol No. E-9(2) of 17.12.2009. For our research we used a participant group with the highest possible level of homogeneity to avoid dif- 
ficulties in rating and interpreting of results. In total there were 143 male European participants, average age 27.4, regular military personnel, participants of the Latvian Contingent of the International Operations. Examination was performed before and after the same Peace Support Mission in Afghanistan (six months), with the same tasks during the mission. Clinical examination and laboratory parameters assessment were taken twice: two months before the mission (BL) and immediately after the mission (PL).

Clinical examination was made according to the diagnostic pattern DSM-IV-TR (Anonymous, 2000). The following diagnostic criteria were assessed:

Criterion A: Stressor. The person has been exposed to a traumatic event in which both of the following have been present:

1. The person has experienced, witnessed, or been confronted with an event or events that involve actual or threatened death or serious injury, or a threat to the physical integrity of oneself or others;

2. The person's response involved intense fear, helplessness, or horror.

Criterion B: Intrusive recollection. The traumatic event is persistently re-experienced in at least one of the following ways:

1. Recurrent and intrusive distressing recollections of the event, including images, thoughts, or perceptions;

2. Recurrent distressing dreams of the event;

3. Acting or feeling as if the traumatic event were recurring (includes a sense of reliving the experience, illusions, hallucinations, and dissociative flashback episodes, including those that occur upon awakening or when intoxicated);

4. Intense psychological distress at exposure to internal or external cues that symbolise or resemble an aspect of the traumatic event;

5. Physiologic reactivity upon exposure to internal or external cues that symbolise or resemble an aspect of the traumatic event.

Criterion C: Avoidant/numbing. Persistent avoidance of stimuli associated with the trauma and numbing of general responsiveness (not present before the trauma), as indicated by at least three of the following:

1. Efforts to avoid thoughts, feelings, or conversations associated with the trauma;

2. Efforts to avoid activities, places, or people that arouse recollections of the trauma;

3. Inability to recall an important aspect of the trauma;

4. Markedly diminished interest or participation in significant activities;
5. Feeling of detachment or estrangement from others;

6. Restricted range of affect (e.g., unable to have loving feelings);

7. Sense of foreshortened future (e.g., does not expect to have a career, marriage, children, or a normal life span).

Criterion D: Hyper-arousal. Persistent symptoms of increasing arousal (not present before the trauma), indicated by at least two of the following:

1. Difficulty falling or staying asleep;

2. Irritability or outbursts of anger;

3. Difficulty concentrating;

4. Hyper-vigilance;

\section{Exaggerated startle response;}

Criterion E: Duration. Duration of the disturbance (symptoms in $\mathrm{B}, \mathrm{C}$, and $\mathrm{D}$ ) is more than one month.

Criterion F: Functional significance. The disturbance causes clinically significant distress or impairment in social, occupational, or other important areas of functioning.

PCL checklist was worked out at PTSD National Centre, USA in 1993. The PCL has a variety of purposes, including screening individuals for PTSD, diagnosing PTSD, monitoring symptom change during and after treatment. There are three versions of the PCL: PCL-C (civilian), PCL-M (military) and PCL-S (specific). PCL-M asks about symptoms in response to "stressful military experiences" and is used for active service members and veterans (Weathers et al., 2001; Watson et al., 2005; McDonald and Calhoun, 2010). The PTSD Checklist (PCL) is a 17-item self-report measure of the 17 DSM-IV symptoms of PTSD. Respondents are asked about certain troubles during the last month; the answers are evaluated by a 5-point scale. The valid Latvian language PCL-M version was used for objective PTSD evaluation (Voicehovskis et al., 2011). PTSD risk group Incidence rate (IR) was also assessed.

Laboratory assessment of oxidative stress parameters in blood included: intensity of lipid peroxidation assessed by malondialdehyde (MDA) concentration and activity of antioxidant enzymes: glutathione peroxidase (GPx) and superoxide dismutase (SOD). Blood samples were taken from all individuals in morning at 8.00 (before meal). Venous blood was collected into a vacutainer (Venoject II BD) containing lithium/heparin as an anticoagulant.

Activity of glutathione peroxidase 3 (GPx), Enzyme Commission number (EC) 1.11.1.9, was determined in heparinised whole blood by the method of Paglia and Valentine (Paglia and Valentine, 1967) using commercial tests manufactured by Randox Laboratories (UK, Antrium) in a RX Daytona analyser. GPx catalyses the oxidation of glutathione (GSH) by cumene hydroperoxide. In the presence of glutathione reductase and nicotinamide adenine dinucleo- 
THE MAIN RESULTS BEFORE (BL) AND AFTER (PL) THE PEACE SUPPORT MISSION (PSM) (one-sample Kolmogorov-Smirnov test)

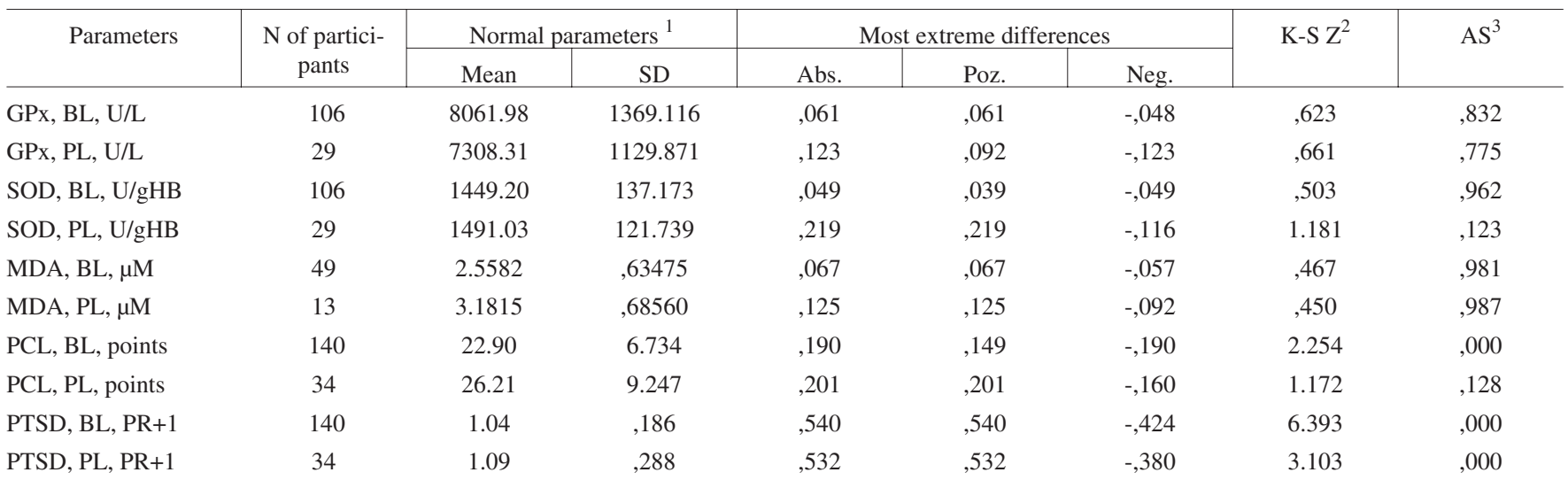

${ }^{1}$ Test distribution is normal; calculated from data; ${ }^{2}$ Kolmogorov-Smirnov Z; ${ }^{3}$ asymptotic significance; SD, standard deviation; GPx, glutathione peroxidase; SOD, superoxide dismutase; MDA, malondialdehyde; PTSD, Posttraumatic Stress Disorder; PCL-M, PTSD Checklist - Military Version

tide phosphate (NADPH) the oxidised glutathione (GSSG) is immediately converted to the reduced form with a concomitant oxidation of NADPH to the oxidised NADP ${ }^{+}$. The decrease in absorbance at $340 \mathrm{~nm}$ is measured. In the presence of hydroperoxide, GPx catalyses oxidation of GSH to GSSG. The latter (GSSG) undergoes NADPH-dependent reduction to GSH catalysed by glutathione reductase. This reaction is accompanied by NADPH oxidation to NADP+. Thus, activity of GPx corresponds to the decrease in absorbance at $340 \mathrm{~nm}$ induced by NADPH oxidation and one unit of enzyme activity is defined as the enzyme content required for oxidation of $1.0 \mu \mathrm{mol}$ of NADPH per $1 \mathrm{~min}$ at $340 \mathrm{~nm}$ and $37^{\circ} \mathrm{C}$.

Malondialdehyde (MDA) level in plasma was measured as suggested by Gavrilov (Гаврилов и др., 1987): at low pH and elevated temperature, MDA readily participates in nucleophilic addition reaction with 2-thiobarbituric acid (TBA), generating a red 1:2 MDA: TBA adduct. The reaction products was extracted with butanol and estimated at $535 \mathrm{~nm}$ and $580 \mathrm{~nm}$ by spectrophotometry.

The determination of superoxide dismutase (SOD, EC 1.15.1.1) employed xantine and xantine oxidase to generate superoxide radicals that react with 2-(4-iodophenyl)-3-(4nitrophenol)-5-phenyltetrazolium chloride to form a red formazan dye (Woolliams et al., 1983). The SOD activity was then measured by the degree of inhibitation of this reaction.

Data were processed using SPSS 20.0. Statistical significance of mean values was evaluated by means of the Paired-Samples T-Test and one-Sample KolmogorovSmirnov test. Interrelationship between parameters was evaluated by the Wilcoxon correlation coefficient; differences were considered as statistically significant at $P<0.05$.

\section{RESULTS}

The main results before PSM (BL) and after (PL) the mission are represented in the Table 1.
T able 2

PTSD MORBIDITY BEFORE (BL) AND AFTER (PL) THE MISSION

\begin{tabular}{l|c|c|c|c|c}
\hline Group & Number, $\mathrm{n}$ & $\begin{array}{c}\text { Average } \\
\text { age, years }\end{array}$ & $\begin{array}{c}\text { Response } \\
\text { rate }\end{array}$ & $\begin{array}{c}\text { Prevalence } \\
\text { rate }\end{array}$ & $\begin{array}{c}\text { Incidence } \\
\text { rate }\end{array}$ \\
\hline BL gr. & 143 & 27.36 & 97.90 & 0.0357 & - \\
PL gr. & 37 & 26.20 & 91.89 & 0.0882 & 0.1765
\end{tabular}

PTSD, Posttraumatic Stress Disorder

Baseline PTSD Prevalence rate (PR) was 0.0357, which after PSM PTSD PR increased by $147.06 \%$ to 0.0882 units (Table 2).

Baseline MDA plasma level (MDA BL, see Fig. 1) was $2.5582 \mu \mathrm{M}$, which after PSM MDA level (MDA PL) increased by $24.36 \%$ till $3.1815 \mu \mathrm{M}$ (Fig.2).

Baseline GPx activity (GPx BL, see Fig. 3) was 8061.98 U/L, which after PSM GPx level (GPx PL) decreased by 9.35\% till 7308.31 U/L (Fig. 4).

Baseline SOD plasma activity (SOD BL, see Fig. 5) was 1449.20 U/gHB, which after PSM SOD (SOD PL) increased by $2.89 \%$ till $31491.03 \mathrm{U} / \mathrm{gHB}$ (Fig. 6).

Baseline PTSD symptom severity (PCL-M score, points, BL, see Fig. 7) total score was 22.90 PCL-M points, after PSM PCL-M score increased by $14.45 \%$ to 26.21 points (Fig. 8).

A negative correlation was found between MDA and GPx (Fig. 9).

\section{DISCUSSION}

Prevalence of oxidation processes accompanied by antioxidant defence system failure leads to the development of oxidative stress, which is one of the universal mechanisms of tissue damage. Enzymatic activity of antioxidant systems (catalase, SOD, glutathione peroxidase) in the brain is sig- 


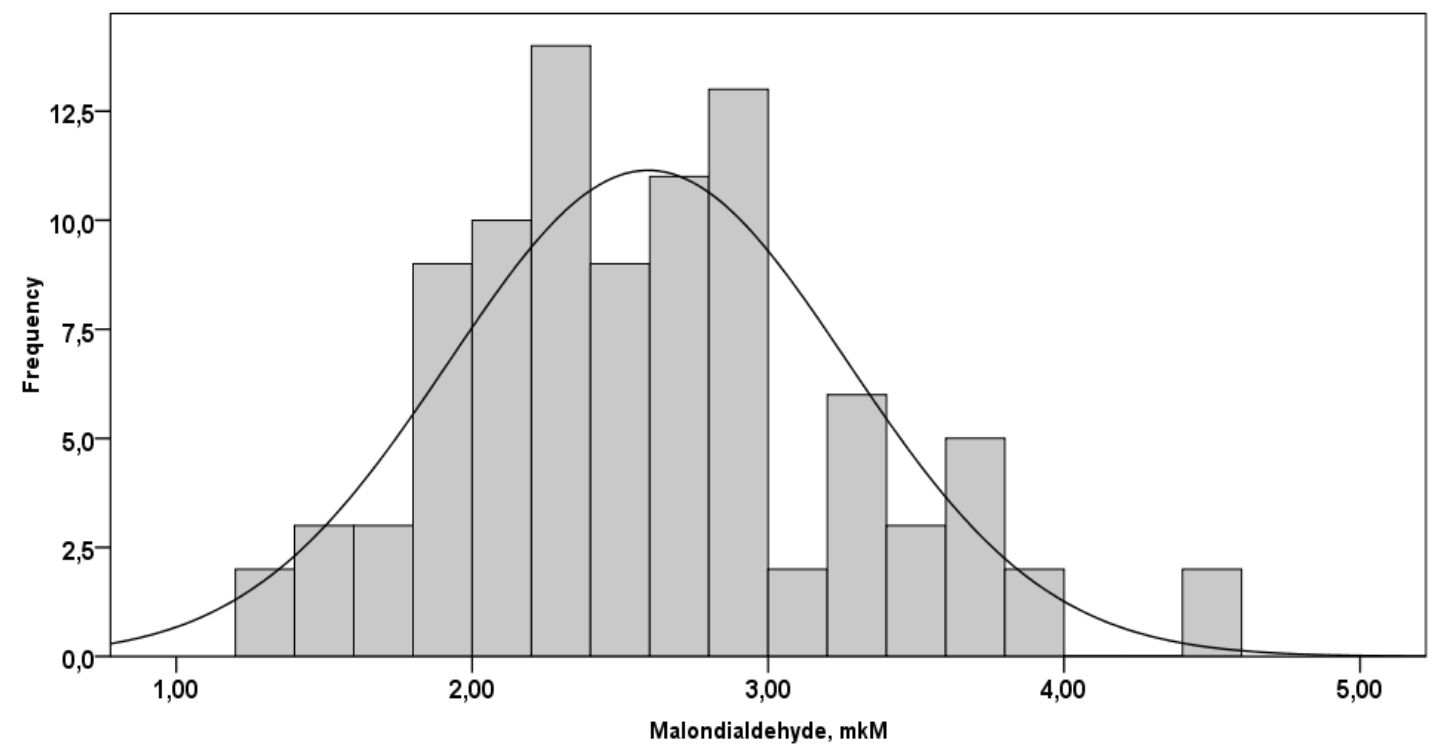

Fig. 1. Malondialdehide level distribution before the mission (BL).

nificantly lower than in other tissues. Oxygen radicals (having oxygen with an unpaired electron) are superoxide anion and hydroxyl radical. These are extremely aggressive. Glutamate is a substrate that is able to support maximal $\mathrm{H}_{2} \mathrm{O}_{2}$ production rates by means of $\left[\mathrm{Ca}^{2+}\right]$ mediated excitotoxity. Scavengers of free radicals are located in the cytoplasm or on cell membranes; these are mainly substances with low molecular weight: superoxide dismutase, glutathione, glutathione peroxidase, catalase, ceruloplasmin, vitamin A, vitamin E, vitamin $\mathrm{C}$, vitamin $\mathrm{K}$, flavonoids, and coumarins. Lipid peroxidation plays a crucial role in brain injury. The brain contains a large amount of lipids $(50 \%$ in a dry matter); most of them appear to be unsaturated and become substrates for lipid peroxidation. Phospholipids account for over half of all lipids of nervous tissue. Fatty acid and phospholipids determine structural and functional features of cell membranes, and contribute to its penetration and density. Lipid peroxidation of any intensity results in functional brain disorder (Esterbauer and Cheeseman, 1990; Ginsberg and Bogousslauvsky, 1998). Moreover, it could become a

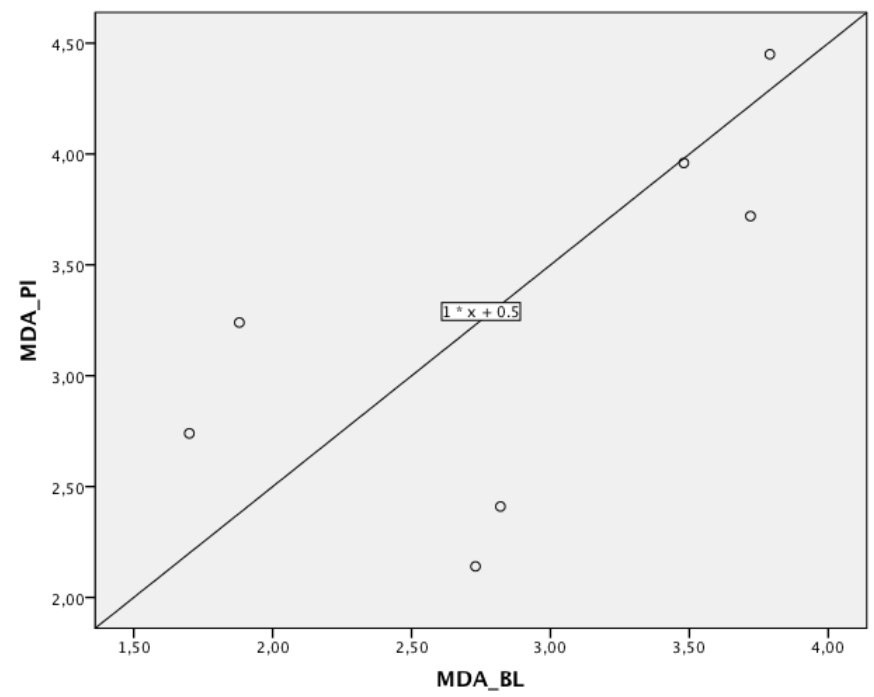

Fig. 2. Relationship of malondialdehide (MDA) before (BL) vs MDA after the mission (PL).

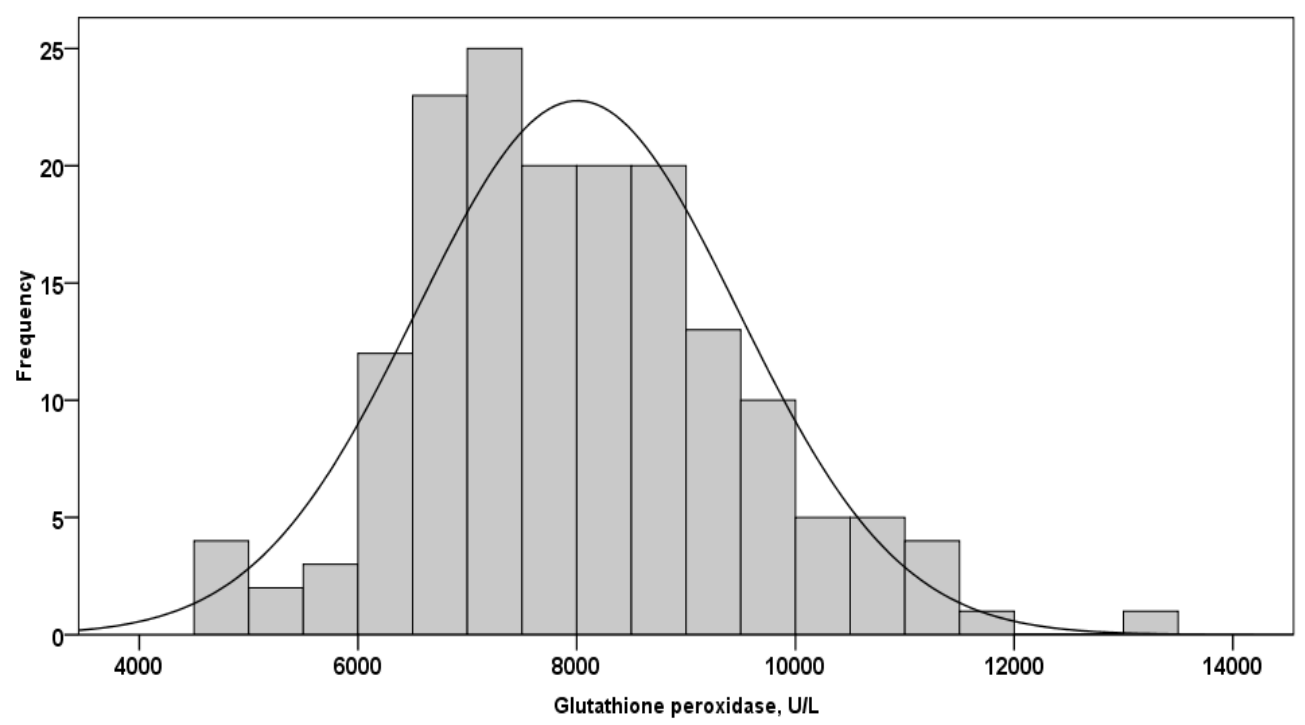

Fig. 3. Glutathione peroxidase level distribution before the mission. 
cause of structural and morphological alterations, and degeneration processes.

The PTSD patients note problems in cognition (memory, attention), somatic concerns (headache), and affective deregulation (impulsivity, irritability, anxiety), particularly in the time period shortly after the traumatic event (whether psychological, biomechanical, or both). A biochemical mechanism associated with elevated levels of oxidative stress parameters has been proposed to explain the etiology of PTSD (common etiology of posttraumatic stress disorder, fibromyalgia, chronic fatigue syndrome and multiple chemical sensitivity) (Pall, 2001; Pall and Satterlee, 2001; Pall, 2007; Adibhatla and Hatcher, 2008). Alterations of glutamatergic and NMDA receptor functions play a role in the etiology of PTSD in humans. Some clinical studies have observed a marked increase of cerebral neurotransmitter glutamate in PTSD (Moghaddam et al., 1994; Chambers et al., 1999; Cortese and Phan, 2005). Stress increases glutamate release,

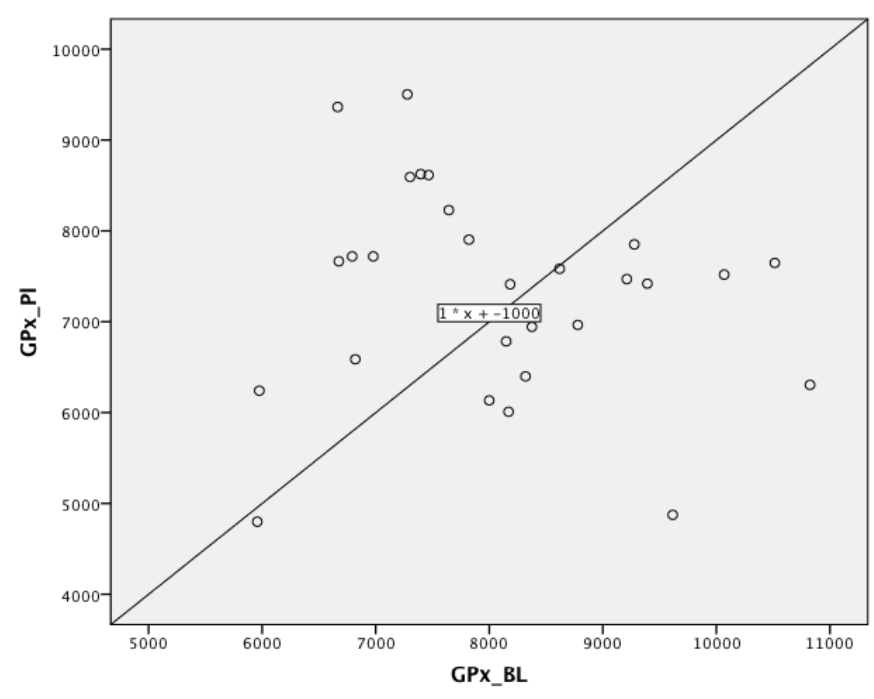

Fig. 4. Glutathione peroxidase before (BL) vs after the mission (PL).

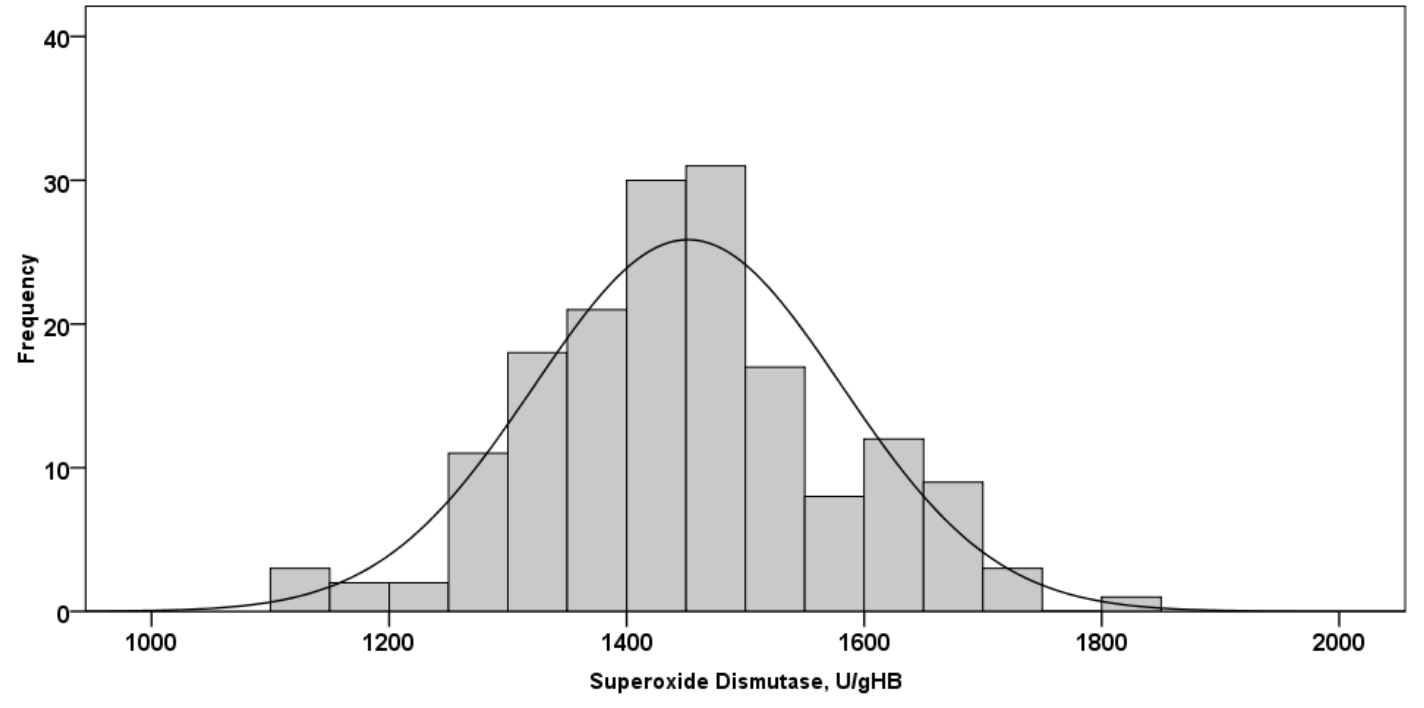

Fig. 5. Superoxide dismutase level distribution before the mission. which is recognised as an important mediator of excitotoxity. Since a prominent role of glutamate-related excitotoxity followed by neuronal damage, glutamatergic pathways may have an important role in stress-related hippocampal degenerative pathology and cognitive deficits seen in patients with PTSD (Moghaddam et al., 1994). Brain imaging studies have revealed a marked reduction in hippocampal volume (Sapolsky, 2000; Reul and Nutt, 2008). Such morphological alterations appear to be positively correlated with the degree of cognitive deficit noted in these patients. PTSD-induced oxidative stress has been proposed to occur in this disorder. Recent clinical studies confirmed the involvement of neurodegenerative pathology in the PTSD pathogenesis (Bremner, 2002). Neurochemically-mediated damage could be conceivably related to neurohumoral dysregulation.

The main conclusions are:

1. MDA intensity increased during PSM; MDA intensity reflects the rate of lipid peroxidation and OS severity.



Fig. 6. Superoxide dismutase (SOD) before (BL) vs after the mission (PL). 


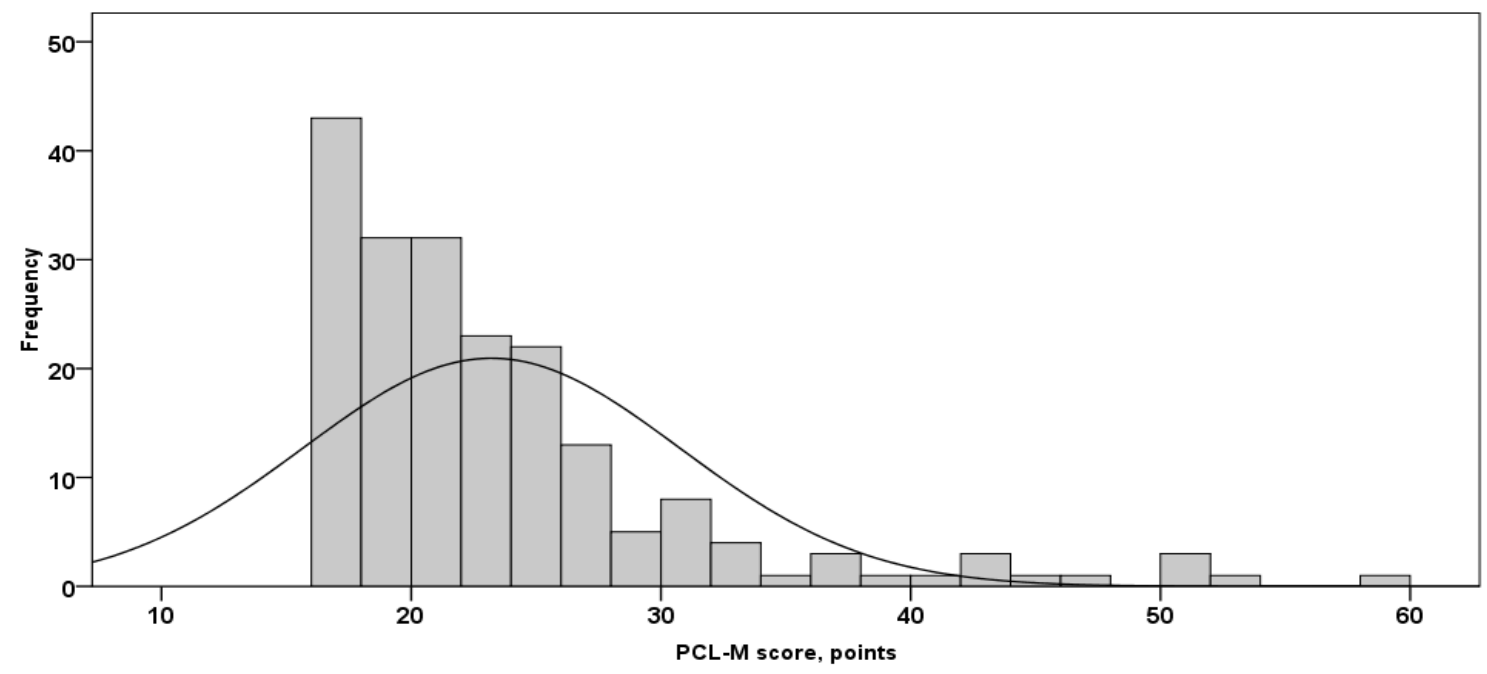

Fig. 7. PCL-M scores distribution, points, before the mission.

PCL-M, Posttraumatic Stress Disorder Checklist - Military Version

2. GPX activity is decreased in the PTSD risk group and is not efficient to overwork and/or control OS.

3. SOD activity is increased in the PTSD risk group but is not efficient to overwork and/or control OS.

4. There is positive correlation between increase of oxidative stress - MDA level, PTSD symptom severity level, and PTSD Prevalence rate (PR) in the studied group of patients with risk of PTSD (Contingent of the International Operations). PTSD PR depends on MDA intensity and OS severity.

Our results suggest that the production of free radicals resulteing in lipid peroxidation seemed to be related to PTSD. The present results showed that patients with PTSD differed from healthy controls in both antioxidant system activity (GPx, SOD) and lipid peroxidation (MDA) level. Therefore, we conclude that OS, increased free radical level beyond excitotoxity, is a possible causal factor for clinical manifes-

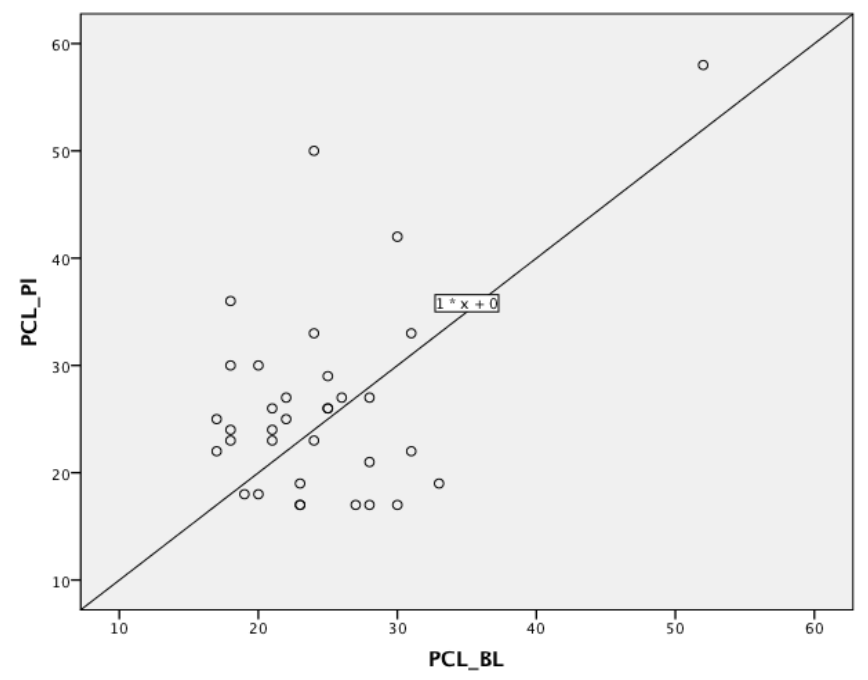

Fig. 8. PCL-M score before (BL) vs after the mission (PL).

PCL-M, Posttraumatic Stress Disorder Checklist - Military Version

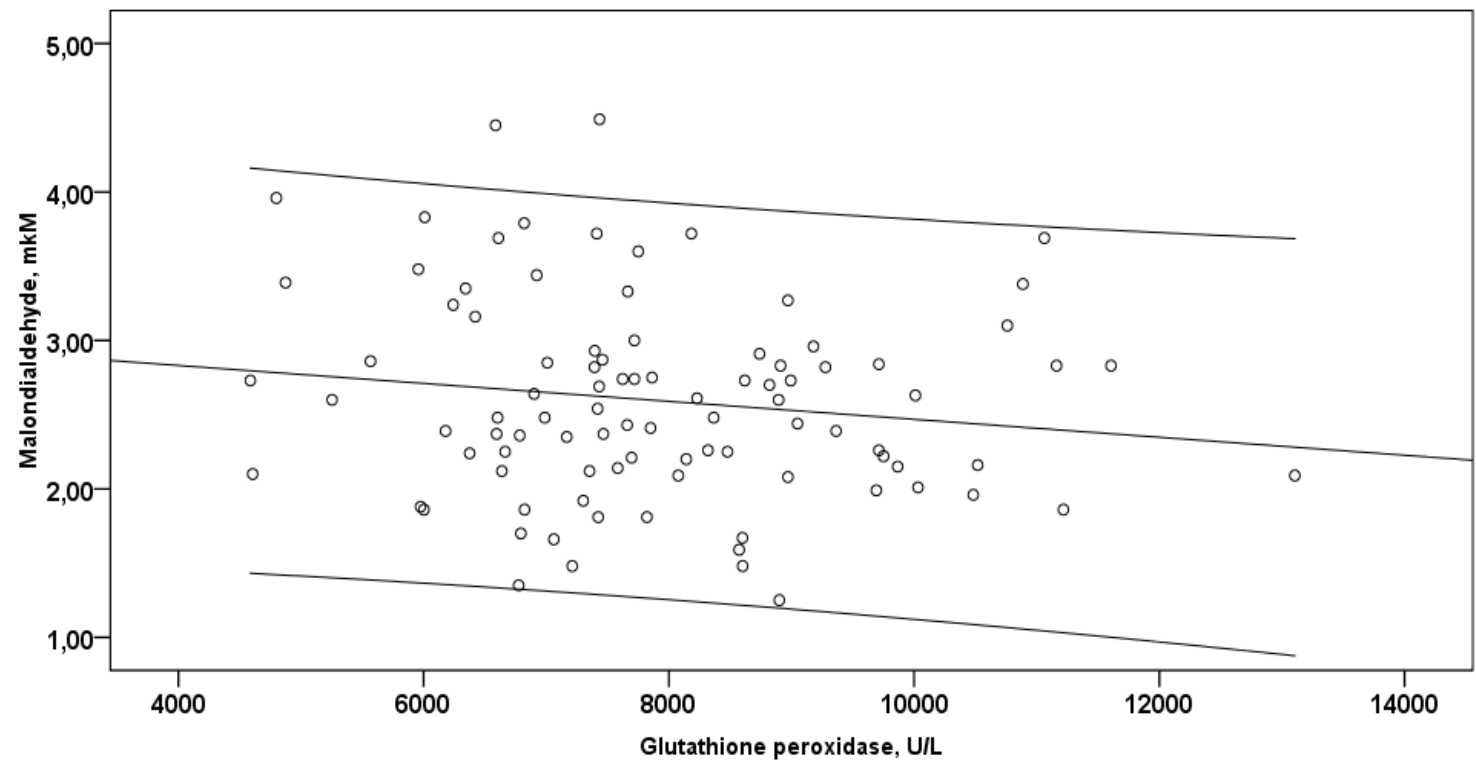

Fig. 9. Negative correlation between MDA and GPx.

MDA, malondialdehyde; GPx, glutathione peroxidase 
tation of PTSD. Our results need to be confirmed by more comprehensive and detailed further studies to support the findings we found in PTSD.

\section{ACKNOWLEDGEMENTS}

The research is supported by European Social Foundation co-financing: Project for Doctoral students support, at Rīga Stradiňs University (No. 2009/0147/1DP/1.1.2.1.2/09/IPIA/ VIAA/009). The views expressed in this article are those of the authors and do not reflect the official policy or position of the Latvian government, Latvian National Armed Forces, Medical Support Centre of Latvian National Armed Forces or any of the institutions with which the authors are affiliated. The authors state no conflict of interest. All authors read and approved the final manuscript.

\section{REFERENCES}

Adibhatla, R. M., Hatcher, J. F. (2008). Altered lipid metabolism in brain injury and disorders. Subcell. Biochem., 49, 241-68.

Anonymous (2000). Diagnostic and Statistical Manual of Mental Disorders (Revised 4th edn.). American Psychiatric Association. Washington, D.C. $\$ 309.81$.

Anwyl, R. (1991). Modulation of vertebrate neuronal calcium channels by transmitters. Brain Res. Brain Res. Rev., 16 (3), 265-281.

Bremner, J. D. (2002). Neuroimaging studies in post-traumatic stress disorder. Curr. Psychiatry Rep., 4 (4), 254-263.

Chambers, R. A., Bremner, J. D., Moghaddam, B., Southwick, S. M., Charney, D. S., Krystal, J. H. (1999). Glutamate and post-traumatic stress disorder: Towards a psychobiology of dissociation. Semin. Clin. Neuropsychiatry, 4 (4), 274-281.

Cortese, B. M., Phan, K. L. (2005). The role of glutamate in anxiety and related disorders. CNS Spectr., 10 (10), 820-830.

Del Rio, D., Stewart, A. J., Pellegrini, N. (2005). A review of recent studies on malonaldehyde as toxic molecule and biological marker of oxidative stress. Nutr. Metab. Cardiovasc. Dis., 15 (4), 316-328.

Esterbauer, H., Cheeseman, R. H. (1990). Determination of aldehydic lipid peroxidation products: Malonaldehyde and 4-hydroxynonenal. Methods Enzymol., 186, 407-421.

Ginsberg, M. D., Bogousslauvsky, J. (eds.) (1998). Cerebrovascular Disease: Pathophysiology, Diagnosis and Management. Malden: Blackwell Science. $2185 \mathrm{pp}$.

Hoge, C. W., Castro, C. A., Messer, S. C., McGurk, D., Cotting, D. I., Koffman, R. L. (2004). Combat duty in Iraq and Afghanistan, mental health problems, and barriers to care. New Engl. J. Med., 351 (1), 13-22.

Hotopf, M., Hull, L., Fear, N. T., Browne, T., Horn, O., Iversen, A., Jones, M., Murphy, D., Bland, D., Earnshaw, M., Greenberg, N., Hughes, J. H., Tate, A. R., Dandeker, C., Rona, R., Wessely, S. (2006). The health of UK military personnel who deployed to the 2003 Iraq war: A cohort study. Lancet, 367 (9524), 1731-1741.

Iversen, A. C., van Staden, L., Hughes, J. H., Browne, T., Hull, L., Hall, J., Greenberg, N., Rona, R. J., Hotopf, M., Wessely, S., Fear, N. T. (2009). The prevalence of common mental disorders and PTSD in the UK military: Using data from a clinical interview-based study. BMC Psychiatry, 9, 68.

Jourdain, P., Bergersen, L. H., Bhaukaurally, K., Bezzi, P., Santello, M., Domercq, M., Matute, C., Tonello, F., Gundersen, V., Volterra, A. (2007). Glutamate exocytosis from astrocytes controls synaptic strength. Nat. Neurosci., 10 (3), 331-339.
Moghaddam, B., Bolinao, M. L., Stein-Behrens, B., Sapolsky, R. (1994). Glucocortcoids mediate the stress-induced extracellular accumulation of glutamate. Brain Res., 655 (1-2), 251-254.

Li, Q. Y., Pedersen, C., Day, B. J., Patel, M. (2001). Dependence of excitotoxic neurodegeneration on mitochondrial aconitase inactivation. $J$. Neurochem., 78 (4), 746-755.

McDonald, S. D., Calhoun, P. S. (2010) The diagnostic accuracy of the PTSD Checklist: A critical review. Clin. Psychol. Rev., 30 (8), 976-987.

Milani, P., Gagliardi, S., Cova, E., Cereda, C. (2011). SOD1 Transcriptional and Posttranscriptional Regulation and Its Potential Implications in ALS. Neurol. Res. Int. Doi: 10.1155/2011/458427.

http://www.ncbi.nlm.nih.gov/pmc/articles/PMC3096450/

Miyamoto, Y., Koh, Y. H., Park, Y. S., Fujiwara, N., Sakiyama, H., Misonou, Y., Ookawara, T., Suzuki, K., Honke, K., Taniguchi, N. (2003). Oxidative stress caused by inactivation of glutathione peroxidase and adaptive responses. Biol. Chem., 384 (4), 567-574.

Moore, K., Roberts, L. J.2nd. (1998). Measurement of lipid peroxidation. Free Radic. Res., 28 (6), 659-671.

Nie, C. L., Wang, X. S., Liu, Y., Perrett, S., He, R. Q. (2007). Amyloid-like aggregates of neuronal tau induced by formaldehyde promote apoptosis of neuronal cells. BMC Neurosci., 8, 9.

Paglia, D. E., Valentine, W. N. (1967). Studies on the quantitative and qualitative characterization of erythrocyte glutathione peroxidase. J. Lab. Clin. Med., 70 (1), 158-169.

Pall, M. L. (2001). Common etiology of posttraumatic stress disorder, fibromyalgia, chronic fatigue syndrome and multiple chemical sensitivity via elevated nitric oxide/peroxynitrite. Med. Hypotheses, 57 (2), 139-145.

Pall, M. L. (2007). Explaining “Unexplained Illnesses": Disease Paradigm for Chronic Fatigue Syndrome, Multiple Chemical Sensitivity, Fibromyalgia, Post-Traumatic Stress Disorder, Gulf War Syndrome and Others. New York: Informa. 150 pp.

Pall, M. L., Satterlee, J. D. (2001). Elevated nitric oxide/peroxynitrite mechanism for the common etiology of multiple chemical sensitivity, chronic fatigue syndrome, and posttraumatic stress disorder. Ann. N. Y. Acad. Sci., 933, 323-329.

Pynoos, R. S., Steinberg, A. M., Layne, C. M., Briggs, E. C., Ostrowski, S. A., Fairbank, J. A. (2009). DSM-V PTSD diagnostic criteria for children and adolescents: A developmental perspective and recommendations. $J$. Trauma. Stress, 22 (5), 391-398.

Reul, J. M., Nutt, D. J. (2008). Glutamate and cortisol — a critical confluence in PTSD? J. Psychopharmacol., 22 (5), 469-472.

Riddle, J. R., Smith, T. C., Smith, B., Corbeil, T. E., Engel, C. C., Wells, T. S., Hoge, C. W., Adkins, J., Zamorski, M., Blazer, D. (2007). Millennium Cohort: The 2001-2003 baseline prevalence of mental disorders in the U.S. military. J. Clin. Epidemiol., 60 (2), 192-201.

Sapolsky, R. M. (2000). The possibility of neurotoxicity in the hippocampus in major depression: A primer on neuron death. Biol. Psychiatry, 48 (8), 755-765.

Satcher, D. (2000). Mental health: A report of the Surgeon General-Executive summary. Prof. Psychol.: Res. Practice, 31 (1), 5-13.

Trachootham, D., Lu, W., Ogasawara, M. A., Nilsa, R. D., Huang, P. (2008). Redox regulation of cell survival. Antioxid. Redox Signal,10 (8), 1343-1374.

Voicehovskis, V., Ancane, G., Voicehovska, J., Umnova, L., Skesters, A. (2011). Posttraumatic stress disorder checklist military version in Latvian language. Eur. Psychiatry, 26, 1088.

Watson, P., McFall, M., McBrine, C., Schnurr, P. P., Friedman, M. J., Keane, T., Hamblen, J. L. (2005). Best Practice Manual for Posttraumatic Stress Disorder (PTSD) Compensation and Pension Examinations. U.S. Dept of Veterans Affairs, Washington, D.C. 117 p. 
Weathers, F. W., Keane, T. M., Davidson, J. (2001). Clinician-administered PTSD scale: A review of the first ten years of research. Depress. Anxiety, 13 (3), 132-156.

Woolliams, J. A., Wiener, G., Anderson, P. H., McMurray, C. H. (1983). Variation in the activities of glutathione-peroxidase and superoxidedismutase and in the concentration of copper in the blood in various breed crosses of sheep. Res. Vet. Sci., 34 (3), 253-256.
Гаврилов В. Б., Гаврилова А. Р., Мажуль Л. М. (1987). Анализ методов определения продуктов перекисного окисления липидов в сыворотке крови по тесту с барбитуровой кислотой [Methods of determining lipid peroxidation products in the serum using a thiobarbituric acid test]. Вопросы мед. хим., 33 (1), 118-122.

Received 7 May 2012

\section{OKSIDATĪVĀ STRESA PARAMETRI POSTTRAUMATISKĀ STRESA SINDROMA RISKA GRUPAS PACIENTIEM}

Paaugstināts eksaitotoksicitātes līmenis kā atbildes reakcija uz stresoriem lieka reaktīvā skābekḷa/slāpekḷa uzkrāšanās rezultātā izraisa oksidatīvo stresu (OS). Neironālo membrānu fosfolipīdi ir īpaši jutīgi pret oksidatīvo bojājumu, rezultātā mainot signālu pārneses mehānismu. Starptautisko operāciju kontingents (SOK) tiek pakḷauts dažādiem ekstremāliem stresoriem, kas varētu izraisīt posttraumatiskā stresa sindromu (PTSS). Pieejamie pētījumu dati nav viendabīgi pēc dzimuma, rases, vecuma, uztura un dažādiem dienesta faktoriem un stresoriem, kas apgrūtina to salīdzināšanu. Pētījuma mērkis: novēertēt OS līmeni PTSS riska grupā. Pētījumā piedalījās 143 dalībnieki — Latvijas SOK, regulārais militārais personāls, vīrieši, eiropieši, kuru vidējais vecums ir 27,4 gadi, ar vienādiem uzdevumiem misijas laikā — tika izmeklēti divus mēnešus pirms un uzreiz pēc sešu mēnešu ilgas Miera uzturēšanas misijas (MUM) Afganistānā. PTSS novērtēšanai izmantota PCL-M anketa, apstiprināta latviešu valodas "militārā" versija. Asinīs noteikti OS rādītāji: glutationa peroksidāze (GPx), superoksīda dismutāze (SOD) un lipīdu peroksidāciju intensitātes rādītājs — malondialdehīds (MDA). Dati tika apstrādāti, izmantojot SPSS 20.0. MDA bāzes līmenis $(2,5582 \mu \mathrm{M})$ pēc MUM pieauga par 24,36\% (3,1815 $\mu \mathrm{M})$. GPx bāzes līmenis (8061,98 U/L) pēc MUM samazinājās par 9,35\% (7308,31 U/L). SOD bāzes līmenis (1449,20 U/gHB) pēc MUM palielinājās par 2,89\% (1491,03 U/gHB). PTSS simptomu smaguma (PCL-M punktu skaits) bāzes līmenis bija 22,90 punkti, pēc MUM tas palielinājās par 14,45\% (26,21 punkts). PTSS izplatības koeficienta (IK) bāzes līmenis bija 0,0357, pēc MUM tas pieauga par 147,06\% (0,0882). Autori secina, ka pastāv pozitīva korelācija starp OS pieaugumu, PTSS simptomu smaguma pakāpes līmeni un PTSS IK pacientiem PTSS riska grupā (SOK). PTSS IK ir atkarīgs no MDA līmeṇa un OS smaguma. Iespējams, ka OS un eksaitotoksicitātes rezultātā palielinātais brīvo radikāḷu līmenis ir veicinošs faktors PTSS klīniskās izpausmes attīstībai. 


\title{
SPECIFIC STRUCTURAL-FUNCTIONAL ROLE OF THE PRONOUNCED NEGATIVE MOLECULAR CHARGE OF THE STURGEON GONADOTROPIN $\beta$-SUBUNIT
}

\author{
Henriks Zenkevičs and Vija Vose \\ Institute of Biology, University of Latvia, Miera iela 3, Salaspils, LV-2169, LATVIA; \\ zenkevics@email.lubi.edu.Iv
}

Contributed by Henriks Zenkevičs

\begin{abstract}
Free negatively charged carboxyl groups $(\mathrm{COOH})$ were selectively modified (neutralised) in sturgeon (Acipenser güldenstädti $\mathrm{Br}$ ) gonadotropic hormone (GTH) $\beta$-subunit ( $\beta G T H)$. Eight $\mathrm{COOH}$ groups were neutralised by reaction with glycine ethyl ester. Investigation of modified $\beta G T H$ showed that specific immunoactivity with antiserum raised against standard $\beta G T H$ was completely lost. Analysis of CD spectra and the content of secondary structure elements of standard and modified $\beta G T H$ did not indicate any considerable differences. Investigation of reassociated $\alpha-\beta$ dimer comprising standard $\alpha G T H$ and modified $\beta G T H$ showed that hormonal activity was completely lost while immunoreactivity was lowered by about $30 \%$ in comparison with that of the standard subunit $\alpha-\beta$ dimer. It was concluded that eight free $\mathrm{COOH}$ groups located on the surface of $\beta G T H$ are the main structural components of the species-specific antigenic determinant groups of the subunit, but are not directly involved in either maintaining the conformation of the subunit nor in its ability to interact with the native counterpart subunit. $\mathrm{COOH}$ groups, as bearers of the negative charge located on the surface of $\beta G T H$, play a decisive role in the specific hormonal activity of GTH determined by oocyte maturation tests. Free $\mathrm{COOH}$ groups are included in the effector zones (active sites) of GTH dimer molecule responsible for the stereospecific interaction with the test-oocyte membrane hormone-sensitive binding (receptor) sites to induce the biological effects.
\end{abstract}

Key words: sturgeon fish gonadotropic hormone, $\beta$-subunit, chemical modification, CD-spectroscopy, gonadotropic and immunologic properties.

\section{INTRODUCTION}

Gonadotropic hormone (GTH, gonadotropin; $25 \mathrm{kDa}$ ) of sturgeon Acipenser güldenstädti Br., like mammalian gonadotropins, has heterodimeric molecular structure built of two complementary non-covalently bonded $\alpha$ and $\beta$ subunits ( $\alpha \mathrm{GTH}$ and $\beta \mathrm{GTH})$ (Burzawa-Gerard et al., 1980; Зенкевич и др., 1982; Zenkevičs, 1994). Individual $\alpha \mathrm{GTH}$ and $\beta$ GTH have no hormonal function. Specific biological activity typical for the native hormone is expressed only after complementary self-reassociation of the counterpart subunits in the $\alpha-\beta$ dimer structure. Reassociated from the subunits, GTH dimer usually maintains up to $100 \%$ of immunoreactivity and by about $70 \%$ of hormonal function typical of the native hormone.

In the course of comparative investigations of $\alpha \mathrm{GTH}$ and $\beta \mathrm{GTH}$ it was found that the subunits differed considerably from each other by their negative molecular charge. The electrophoretic mobility (Rf) of $\beta$ GTH (Rf $0.41-0.58$ ) in $7.5 \%$ polyacrylamide gel towards the anode was considerably higher than that of the positively charged $\alpha \mathrm{GTH}$ (Rf 0.05-0.15) (Zenkevičs, 1994; Zenkevičs et al., 2003). This indicated that $\alpha \mathrm{GTH}$ (three $\mathrm{COOH}$ groups) contains a predominance of positive molecular charge, unlike $\beta \mathrm{GTH}$. Also, as it was previously shown, $\beta$ GTH has a rigid conformation stabilised by six intramolecular S-S-bonds, while the conformationally flexible $\alpha \mathrm{GTH}$ contains only one S-S-bond (Zenkevičs, 1994).

Comparative investigation of the structural-functional role of gonadotropin subunits provided evidence that $\alpha \mathrm{GTH}$ is highly conserved within different higher and lower vertebrate species, including fish, while $\beta$ GTH differs and imparts the species-specificity to the $\alpha-\beta$ dimeric structure of the hormone (Licht et al., 1977; Pierce and Parsons, 1981; Burzawa-Gerard, 1982). The same was found in studies of properties of cross-recombinants of the counterpart subunits from systematically very distant sturgeon GTH and pig LH (Зенкевич и др.1982; Zenkevičs et al., 1999). On the basis of these findings we supposed that the pronounced negative molecular charge and the conformational rigidity of the sturgeon $\beta$ GTH may serve as a core imparting charge, three-dimensional spatial structure and the biological properties to the $\alpha-\beta$ heterodimeric molecule of the hormone. 
The aim of the present work was to employ selective chemical modification of the accessible free $\mathrm{COOH}$ groups of Asp and Glu located in the $\beta$ GTH to elucidate their possible role in maintaining the conformation of the subunit and the species-specific functional properties of the $\alpha-\beta$ dimer hormone molecule.

\section{MATERIALS AND METHODS}

Individual $\alpha \mathrm{GTH}$ and $\beta \mathrm{GTH}$ of highly purified sturgeon GTH (Зенкевич, 1992) were isolated by ion-exchange chromatography on SE-Sephadex C-25 in $0.025 \mathrm{M}$ acetate buffer at $\mathrm{pH} 4.9$, after GTH dissociation into subunits in 8 M urea according to Hennen et al. (1971).

Self-reassociation or recombination of the counterpart subunits was carried out in saline $(0.9 \% \mathrm{NaCl})$ at room temperature $(12 \mathrm{~h})$ at a total protein concentration of about $0.2 \%$, using the subunits in an equimolar ratio.

Polyacrylamide gel $(7.5 \%)$ electrophoresis (PAGE) was carried out in gel slabs $(0.4 \times 9 \times 10 \mathrm{~cm})$, using TRIS-Gly buffer solution at $\mathrm{pH} 8.9$ (Davis, 1962). Protein bands were stained with Coomassie Brilliant blue R-250.

Free $\mathrm{COOH}$ groups of $\beta \mathrm{GTH}$ were modified by glycine ethyl ester (Gly-OEt.HCl) in the presence of water soluble 1-ethyl-3(3-dimethylaminopropyl) carbodiimide (Serva) at $\mathrm{pH} 4.8$ in distilled water for $30 \mathrm{~min}$ at room temperature according to the procedure described earlier (Eyl et al., 1970; Faith and Pierce, 1975). In such a way the negative charge of free carboxyl groups of the subunit were converted to their O-glycine ethyl esters (neutralised). The reaction was stopped and modified subunit was separated from the reaction by-products on minicolumns $(0.9 \times 10.5 \mathrm{~cm})$ of Sephadex C-25 in 2\% acetic acid and lyophilised. The number of modified $\mathrm{COOH}$ groups of the $\beta \mathrm{GTH}$ was determined by amino acid analysis (Mikrotehna Praha, Czech Rep.).

To produce antisera against GTH and $\beta$ GTH young rabbits were injected subcutaneously and intramuscularly with the preparations (0.2 mg/injection) in saline using complete Freund's adjuvant (Calbiochem, USA) for ten weeks.

Double immunodiffusion tests in $1 \%$ agar gel (Bacto-agar Difco, USA) in veronal buffer (ionic strength 0.05, $\mathrm{pH} 8.6$ ) were performed by a classical procedure (Ouchterlony, 1958) using polyclonal monovalent antisera. The immunoreactivity as a percent of the standard and modified preparations was calculated as the inverse proportion between the numbers of active double dilutions.

The frog Rana temporaria L. oocyte in vitro maturation test (Thornton, 1971) was used to evaluate (to compare) the hormonal activity of the reassociated a- $\beta$ dimers comprising $\mathrm{COOH}$-modified or intact $\beta \mathrm{GTH}$. The activity was expressed as the minimal dose of the tested hormone preparation that produced $50 \%$ test-oocyte maturation (D50).
$\mathrm{CD}$ spectra of the standard and $\mathrm{COOH}$-modified $\beta \mathrm{GTH}$ were registered on a Jasco J-710 spectropolarimeter over the wavelength range from 180 to $250 \mathrm{~nm}$ at $22-25^{\circ} \mathrm{C}$, in phosphate buffer, $\mathrm{pH}$ 7.0. The spectropolarimeter was calibrated by epiandrosterone and 10-camphor-sulphonic acid standards. For recording of spectra, 0.1-0.01 cm Helma quartz cells were used. The concentration of protein in the solution was $10^{-3}-10^{-4} \mathrm{M}$. CD data are given in units of molar ellipticity per amino acid residue of an average relative molecular mass 108. The content of various secondary structures in the subunits was calculated using the CDPro CONTINLL software (Sreerama et al., 1999; Whitmore and Wallace, 2004; Lees et al., 2006). In our case the CD spectra of 29-48 proteins were used for calculation of the secondary structural elements.

\section{RESULTS}

Amino acid analysis of COOH-modified (etoxyglycylated) $\beta$ GTH showed that eight free accessible carboxyl groups located on the surface of the subunit were modified and converted to neutral ones. Also, it was found by additional amino acid analysis that the number of modified $\mathrm{COOH}$ groups in $\beta \mathrm{GTH}$ did not increase after 20 minutes of interaction with the modifying reagent. The modification (neutralisation) of $\beta \mathrm{GTH}\left(\beta \mathrm{GTH} \mathrm{mod}_{\mathrm{mod}}\right)$ significantly decreased its electrophoretic mobility(Rf ) 0.03-0.12, in comparison with that of standard intact $\beta \mathrm{GTH}_{\mathrm{st}}(0.41-0.58)$ (Fig. 1).

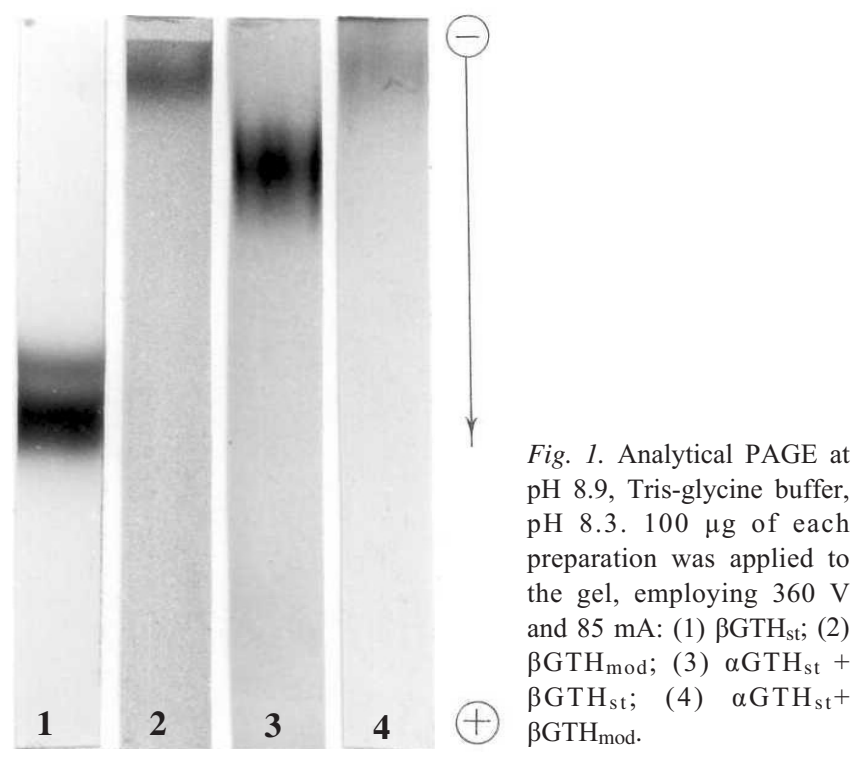

Comparison of the immunoreactivity of $\beta \mathrm{GTH}_{\bmod }$ and $\beta \mathrm{GTH}_{\text {st }}$ in double immunodiffusion tests using $\beta \mathrm{GTH}_{\mathrm{st}}$ antiserum (stepwise two-fold dilutions of the tested antigens) showed that $\beta \mathrm{GTH}_{\text {mod }}$ did not interact with the antibodies raised against standard subunit $\beta \mathrm{GTH}_{\mathrm{st}}$.

$\beta \mathrm{GTH}_{\text {st }}$ was recombined with intact $\alpha \mathrm{GTH}$ to produce dimer $\alpha \mathrm{GTH}_{\mathrm{st}}+\beta \mathrm{GTH}$ mod by self-reassociation of both counterpart subunits. This approach was used to elucidate the possible structure-functional impact caused by neutralisation of the negative molecular charge of the subunit on 
both the specific hormonal function and immunoreactivity of the dimer struture $\alpha \mathrm{GTH}_{\mathrm{st}}+\beta \mathrm{GTH}_{\text {mod }}$, in comparison with that of the control dimer $\alpha \mathrm{GTH}_{\mathrm{st}}+\beta \mathrm{GTH}_{\mathrm{st}}$ (Table 1). As seen, by the biological properties of the recombined dimers in the comparative double immunodiffusion test with the standard GTH antiserum (Table 1), the substitution of the native $\beta$ GTH in the $\alpha-\beta$ dimer by the $\beta \mathrm{GTH}_{\text {mod }}$ lowered the dimer immunoreactivity by $25 \%$ while the specific hormonal function lacked completely.

Table 1

BIOLOGICAL PROPERTIES OF REASSOCIATED $\alpha-\beta$ DIMERS COMPRISING STANDARD AND COOH-MODIFIED $\beta$-SUBUNIT

\begin{tabular}{ccccc}
\hline Preparation & Antiserum & $\begin{array}{c}\text { Immunore- } \\
\text { activity, } \%\end{array}$ & $\begin{array}{c}\text { Hormonal } \\
\text { activity, } \%\end{array}$ \\
\hline$\alpha$ GTHst $+\beta$ GTHst & GTH & 100 & 100 \\
$\alpha$ GTHst $+\beta$ GTHmod & GTH & 75 & 0
\end{tabular}

st - standard; mod. - modified COOH-groups

Comparative PAGE of $\alpha \mathrm{GTH}_{\mathrm{st}}+\beta \mathrm{GTH}_{\mathrm{st}}$ and $\alpha \mathrm{GTH}_{\mathrm{st}}+$ $\beta \mathrm{GTH}_{\text {mod }}$ indicated that Rf of $\alpha \mathrm{GTH}_{\mathrm{st}}+\beta \mathrm{GTH}_{\text {mod }}$ considerably decreased toward the anode ( $\operatorname{Rf} 0.02-0.13$ ) in comparison with that of the standard subunit dimer $\alpha \mathrm{GTH}_{\mathrm{st}}+$ $\beta \mathrm{GTH}_{\mathrm{st}}(0.14-0.28)$ (Fig. 1). Each of the compared reassociated dimers formed a massive and compact electrophoretic band. Also, Rf of $\beta G_{\text {THod }}(0.03-0.11)$ decreased sharply in comparison with that of $\beta \mathrm{GTH}_{\mathrm{st}}(0.41-0.58)$ (Fig. 1).

CD spectra (Fig. 2) indicate that the conformation of $\beta \mathrm{GTH}_{\mathrm{st}}$ and $\beta \mathrm{GTH} \mathrm{Hod}_{\text {mod }}$ is characterised by a negative band around 193-197 $\mathrm{nm}$ and a shoulder (or two minor negative bands) at 205 and $215 \mathrm{~nm}$ that is weakly expressed. The negative Cotton effect around $195 \mathrm{~nm}$ is close to the well known negative band of the random coil at $198 \mathrm{~nm}$, while the shoulder and the negative band (around 205 and 215 $\mathrm{nm}$ ) might be due to the contribution of the $\beta$-structures influenced by minor content of the $\alpha$-helix (Lees et al., 2006).

The results of the calculations and the shape of measured CD spectra indicated that there were no considerable distinctions between the content of various secondary structure elements of $\beta \mathrm{GTH}_{\text {mod }}$ and $\beta \mathrm{GTH}_{\text {st }}$ (Table 2).

\section{DISCUSSION}

Electrophoresis of $\beta \mathrm{GTH}_{\text {mod }}$ showed that etoxyglycylation of eight free accassible $\mathrm{COOH}$ groups resulted in a sharply declined negative charge of the modified subunit. PAGE indicated that $\mathrm{Rf}$ of the $\beta \mathrm{GTH}_{\text {mod }}(0.03-0.12)$, unlike the $\beta$ $\mathrm{GTH}_{\mathrm{st}}(0.41-0.58)$, was very close to that of the positively charged $\alpha \mathrm{GTH}_{\mathrm{st}}(0.05-0.15)$ (Zenkevics et al., 2003). Immunodiffusion tests with the $\beta \mathrm{GTH}_{\mathrm{st}}$ antiserum showed

Table 2

CONTENT OF SECONDARY STRUCTURAL ELEMENTS (\%) OF STANDARD AND COOH-MODIFIED $\beta$-SUBUNITS

\begin{tabular}{l|c|c|c|c}
\hline Preparation & $\alpha^{*}$ & $\beta^{*}$ & $\beta \mathrm{t}^{*}$ & $\mathrm{R}^{*}$ \\
\hline$\beta \mathrm{GTHst}$ & 1.9 & 24.7 & 15.2 & 58.2 \\
$\beta$ GTHmod & 2.3 & 24.2 & 14.3 & 59.2
\end{tabular}

${ }^{*} \alpha, \alpha$-helix; $\beta, \beta$-strand; $\beta_{\mathrm{t}}, \beta$-turn; $\mathrm{R}$ - random coil; st, standard; mod, modified $\mathrm{COOH}$-groups.

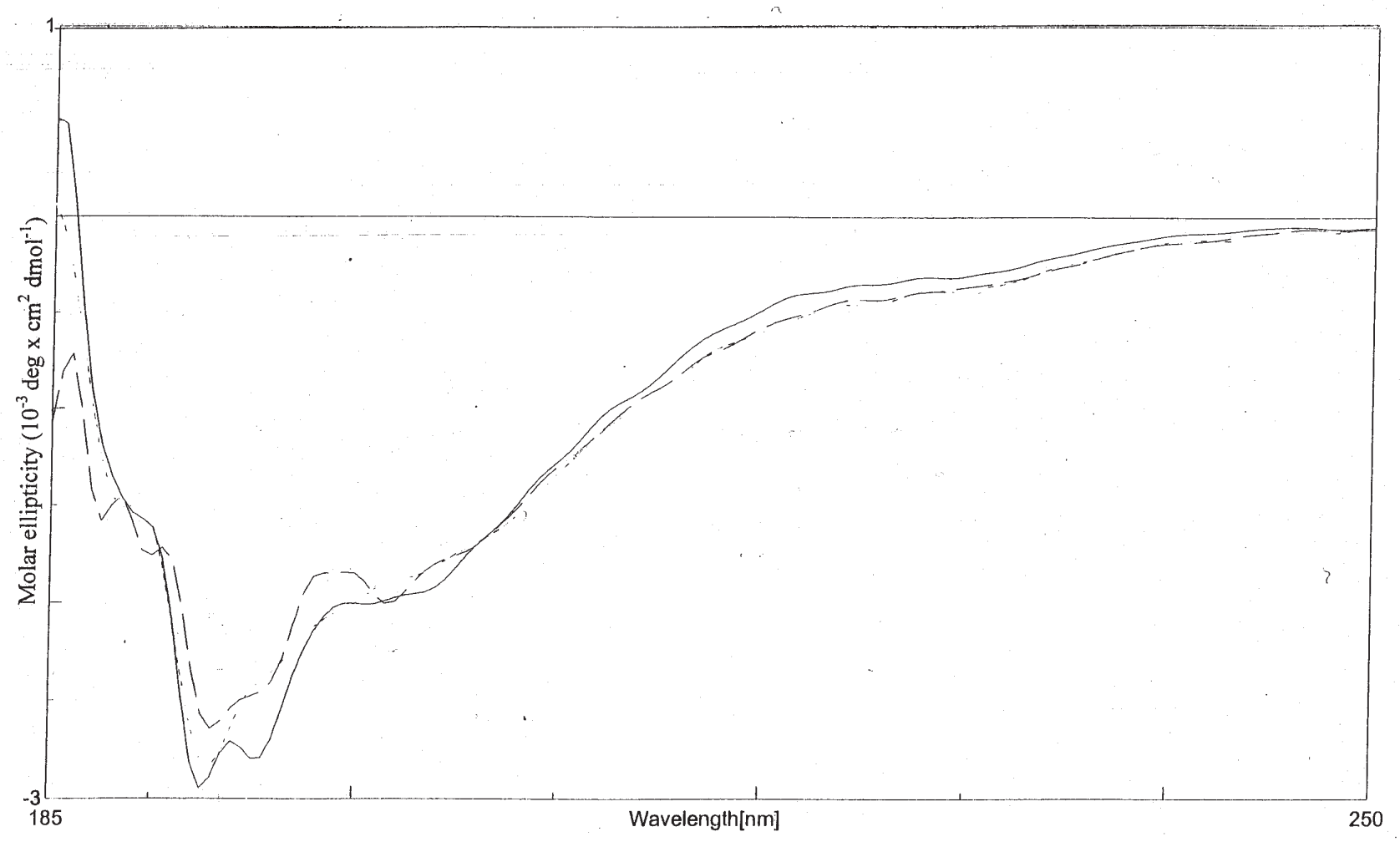

Fig. 2. CD spectra of sturgeon GTH $\beta_{\text {st }}(\longrightarrow), \beta_{\bmod }(---)$. 
that $\beta \mathrm{GTH}_{\text {mod }}$ was completely inactive. In other words, antibodies specific for $\beta \mathrm{GTH}_{\text {st }}$ cannot recognise $\beta \mathrm{GTH}_{\text {mod. }}$ This quite clearly shows that the neutralisation of carboxyl groups may play a considerable role in sustaining the structure of the antigenic determinant groups of the subunit responsible for the stereospecific interaction with the active

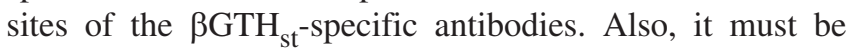
taken in consideration that the neutralisation of eight $\mathrm{COOH}$ groups located on the surface of the subunit may also produce a considerable redistribution of the surface charge of the modified subunit, which may cause an indirect impact on the thre-dimensional spatial structure and cause some deterioration in the site (determinants) configuration responsible for the immunospecificity of the subunit. This may account for lack of the specific immunoreactivity of the $\beta \mathrm{GTH}_{\text {mod }}$ typical of the $\beta \mathrm{GTH}_{\text {st. }}$

CD-spectroscopy studies showed that the removal of the negative charges of $\beta \mathrm{GTH}_{\mathrm{st}}$ did not produce any considerable shifts or appreciable distortion in spatial structure of the modified subunit, in comparison with that of the intact standard subunit (Fig. 2, Table 2). In order to determine whether $\beta \mathrm{GTH}_{\text {mod }}$ can interact with its counterpart $\alpha \mathrm{GTH}_{\mathrm{st}}$ to form stable $\alpha-\beta$ dimer structure typical of GTH, both counterpart subunits were submitted to self-reassociation. Investigation of the obtained dimer $\alpha \mathrm{GTH}_{\mathrm{st}}+\beta \mathrm{GTH}_{\text {mod }}$ in PAGE tests showed quite clearly that the modified dimer was stable (Fig. 1). This also indicated that $\beta G T H_{\text {mod }}$ on the whole retained its native configuration and complementarity of the sites responsible for subunit-subunit interaction (reassociation), structural stability of the $\alpha-\beta$ heterodimer and stereospecificity of its active sites responsible for the specific interaction with the native counterpart $\alpha \mathrm{GTH}$. Based on this finding, it is apparent that modified $\mathrm{COOH}$ groups of $\beta \mathrm{GTH}$ are not directly involved in the subunitsubunit interactions and in the formation of the three-dimensional functionally active structure recogniseable by active sites of standard GTH antibodies. However, even minimal distortions of the three-dimensional structure of stereocomplementary interacting protein structures may produce certain shifts in their specific biological function.

Immunoreactivity tests with standard GTH antiserum in double diffusion reactions showed that immunoreactivity of the hybrid molecule $\alpha \mathrm{GTH}_{\mathrm{st}}+\beta \mathrm{GTH}_{\text {mod }}$ decreased at least by $25 \%$ in comparison with that of the control $\alpha \mathrm{GTH}_{\mathrm{st}}+$ $\beta \mathrm{GTH}_{\mathrm{st}}$ (Table 1). Immunoidentity tests using standard GTH antiserum indicated partial identity (spur) between these two preparations. This means that the complementary interaction of the $\beta \mathrm{GTH}_{\text {mod }}$ with the $\alpha \mathrm{GTH}_{\text {st }}$ produced a certain incompatibility of the antigenic determinant groups in obtained hybrid dimer $\alpha-\beta$ structure, in comparison with that of the standard dimer.

The present results show that the neutralised eight negatively charged free carboxyl radicals were not critical for the stability of the native three-dimensional spatial structure of the subunit necessary for the recognition of the species-stereospecific interaction sites of the standard $\alpha \mathrm{GTH}$ to form stable dimer structure typical for the hormone On the other hand, comparison of the immunoreactivity of $\beta \mathrm{GTH}_{\mathrm{st}}$ and $\beta \mathrm{GTH}_{\text {mod }}$ using $\beta \mathrm{GTH} \mathrm{st}_{\mathrm{st}}$ antiserum indicated that the modified $\beta$ GTH was inactive. This showed quite clearly that the free $\mathrm{COOH}$ radicals are critical for the immunologic activity of the $\beta \mathrm{GTH}$. Based on this finding, it is apparent that $\mathrm{COOH}$ radicals may be inferred to be essential structure elements of the antigenic determinant groups of the $\beta \mathrm{GTH}$.

The comparative evaluation of hormonal activity showed (Table 1) that the modified recombinant $\alpha \mathrm{GTH}_{\mathrm{st}}+$ $\beta \mathrm{GTH}_{\text {mod }}$ was completely inactive.

This indicates that eight free $\mathrm{COOH}$ groups, located on the surface of the subunit, have direct importance for the specific hormonal function and are much less critical for the immunologic function of the dimer structure of the hormone.

The ability of the standard GTH antiserum to interact with the recombinant $\alpha$ GTHst $+\beta$ GTHmod in the immunospecific double diffusion tests indicated that the modification of the eight $\mathrm{COOH}$ groups of the $\beta \mathrm{GTH}$ did not prevent the formation of the $\alpha-\beta$ dimer structure typical of the hormone and are recognisable by the active sites of standard GTH antibodies.

However, these data allow to conclude that the modified $\mathrm{COOH}$ groups are not directly involved in the subunitsubunit interactions and in the formation of functionaly active three-dimensional structure of the recombinant.

The conformation of the investigated recombinant $\alpha \mathrm{GTH}$ st $+\beta$ GTHmod, comprising $\beta$ GTHmod, is quite closely related to that of the standard GTH, as indicated by antigen-antibody immunospecific interaction that necessitates quite close stereospecific fit between the antigenic determinant groups of the modified antigen $\alpha$ GTHst $+\beta$ GTHmod and the standard GTH in immunorection with active sites of the standard GTH antibodies.

Regarding hormonal activity, even minimal distortions of the three-dimensional structure of protein-like bioregulators may alter their functional (effector) group disposition on the molecular surface, causing considerable shifts in their ability to interact with the hormone-specific receptor sites of the cell membrane to induce the hormonal effects. The results also support our previous findings that the immunological properties of sturgeon GTH are much less vulnerable than its specific hormonal function (Зенкевич и др., 1992; Зенкевич, 1992).

Based on these findings it can be concluded that the eight free $\mathrm{COOH}$ groups located on the surface of $\beta \mathrm{GTH}$ are main structural components of the species-specific antigenic determinant groups of the subunit, but are not directly involved in both maintaining the conformation of the subunit and in its ability to interact with the native counterpart subunit. $\mathrm{COOH}$ groups of $\beta \mathrm{GTH}$, as bearers of the main negative charge potential located on the surface of the hormone molecule, play a decisive role in the specific hormonal ac- 
tivity of GTH at the hormone-competent cell level. The obtained results showed that free $\mathrm{COOH}$ groups are directly involved in the formation of the effector zones (active sites) of GTH dimer molecule responsible for the stereospecific interaction with the test-oocyte membrane hormone-sensitive binding (receptor) sites to induce the gonadotropic effects. Based on these findings, it is apparent that the pronounced negative molecular charge and the conformational rigidity of the $\beta$ GTH may serve as a molecular core imparting the molecular charge disposition and species specific features of the three-dimensional spatial structure of the $\alpha \mathrm{GTH}$ essential for the gonadotropic function of the hormone molecule.

\section{ACKNOWLEDGEMENTS}

This work was supported by the Latvian Council of Science, grant 09.1550 .

\section{REFERENCES}

Burzawa-Gerard, E. (1982). Chemical data on pituitary gonadotropins and their implication to evolution. Canad. J. Fisheries Aquat. Sci., 39, 80-91.

Burzawa-Gerard, E., Dufour, S., Fontaine, Y. A. (1980). Relations immunologiques entre les hormones glycoproteiques hypophysaires de poissons et de mammiferes ainsi qu'entre leurs sous-unites $\alpha$ et $\beta$. Gen. Comp. Endocrinol., 41, 199-211.

Davis, B. J. (1962). Disc Electrophoresis. Nr. 4. Rochester, N.Y.: Eston Kodak Co. 15 pp.

Eyl, A., Inagami, T. (1970). Modification of carboxyl groups in the active site of trypsin. Biochim. Biophys. Res. Commun., 38, 149-155.

Faith, M. R., Pierce, J. G. (1975).The carboxylic acid groups of bovine luteinizing hormone (The effect of their modification on receptor site binding and subunit interaction). J. Biol. Chem., 250 (17), 6923-6929.

Hennen, G., Prusik, Z., Maghuin-Rogister, G. (1971). Porcine luteinizing hormone and its subunits. Eur. J. Biochem., 18, 376-383.

Lees, J. G., Miles, A. J., Wien, F., Wallace, B. A. (2006). A reference database for circular dichroism spectroscopy covering fold and secondary structure space. Bioinformatics, 22 (16),1955-1962.
Licht, P., Papkoff, H., Farmer, S. W., Muller, C. H., Tsui, H. W., Crews, D. (1977). Recent Progr. Hormone Res., 33, 169-248.

Ouchterlony, O. (1958). Diffusion-in-gel methods for immunological analyses. Progr. Allergy, 5, 1-6.

Pierce, J. G., Parsons, T. F. (1981). Glycoprotein hormones: Structure and function. Ann. Rew. Biochem., 50, 465-495.

Sreerama, N., Venyaminov, S. Y., Woody, R. W. (1999). Estimation of the number of alpha-helical and beta-strand segments in proteins using circular dichroism spectroscopy. Protein Sci., 8, 370-380.

Thornton, V. F. (1971). A bioassay for progesterone and gonadotropins based on meiotic division of Xenopus oocytes in vitro. Gen. Comp. Endocrinol., 16, 599-605.

Whitmore, L., Wallace, B. A. (2004). DICHROWEB, an online server of protein secondary structure analyses from circular dichroism spectroscopic data. Nucleic Acid Res., 32, W668-W673.

Zenkevičs, H. (1994). Fish gonadotropic hormone: Structural-functional investigations. Proc. Latvian Acad. Sci., Section B, 48 (5/6), 82-88.

Zenkevičs, H., Vose, V., Būcena, A. (1999). Substitution of native subunits in sturgeon gonadotropin. Proc. Latvian Acad. Sci., Section B, 53 (5), 261-264.

Zenkevičs, H., Vose, V., Būcena, A. (2003). Functional role of tryptophan residues in sturgeon gonadotropic hormone. Proc. Latvian Acad. Sci., Section B, 57 (5), 187-190.

Зенкевич Г. А. (1992). Гонадотропныцй гормон рыб: получение и свойства [Fish Gonadotropic Hormone: Isolation and Properties]. Рига: Зинатне. 224 с. (in Russian).

Зенкевич Г. А., Арбатский Н. П., Сланке В. П., Желтова А. О., Деревицкая В. А. (1992). Структура углеводных цепей димерной молекулы и отдельных субъединиц гонадотропина русского осетра [Structure of the carbohydrate chains of the dimeric molecule and individual subunits of the Russian sturgeon gonadotropin]. Биоорган. хим., 18, 226-234 (in Russian).

Зенкевич Г. А., Кирстукас И. П., Лаце 3. М., Сланке В. П., Валдман А. Р. (1982). Получение субъединиц гонадотропного гормона русского осетра (Acipenser güldenstädti Br.) и севрюги (Acipenser stellatus Pall.) и оценка их гормональной активности и иммунохимических свойств до и после реассоциации [Isolation of Russian sturgeon and starred sturgeon gonadotropin subunits and investigation of its hormonal and immunochemical properties before and after reassociation]. Доклады Академии наук СССР, 268 (1), 249-251 (in Russian).

\section{STORES GONADOTROPĪNA IZTEIKTI NEGATĪVI LĀDĒTĀS $\beta$ SUBVIENĪBAS İPAŠĀ STRUKTŪRFUNKCIONĀLĀ LOMA}

Stores $\beta$ subvienībai $(\beta \mathrm{GTH})$, atškirīibā no $\alpha \mathrm{GTH}$, ir raksturīgs izteikti negatīvs molekulārais lādiṇš. Selektīvās k̦īmiskās modifikācijas cel̦ā $\beta$ GTH izdevās neitralizēt visas astoṇas brīvās COOH grupas. Modificētā subvienība pilnībā zaudēja spēju mijiedarboties ar standartsubvienības antivielām. Krasi samazinājās tās elektroforētiskā virzība uz anodu. Taču CD spektroskopijas pētījumi liecināja, ka modifikācija nav radījusi būtiskas izmainas $\beta$ GTH otrējā struktūrā. Modificētā $\beta$ GTH spēja reasociēties ar natīvo $\alpha$ GTH, veidojot elektroforētiski stabilu $\alpha-\beta$ dimēru, kura imūnreaktivitāte salīdzinājumā ar intakto subvienību $\alpha-\beta$ dimēru izrādījās par $30 \%$ zemāka imūntestos ar GTH antivielām. Taču tās hormonaktivitāte bija pilnībā zudusi. Secināts, ka brīvām COOH grupām ir būtiska nozīme $\beta$ GTH antigēno determinantu struktūras veidošanā, bet to loma subvienību specifiskās komplementārās mijiedarbības procesā nav īpaši nozīmīga. Pētījuma rezultāti rāda, ka brīvajām $\mathrm{COOH}$ grupām ir ìpaša nozīme hormona dimērmolekulas efektorajās zonās jeb aktīvajos centros, kas nodrošina GTH molekulas stereospecifisko mijiedarbību ar olšūnu membrānreceptoriem, tādējādi inducējot gonadotropā procesa norisi olšūnās. 


\title{
CONCENTRATION-DEPENDENT ANTIOXIDANT/PRO-OXIDANT ACTIVITY OF ASCORBIC ACID IN CHICKENS
}

\author{
Nadežda Bērziṇa*, Jurijs Markovs**, Mirdza Apsīte*, Svetlana Vasiljjeva*, \\ Nataljja Basova*, and Gaḷina Smirnova* \\ * Institute of Biology, University of Latvia, Miera iela 3, Salaspils, LV-2169, LATVIA; \\ nemo.berzina@email.lubi.edu.Iv \\ ** Faculty of Medicine, University of Latvia, Šarlotes iela 1A, Rīga, LV-1006, LATVIA
}

Communicated by Henriks Zenkevičs

\begin{abstract}
The effects of ascorbic acid supplementation on biomarkers of oxidative stress, cadmium accumulation in organs, immune system activity and kidney function in chickens were investigated. The treatment groups of chickens were fed either plain diet or diet supplemented with ascorbic acid at 100, 500, 1000 and $2000 \mathrm{mg} / \mathrm{kg}$ for four weeks. Liver and kidney tissues were assayed for cadmium concentration, and the hepatic levels of ascorbic acid and dehydroascorbic acid (DHAA; the oxidised form), malondialdehyde, glutathione, activity of glutathione peroxidase, blood serum uric acid, creatinine, lysozyme and circulating immune complexes were measured. Supplementation with a high dose of ascorbic acid (1000 and $2000 \mathrm{mg} / \mathrm{kg}$ in the diet) caused an imbalance between pro-oxidative and antioxidative activities, and induced a suppressive effect on innate immunity. The results suggest that oxidative stress compromises renal function. We observed that ascorbic acid increased cadmium accumulation in a dose-dependent manner.
\end{abstract}

Key words: ascorbic acid, oxidative stress, cadmium, chicken.

\section{INTRODUCTION}

Ascorbic acid (AA) has antioxidant effects and can protect tissue against damage caused by strong oxidants that contain reactive oxygen species. AA forms a redox system and is also connected with the glutathione (GSH) system (Winkler et al., 1994; Kohen and Nyska, 2002). Oxidative stress decreases AA concentration in tissues, and therefore, supplementation of AA is required in diet. However, AA may alter the pro-oxidant-antioxidant balance in poultry, depending on its dose and the concentrations of redox-active transition metal ions (iron, cadmium, copper, lead, mercury and chromium) in tissue (Poljsak et al., 2005). Increased oxidative stress has been implicated in heavy metal overload conditions. For example, cadmium induces a significant increase in reactive oxygen species (Gobe and Crane, 2010).

Cadmium is a toxic metal and targets the liver and kidneys following acute and chronic intoxication, which may induce cell death via apoptosis. Dietary supplementation with antioxidants is an important consideration for limiting renal oxidative stress and progression of chronic kidney disease (Brown, 2008). After necrotic cell death, a burst of uric acid is released from the cells, which induces acute inflammatory responses (Kono et al., 2010).
Inflammation is triggered by circulating immune complexes (CIC) that enter the tissue (Clynes et al., 1999). Uric acid is normally excreted from the body via the kidneys (80\%) and intestines (20\%). Heavy metal poisoning increases the concentration of uric acid in human serum, whereas therapeutic dosages of AA facilitate the excretion of uric acid (Mitch et al., 1981). The concentration of serum creatinine can also be used to estimate renal dysfunction (Eisner et al., 2010).

Only scanty and contradictory information is available concerning the oxidative stress response of metabolic organs to a range of doses of ascorbic acid (Duarte and Lunec, 2005; Poljsak et al., 2005).

The aim of the present study was to determine the effect of dietary supplementation of ascorbic acid, using a wide range of doses, on the content of a heavy metal, such as cadmium, in the liver and kidney, and on the oxidative status, innate immunity and kidney function markers in chicks.

\section{MATERIALS AND METHODS}

Animals. New-hatched Lohmann brown cockerels were obtained from the Latvian poultry company BALTICOVO. 
Experimental design. All of the experimental procedures were approved by the Animal Ethics Committee of the Food and Veterinary Service (Riga, Latvia, authorisation reference number 13, from 22 December 2008). The chickens were housed in cage units with free access to food and water. The experiment was conducted using one- to thirtyday-old chickens.

The animals were divided into five groups of 25 animals each. Control group chickens (Control) received a basal wheat-barley diet containing all of the necessary nutrients without any ascorbic acid supplementation. The chickens of the other four groups were provided with the same basal diet that was supplemented with one of the following doses of ascorbic acid, AA (Sigma-Aldrich, St. Louis, Missouri, USA): $100 \mathrm{mg} / \mathrm{kg}$ (100 AA, second group), $500 \mathrm{mg} / \mathrm{kg}$ (500 AA, third group), $1000 \mathrm{mg} / \mathrm{kg}$ (1000 AA, fourth group), and $2000 \mathrm{mg} / \mathrm{kg}$ (2000 AA, fifth group).

Physiological and biochemical study. At the end of the experiment, the cockerels were sacrificed by decapitation in accordance with the recommendation for the euthanasia of experimental animals of the European Convention (Close et al., 1997). Peripheral blood samples, liver and kidney were collected for analysis.

Lipid peroxidation in chicken tissues was determined by thiobarbituric reaction. The results were expressed as $\mu \mathrm{mol}$ malondialdehyde (MDA) per gram of fresh tissue (Surai et al., 1996). The total vitamin C, and dehydroascorbic acid (DHAA) concentrations in chick liver were estimated by the 2.4-dinitrophenylhydrazine colorimetric method; the reduced ascorbic acid (AA) content was calculated by subtraction (Surai et al., 1999). The glutathione level in the liver was measured spectrophotometrically using 5.5-ditiobis-para-nitro-benzoic acid (Beutler et al., 1963). The activity of glutathione peroxidase (GSH-Px, EC 1.11.1.9) in liver was assayed by the coupled enzyme procedure using hydrogen peroxide as the substrate (Pinto and Bartley, 1969). The concentration of cadmium in chicken liver and kidney were determined using atomic absorption spectrophotometry (Anonymous, 2000). Uric acid concentration in blood serum was estimated by the carbonate method using colorimetric procedure (Eichhorn et al., 1961). The creatinine content in blood serum was measured using the colorimetric method with alkaline picrate, based on the Jaff reaction (commercial biochemical kit, Divi-Dent). The indices of non-specific humoral immune responses were examined in chickens immunized intraperitoneally with $0.1 \mathrm{ml} 10 \%$ sheep red blood cells in PBS seven days before the end of experiment. Serum lysozyme level was estimated using a mo dified bacteriolytic method (Грант и др., 1973) based on absorptiometric determination of the decrease in turbidity of a suspension of Micrococcus lysodeikticus, as described by Shugar (1952). Nonspecific circulating immune complexes in serum were estimated spectrophotometrically after precipitation with polyethyleneglycol 6000 (Riha, 1979).

Statistical analysis. The data were expressed as the means \pm SD. The differences between the control and four experimental groups were analysed using analysis of variance (ANOVA) followed by the Dunnett's test and Tukey's post hoc test. A $P$ value of 0.05 was considered statistically significant.

\section{RESULTS}

The level of reduced AA and DHAA in chick liver (Fig. 1) depends on the AA dose in diet. The reduced AA content relative to the DHAA content decreased more than two times in chickens receiving high doses of AA (1000 and $2000 \mathrm{mg} / \mathrm{kg}$ of diet). Tables 1 and 2 show that the ascorbic acid concentration in the diet is correlated with the accumulation of cadmium in liver and kidney. The concentration of cadmium in the liver increased when ascorbic acid was supplemented in the diet at doses of $500(P<0.0002), 1000$ $(P<0.0001)$ and $2000 \mathrm{mg} / \mathrm{kg}(P<0.0001)$. The content of this heavy metal in kidney significantly increased when ascorbic acid was added to the diet at a dose of $2000 \mathrm{mg} / \mathrm{kg}$ $(P<0.02)$. Moreover, the ascorbic acid at doses of 500 $\mathrm{mg} / \mathrm{kg}$, and particularly at 1000 and $2000 \mathrm{mg} / \mathrm{kg}$, significantly decreased the level of GSH. However, ascorbic acid decreased the activity of GSH-Px at doses of 1000 and 2000

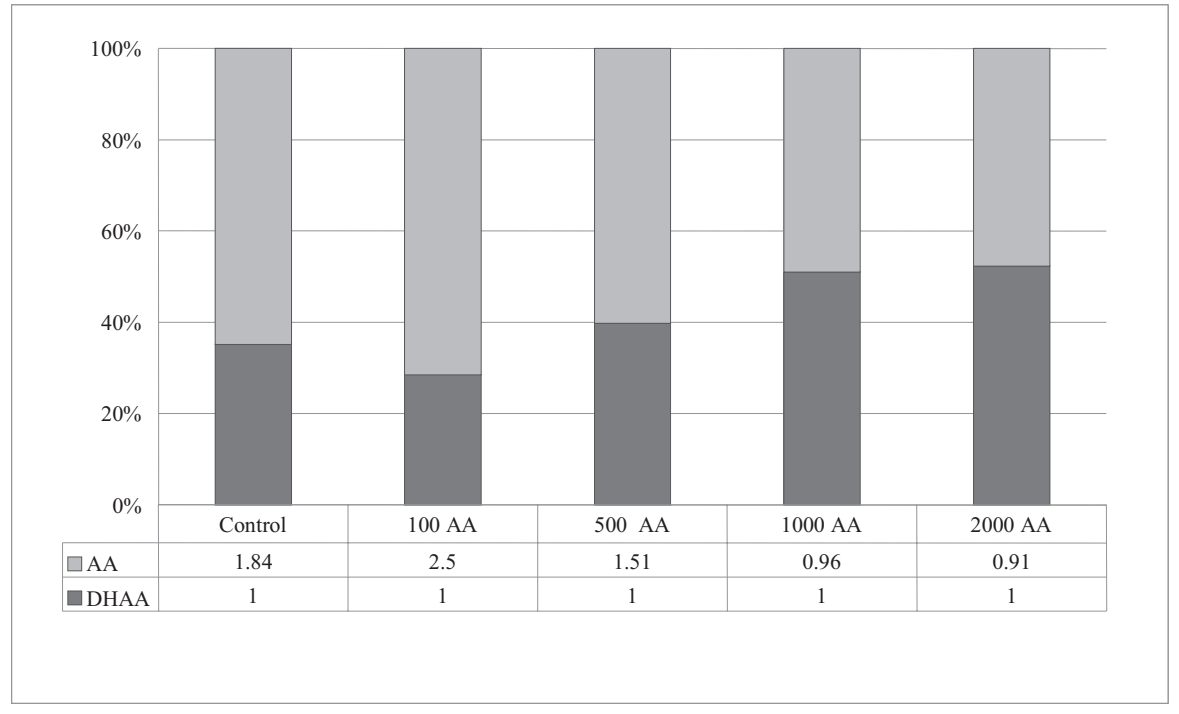

Fig. 1. Proportion of dehydroascorbic acid and reduced ascorbic acid to total vitamin $\mathrm{C}$ in liver of chickens receiving diet with different ascorbic acid levels from hatching to 30 days of age 
HEPATIC CADMIUM CONCENTRATION, GLUTATHIONE LEVEL, GLUTATHIONE PEROXIDASE ACTIVITY AND MALONDIALDEHYDE FORMATION IN CHICKENS THAT RECEIVED DIETS SUPPLEMENTED WITH ASCORBIC ACID (mean \pm SD)

\begin{tabular}{c|c|c|c|c}
\hline \multicolumn{1}{c|}{ Group } & $\begin{array}{c}\mathrm{Cd}, \\
\mathrm{gg} / \mathrm{g}\end{array}$ & $\begin{array}{c}\mathrm{GSH}, \\
\mu \mathrm{mol} / \mathrm{g}\end{array}$ & $\begin{array}{c}\mathrm{GSH}-\mathrm{Px}, \\
\mu \mathrm{mol} \cdot \mathrm{GSH} / \\
\mathrm{min} / \mathrm{g}\end{array}$ & $\begin{array}{c}\mathrm{MDA}, \\
\mu \mathrm{mol} / \mathrm{g}\end{array}$ \\
\hline 1. Control & $0.22 \pm 0.02$ & $4.83 \pm 0.27$ & $4.46 \pm 0.46$ & $29.56 \pm 1.68$ \\
2. $100 \mathrm{AA}$ & $0.26 \pm 0.04$ & $4.92 \pm 0.36$ & $4.49 \pm 0.54$ & $32.05 \pm 1.42$ \\
3. 500 AA & $0.38 \pm 0.06^{*}$ & $4.17 \pm 0.18^{* * *}$ & $4.37 \pm 0.27$ & $31.51 \pm 3.45$ \\
4. 1000 AA & $0.40 \pm 0.05 * *$ & $3.91 \pm 0.23 * *$ & $3.30 \pm 0.15 * *$ & $34.68 \pm 1.47 *$ \\
5. 2000 AA & $0.46 \pm 0.03 * *$ & $3.75 \pm 0.31 * *$ & $3.20 \pm 0.11 * *$ & $42.17 \pm 3.73 * *$ \\
\hline
\end{tabular}

Cd, cadmium; AA, ascorbic acid; GSH, glutathione; GSH-Px, glutathione peroxidase and MDA, malondialdehyde. Statistically significant differences from the control group: $* P=0.0002$; $* * P<0.0001$ and $* * * P=$ 0.0006 .

Table 2

CONCENTRATION OF CADMIUM AND PARAMETERS OF RENAL FUNCTION IN CHICKENS THAT RECEIVED DIET SUPPLEMENTED WITH ASCORBIC ACID $($ MEAN \pm SD)

\begin{tabular}{l|c|c|c}
\hline \multicolumn{1}{c}{ Group } & $\begin{array}{c}\text { Cd, } \mu \text { g/g wet wt of } \\
\text { kidney }\end{array}$ & $\begin{array}{c}\text { Uric acid, } \mu \mathrm{mol} / 1 \\
\text { of blood serum }\end{array}$ & $\begin{array}{c}\text { Creatinine, } \mu \mathrm{mol} / 1 \\
\text { of blood serum }\end{array}$ \\
\hline 1. Control 1 & $0.20 \pm 0.00$ & $131.59 \pm 18.33$ & $67.40 \pm 2.31$ \\
2.100 AA & $0.20 \pm 0.00$ & $116.59 \pm 5.82$ & $57.12 \pm 0.29^{* * * *}$ \\
3.500 AA & $0.26 \pm 0.02$ & $117.42 \pm 12.49$ & $60.73 \pm 0.25^{* * *}$ \\
4. 1000 AA & $0.30 \pm 0.04$ & $167.38 \pm 27.48^{*}$ & $119.51 \pm 6.54^{* * *}$ \\
5. 2000 AA & $0.32^{*} \pm 0.03$ & $175.71 \pm 14.15^{* *}$ & $126.59 \pm 3.31^{* * *}$
\end{tabular}

Statistically significant differences from the control group: $* P=0.02$; $* * P=0.0008$ and $* * * P<0.0001$.

Table 3

PARAMETERS OF INNATE HUMORAL IMMUNITY IN CHICKENS THAT RECEIVED DIET SUPPLEMENTED WITH ASCORBIC ACID $($ mean $\pm \mathrm{SD})$

\begin{tabular}{c|c|c}
\hline Group & $\begin{array}{c}\text { Lysozyme activity in blood } \\
\text { serum, } \mu \mathrm{g} / \mathrm{ml}\end{array}$ & $\begin{array}{c}\text { Circulating immune com- } \\
\text { plexes (CIC) in blood serum, } \\
\text { extinction units } \pm 100\end{array}$ \\
\hline 1. Control & $10.75 \pm 0.20$ & $4.13 \pm 0.44$ \\
2. $100 \mathrm{AA}$ & $6.36 \pm 0.54^{*}$ & $4.20 \pm 0.89$ \\
3. $500 \mathrm{AA}$ & $3.12 \pm 0.19^{*}$ & $2.43 \pm 0.35^{*}$ \\
4. $1000 \mathrm{AA}$ & $2.88 \pm 0.10^{*}$ & $3.07 \pm 0.71^{*}$ \\
5. $2000 \mathrm{AA}$ & $1.85 \pm 0.10^{*}$ & $1.47 \pm 0.19^{*}$
\end{tabular}

Statistically significant differences from the control 1 group: $* P<0.0001$ and $* * P=0.01$.

$\mathrm{mg} / \mathrm{kg}$. Increased MDA formation in the liver was detected with ascorbic acid doses of 1000 and $2000 \mathrm{mg} / \mathrm{kg}$.

Animals that were fed a diet that was supplemented with ascorbic acid at doses of 1000 and $2000 \mathrm{mg} / \mathrm{kg}$ had a higher concentration of uric acid in blood serum (Table 2). In addition, chickens that received ascorbic acid at doses 1000 and $2000 \mathrm{mg} / \mathrm{kg}$ displayed increased serum levels of creatinine compared to the control group (Table 2).
Parameters of innate humoral immunity in the treated chickens are shown in Table 2. Lysozyme activity in blood serum of chickens that were fed diets enriched with ascorbic acid at all doses was significantly decreased compared to that in the control group. The serum CIC level was decreased in chickens that were fed diets containing ascorbic acid at doses of 500, 1000 and $2000 \mathrm{mg} / \mathrm{kg}$ compared to that in the control group. Dose-dependent effects on lysozyme activity and CIC level were observed.

\section{DISCUSSION}

The focus of the present study was to provide a better understanding of the effects of dietary ascorbic acid supplementation to chicken. Chicken as an experimental model is especially useful in biological studies due to its high intensity of some metabolic processes (Klandorf et al., 1999). Birds differ from primates and guinea pigs by their capacity to synthesise ascorbic acid endogenously. However, a dietary supplementation of ascorbic acid can be beneficial for poultry to improve performance and egg production.

Ascorbic acid can act as an antioxidant, contributing to the total antioxidant capacity of an animal's antioxidant defence system. Intake of ascorbic acid in a low dose $(100 \mathrm{mg} / \mathrm{kg}$ diet) in our experiment indicated some increase of antioxidant activity in chicken organs. Our study demonstrated that hepatic GSH levels and GSH-Px activity were decreased in chickens that received 500, 1000 and $2000 \mathrm{mg} / \mathrm{kg}$ of ascorbic acid compared to those in the control group. The concurrent significant increase of MDA levels in chickens in the 1000 and $2000 \mathrm{mg} / \mathrm{kg}$ AA groups indicated an imbalance between anti-oxidative and pro-oxidative responses in liver. Elevated levels of MDA, which is an end product of polyunsaturated fatty acid oxidation, suggested that ascorbic acid at a dose of 1000 and $2000 \mathrm{mg} / \mathrm{kg}$ in the diet exhibited pro-oxidative effects.

The fraction of the dehydroascorbic acid of total vitamin $\mathrm{C}$ might provide useful information about the level of oxidative stress. Consequently, the ratio of DHAA to total ascorbate could be a marker of oxidative stress (Lykkesfeldt et al., 1997). The reduction of DHAA to AA occurs intracellularly and depends on both ascorbic acid and the dominant intracellular reductant glutathione. In the present study, we found AA overload to be a predictor of high liver concentrations of the oxidised form of ascorbic acid, DHAA.

We demonstrated that ascorbic acid stimulated cadmium accumulation in organs in a dose-dependent manner. This may be due to stimulation of the intestinal absorption of cadmium by ascorbic acid. The uptake of cadmium into enterocytes is mediated by the divalent metal transporter 1 (DMT1), which is a proton-coupled transporter (Park et al., 2002). The capacity of DMT1 transport is optimal at $\mathrm{pH} 5.5$ (Gunshin et al., 1997). Therefore, the absorption of cadmium was possibly increased by ascorbic acid via a decreased luminal $\mathrm{pH}$. 
This study indicated a close relationship between serum lysozyme and CIC levels, which are inflammatory markers, in chickens that were fed diets that were supplemented with 500,1000 and $2000 \mathrm{mg} / \mathrm{kg}$ AA. The bulk of CIC most likely contains antibodies against autoantigenic proteins, microbes and nuclear antigens, whereas lysozymes in serum predominately originate from macrophages (Torsteinsdottir et al., 1999; Wiik, 2003). Proteins that are modified by reactive oxygen species have been shown to elicit antibodies in a variety of diseases (Kurien and Scofield, 2008). The significant reduction of serum lysozyme and CIC levels in chickens that received $2000 \mathrm{mg} / \mathrm{kg}$ AA in the diet suggested that immune system function was suppressed, which may be associated with oxidative damage of macrophages and plasma cells.

Our study demonstrated that a high dose of ascorbic acid intake caused elevated levels of serum uric acid and creatinine. The antioxidant activity of ascorbic acid at low doses may improve kidney function by protecting renal tubular uric acid and creatinine secretory transporters from oxidative injury. Excessive ascorbic acid intake likely had an adverse effect on renal function, leading to reduced tubular excretion through the dysregulation of renal tubular uric acid and creatinine secretory transporters via ROS.

Uric acid is a powerful antioxidant (Waring, 2002). The observed high serum uric acid levels in chickens in the 1000 and $2000 \mathrm{mg} / \mathrm{kg}$ AA groups suggests that these chickens cannot manage ROS effectively and that transient impairment of renal functions may occur.

In summary, the results of our study demonstrated that high doses of ascorbic acid in the diet exhibited a pro-oxidative effect. The "threshold" concentration of ascorbic acid for this effect was $1000 \mathrm{mg} / \mathrm{kg}$ in the chicken diet. Furthermore, consistent exposure to high doses of dietary ascorbic acid (1000 and $2000 \mathrm{mg} / \mathrm{kg}$ ) induces loss of normal antioxidant reserves and immunosuppression, rendering the animals more susceptible to renal disturbances. In addition, a stimulatory effect of ascorbic acid on cadmium accumulation in organs and pro/anti-inflammatory activities was demonstrated.

\section{ACKNOWLEDGEMENTS}

The study was supported by grant 05.1452 of the Latvian Council of Science, "Peculiarities of the reactivity of organs and tissue under the modulating effect of nutrient components (heavy metals, natural antioxidants)"

\section{REFERENCES}

Anonymous (2000). Determination of lead, cadmium, copper, iron and zinc in food. Atomic absorption spectrophotometry after dry ashing. $J$. AOAC Int., 83 (5) (999.11). http://lib3.dss.go.th/fulltext/Journal/ J.AOAC\%201999-2003/J.AOAC2000/v83n5(sep-oct)/cs999_11.pdf.

Beutler, E., Duron, O., Kelly, B. (1963). Improved method for the determination of blood glutathione. J. Lab. Clin. Med., 15, 882-888.
Brown, S. (2008). Oxidative stress and chronic kidney disease. Vet. Clin. North Amer. Small Anim. Pract., 38, 57-66.

Close, B., Banister, K., Baumans, V., Bernoth, E. M., Bromage, N., Bunyan, J., Erhardt, W., Flecknell, P., Gregory, N., Hackbarth, H., Morton, D., Warwick, C. (1997). Recommendation for euthanasia of experimental animals: Part 2. Laboratory Anim., 31, 14-15.

Clynes, R., Maizes, J. S., Guinamard, R., Ono, M., Takai, T., Ravetch, J. V. (1999). Modulation of immune complex-induced inflammation in vivo by the coordinate expression of activation and inhibitory Fc receptors. J. Exp. Med., 189, 179-185.

Duarte, T. L., Lunec, J. (2005). When is an antioxidant not an antioxidant? A review of novel actions and reactions of vitamin C. Free Radic Res., 39, 671-686.

Eichhorn, F., Zelmanovski, S., Lew, E., Kutenberg, A., Fancas, B. (1961). Improvement of uric acid determination by the carbonate method for serum and urine. J. Clin. Pathol., 14, 450-452.

Eisner, C., Faulhaber-Walter, R., Wang, Y., Leelahavanichkul, A., Yuen, P. S. T., Mizel, D, Star, R. A., Briggs, J. P., Levine, M., Schnermann, J. (2010). Major contribution of tubular secretion to creatinine clearance in mice. Kidney Int., 77, 519-526.

Gobe, G., Crane, D. (2010). Mitochondria, reactive oxygen species and cadmium toxicity in the kidney. Toxicol. Lett., 198, 49-55.

Gunshin, H., Mackenzie, B., Berger, U. V., Gunshin, Y., Romero, M. F., Boron, W. F., Nussberger, S., Gollan, J. L., Hediger, M. A. (1997). Cloning and characterization of a mammalian proton-coupled metal-ion transporter. Nature, 388, 482-488.

Klandorf, H., Probert, I. L., Iqbal, M. (1999). In the defence against hyperglycaemia: An avian strategy. World's Poult. Sci. J., 55, 251-268.

Kohen, R., Nyska, A. (2002). Oxidation of biological systems: oxidative stress phenomena, antioxidants, redox reactions, and methods for their quantification. Toxicol. Pathol. 30, 620-650.

Kono, H., Chen, C., Ontiveros, F., Rock, K. L. (2010). Uric acid promotes an acute inflammatory response to sterile cell death in mice. J. Clin. Invest., 120, 1939-1949.

Kurien, B. T., Scofield, R. (2008). Autoimmunity and oxidatively modified autoantigens. Autoimmun. Rev., 7, 567-573.

Lykkesfeldt, J., Loft, S., Nielsen, J. B., Poulsen, H. E. (1997). Ascorbic acid and dehydroascorbic acid as biomarkers of oxidative stress caused by smoking. Amer. J. Clin. Nutr., 65, 959-963.

Mitch, W. E., Johnson, M. W., Kirshenbaum, J. M., Lopez, R. E. (1981). Effect of large oral doses of ascorbic acid on uric acid excretion by normal subjects. Clin. Pharmacol. Ther., 29, 318-321.

Park, J. D., Cherrington, N. J., Klaassen, C. D. (2002). Intestinal absorption of cadmium is associated with divalent metal transporter in rats. Toxicol. Sci., 68, 288-294.

Pinto, R., Bartley. W. (1969). The effect of age and sex on glutathione reductase and glutathione peroxidase activities and on aerobic glutathione oxidation in rat liver homogenates. Biochem. J., 112, 109-115.

Poljsak, B., Gazday, Z., Jenko-Brinkovec, S., Fujs, S., Pesti, M., Belagyi, J., Plesnicar, S., Raspor, P. (2005). Pro-oxidative vs antioxidative properties of ascorbic acid in chromium (VI)-induced damage: An in vivo and in vitro approach. J. Appl. Toxicol., 25, 535-548.

Riha, J. (1979). The use of polyethyleneglycol for immune complex detection in human sera. Immunology, 16, 489.

Shugar, D. (1952). Enzymatic assay of lysozyme. Biochim. Biophys. Acta, 8, 302-309.

Surai, P. F., Noble, R. C., Speake, B. K. (1996). Tissue specific differences in antioxidant distribution and susceptibility to lipid peroxidation during development of the chick embryo. Biochim. Biophys. Acta, 1304 (1), 1-10.

Surai, P. F., Speake, B. K., Noble, R. C., Sparks, N. H. C. (1999). Tissue-specific antioxidant profiles and susceptibility to lipid peroxidation of newly hatched chick. Biol. Trace Elem. Res., 68, 63-78. 
Torsteinsdottir, I., Hakansson, L., Hallgren, R., Gudbjornsson, B., Arvidson, N. G., Venge, P. (1999). Serum lysozyme: A potential marker of monocyte/macrophage activity in rheumatoid arthritis. Rheumatology, 38, 1249-1254.

Waring, W. S. (2002). Uric acid: An important antioxidant in acute ischemic stroke. Int. J. Med., 95, 691-693.

Received 26 June 2012
Wiik, A. (2003). Autoantibodies in vasculitis. Arthritis Res. Ther., 5, 147-152.

Winkler, B. C., Orselli, S. M., Rex, T. C. (1994). The redox couple between glutathione and ascorbic acid: A chemical and physiological perspective. Free Radic. Biol. Med. 17, 333-349.

Грант Х. Я., Яворковский Л. И., Блумберга И. А. (1973). Сравнительная оценка некоторых методов количественного определения лизоцима в сыворотке крови. Лаб. дело, 5, 300-304.

\section{ASKORBĪNSKĀBES ANTIOKSIDATĪVĀ/PROOKSIDATĪVĀ AKTIVITĀTE ATKARĪBĀ NO KONCENTRĀCIJAS CĀḶU ORGANISMĀ}

C vitamīns piedalās daudzos vielmainas procesos. Tas stiprina organisma imūnsistēmu, piedalās biologískās oksidēšanās un reducēšanās procesos. Askorbīnskābe un dehidroaskorbīnskābe veido redoks sistēmu un ir saistītas ar glutationa sistēmu. Dažāau stresu ietekmē askorbīnskābes koncentrācija audos samazinās. Tādēl barību vajag bagātināt ar šo vitamīnu. Darba mērķis bija pētīt dažādus oksidatīvā stresa biomarkierus cāḷu organismā, kadmija akumulāciju orgānos, imūnsistēmas aktivitāti un nieru funkcijas izmaiṇas askorbīnskābes ietekmē atkarībā no tās koncentrācijas barībā. Eksperimentos izmantojām vienu dienu vecus Lohmann Brown gailī̌sus, kurus sadalījām piecās analogās grupās. Cāli san̄èma kombinēto barību bez vai ar askorbīnskābes piedevām $(0,100,500,1000$ un 2000 mg/kg) četru nedēḷ laikā. Konstatējām, ka askorbīnskābe nelielā koncentrācijā (100 mg/kg barības) cāḷu organismā darbojas kā antioksidants. Pētījumā pierādīts, ka, palielinot šì vitamīna daudzumu barībā (1000 un $2000 \mathrm{mg} / \mathrm{kg}$ ), dzīvnieku organismā mainās antioksidatīvo - prooksidativo procesu līdzsvars, un tā rezultātā attīstās oksidatīvais stress: aknās palielinās C vitamīna oksidētās formas — dehidroaskorbinskābes daudzums, samazinās glutationa līmenis un glutationperoksidāzes aktivitāte, uzkrājas nepiesātināto taukskābju oksidēšanas gala produkts malondialdehīds, inducējās nespecifiskās imunitātes supresija, traucētas nieru funkcijas. Novērojām, ka askorbīnskābe, atkarībā no koncentrācijas, veicina smago metālu, t.sk. kadmija akumulāciju cāḷu aknās un nierēs. 


\title{
LONG-TERM CHANGES IN HYDROLOGICAL REGIME OF THE LAKES USMA, BURTNIEKS AND RĀZNA
}

\author{
Elga Apsīte, Mārtiṇš Kriḳitis, Inese Latkovska, and Andrejs Zubaničs
}

University of Latvia, Faculty of Geography and Earth Sciences, Raina bulv. 19, Rīga LV-1586, LATVIA; elga.apsite@lu.lv

Communicated by Māris Kḷaviṇš

\begin{abstract}
Changes in the hydrological regime of the lakes of Latvia have been caused by several natural and human factors. This publication summarises the results of research on the long-term and seasonal changes in the water level, and thermal and ice regimes of the three biggest lakes of Latvia (Usma, Burtnieks, and Rāzna) and their regional features in the period from 1926 to 2002. The levels of the lakes Usma and Rāzna have been controlled, but it can be considered that changes of the water level in Lake Burtnieks have been due to the impact of natural factors during the period from 1947 to 2002. Global climate warming has caused considerable changes in the hydrological regime of the lakes during the last decades, as the water level and temperature have increased and the number of days with ice cover and the thickness of ice have decreased. A positive trend in the freezing data and statistically reliable negative trend for the ice break-up date were observed for all the lakes. Lake Usma is located in the western part of Latvia, therefore, its hydrological regime, in particular, the thermal and ice regime, differs from those of lakes Burtnieks and Rāzna which are located in the northern and eastern part of Latvia, respectively.
\end{abstract}

Key words: lake, water table, water temperature, ice, long-term and seasonal changes.

\section{INTRODUCTION}

The territory of Latvia is rich in lakes. There are 2256 lakes with a surface area larger than 1 ha. The majority of lakes in Latvia are small. Only 16 lakes have an area larger than 1000 ha or 10 square kilometres (Tidrikis, 1995). Still, they account for $40 \%$ of the total area of the lakes. Most lakes are located in highlands (approximately $40 \%$ of the lakes occur in the highlands of Latgale and Augšzeme). The lowest number of lakes occur in Zemgale where the low plain and numerous rivers do not allow accumulation of water. The total area of lakes in Latvia is about 1000 square kilometres. This area amounts to about $1.5 \%$ of the area of Latvia, and the proportion is similar to that in Lithuania but considerably less than in Estonia (5\%), Sweden $(8.5 \%)$ or Finland (9\%). In Latvia there are many lakes, as glaciers covered this territory in not so far distant past. The icecover and water resulting from its melting caused formation of a terrain rich in hilly and depressions, which facilitated flow of water from raised parts and its accumulation in lower areas. Lakes formed by pools in marshes and bogs are not recorded in Latvia, but their number could be above ten thousand. In the $20^{\text {th }}$ century, the number of lakes decreased due to overgrowing, drainage projects and merging of lakes.

Lakes are one of the most common landscape elements in Latvia and in the Baltic region, which includes also some highlands with lakes in Lithuania, Poland and Northern
Germany. Lakes are a natural indicator that reflects the water regime of the region and its variability. The dynamics of the condition of a lakes over time is best characterised by the water level regime and its changes brought about by natural and anthropogenic factors. Similar to fluctuation of the volume of discharge of waters, cyclic and periodic changes over the span of centuries are characteristic also for fluctuation lake levels. These cyclic fluctuations are caused by various macroprocesses, such as atmospheric circulation, changes in the solar radiation which determines the thermal and ice regime of the lakes, and the amount of precipitation (Glazačeva, 1975).

The history of the modification of the hydrological regime of lakes by human activity in Latvia started already in the $18^{\text {th }}-19^{\text {th }}$ centuries. The largest changes occurred in the $20^{\text {th }}$ century, with increased alteration made by land drainage, hydro-energy projects, fisheries and other management types that affected the level of lakes.

Wide research on the hydrological regime of Latvian lakes and its changes were carried out in the 1930s, for example, investigations on large lakes near Rīga by Stakle (1935) and on morphometric elements and regimes by Slaucītājs $(1935 ; 1937 ; 1938)$. In the 1950 s to 1970 s, studies were carried out on the morphometry of the Latvian lakes, etc. (Котов и др., 1958) and on the thermal and ice regime of rivers and lakes by Glazacheva (Глазачева, 1964; 1965; 
Glazačeva, 1975). The publications by Tidrikis (1995) and Glazačeva (2004) are among the last reviews on the hydrological regime of Latvian lakes and its changes. It should be noted that lately no broad research on this topic has been carried out, and generally, since 2003-2004, regular monitoring of Latvian lakes is no longer performed.

The objective of this study was to analyse long-term changes of hydrological regime, i.e. water level and temperature, ice occurrence, and regional features of the three largest Latvian lakes: Usma, Burtnieks, and Rāzna.

\section{MATERIALS AND METHODS}

Studied lakes. The three biggest lakes of Latvia (Usma, Burtnieks and Rāzna) that had long series of observation data and different physical geographic location (Fig. 1) were selected for the study. The main characteristics of the lakes are presented in Table 1.

Lake Usma $\left(57^{\circ} 12^{\prime} \mathrm{N} 22^{\circ} 10^{\prime} \mathrm{A}\right)$ is located in the western part of Latvia at $20.6 \mathrm{~m}$ a.s.1. (Eipurs, 1998) in the Ugāle plain of the Kursa lowland, in the Irbe river basin. The surface area of the lake is $37.2 \mathrm{~km}^{2}$. Usma Lake is a remnant of the Baltic Ice Lake. The lake bed stretches from the North to South with length $13.5 \mathrm{~km}$; the widest part $(6 \mathrm{~km})$ is in the middle part of the lake. Usma Lake is the second biggest lake in Latvia from the point of view of the water volume $\left(190\right.$ mill. $\left.\mathrm{m}^{3}\right)$ and the estimated water turnover is two years. It discharges to the Baltic Sea at its north-western end via the Engure River - Puzes Lake - and then Rinda and Irbe Rivers. In comparison to the other studied lakes, Lake

Table 1

MORPHOMETRIC PARAMETERS OF STUDIED LAKES (Tidriķis, 1995)

\begin{tabular}{l|c|c|c|c|c}
\hline \multicolumn{1}{c|}{ Lake } & $\begin{array}{c}\text { Watershed, } \\
\mathrm{km}^{2}\end{array}$ & $\begin{array}{c}\text { Surface } \\
\text { area, } \mathrm{km}^{2}\end{array}$ & $\begin{array}{c}\text { Volume, } \\
\text { mill. } \mathrm{m}^{3}\end{array}$ & $\begin{array}{c}\text { Maximum } \\
\text { depth, } \mathrm{m}\end{array}$ & $\begin{array}{c}\text { Average } \\
\text { depth, } \mathrm{m}\end{array}$ \\
\hline Usma & 396 & 37.2 & 190 & 27 & 5.4 \\
Burtnieks & 2215 & 40.1 & 88 & 3.3 & 2.4 \\
Rāzna & 221 & 57.6 & 405 & 17.0 & 7.1
\end{tabular}

Usma has a high average and maximum depth (5.4 $\mathrm{m}$ and $27 \mathrm{~m}$, accordingly).

Burtnieks Lake $\left(57^{\circ} 44^{\prime} \mathrm{N} 25^{\circ} 14^{\prime} \mathrm{A}\right)$ is the fourth biggest lake in Latvia. It is located at $39.5 \mathrm{~m}$ a.s.1. in the northern part of Latvia in the Tālava lowland (Tidrikis, 1994). The water surface area is $40.06 \mathrm{~km}^{2}$. The lake bed is of glacial origin and stretches in the direction from the North West to the South East. Its length is $13.3 \mathrm{~km}$, and maximum width is $5.5 \mathrm{~km}$. Lake Burtnieks is a shallow lake with average depth $2.2 \mathrm{~m}$ and maximum depth $3.3 \mathrm{~m}$. This lake represents a flow lake, as water turnover takes place on average six to seven times per year (in spring once every 2-3 weeks and in summer once in three months). It discharges to the Riga Gulf via the Salaca River at the north-western end of the lake where the width at the discharge is $25-30 \mathrm{~m}$. Lake Burtnieks has the biggest basin $\left(2215 \mathrm{~km}^{2}\right)$, which exceeds its water surface area $\left(40.06 \mathrm{~km}^{2}\right)$ by 55 times. This factor causes large seasonal fluctuation of the water level.

Lake Rāzna (56 $19^{\prime}$ N $27^{\circ} 27^{\prime}$ A) is located in the South East part of Latvia on the highest part (163.4 m a.s.l) of the Latgale highland in the Rāznava hilly section (Lumane, 1997). This is the second biggest lake of Latvia from the aspect of the water surface area. Its area is $57.6 \mathrm{~km}^{2}$, and in 1956-1974, following the lowering of the level of Lubāna Lake, it became the biggest lake in Latvia. In terms of the water volume, Lake Rāzna is the biggest lake in Latvia. The total volume is 405 mill. $\mathrm{m}^{3}$ or $1 / 5$ of the aggregate volume of all lakes of Latvia. The lake bed is of glacial origin, rounded with a slight straighter stretch from the East to the West. Its length is $12.1 \mathrm{~km}$ and the largest width is 6.9 $\mathrm{km}$ in the east part of the lake. The average depth is $7 \mathrm{~m}$ and maximum depth is $17 \mathrm{~m}$. Lake Rāzna is a flow lake, and average discharge is $240 \mathrm{~mm}$. The discharge of the lake occurs in the western part via the Rēzekne River — Lake Kaunata. If the water level is high, discharge occurs also in the north-western part of the lake via Lake Zosnas and Kazupe River to the Malta River.

Data and methods. In the analysis of the hydrological regime of the studied lakes the hydrological monitoring data

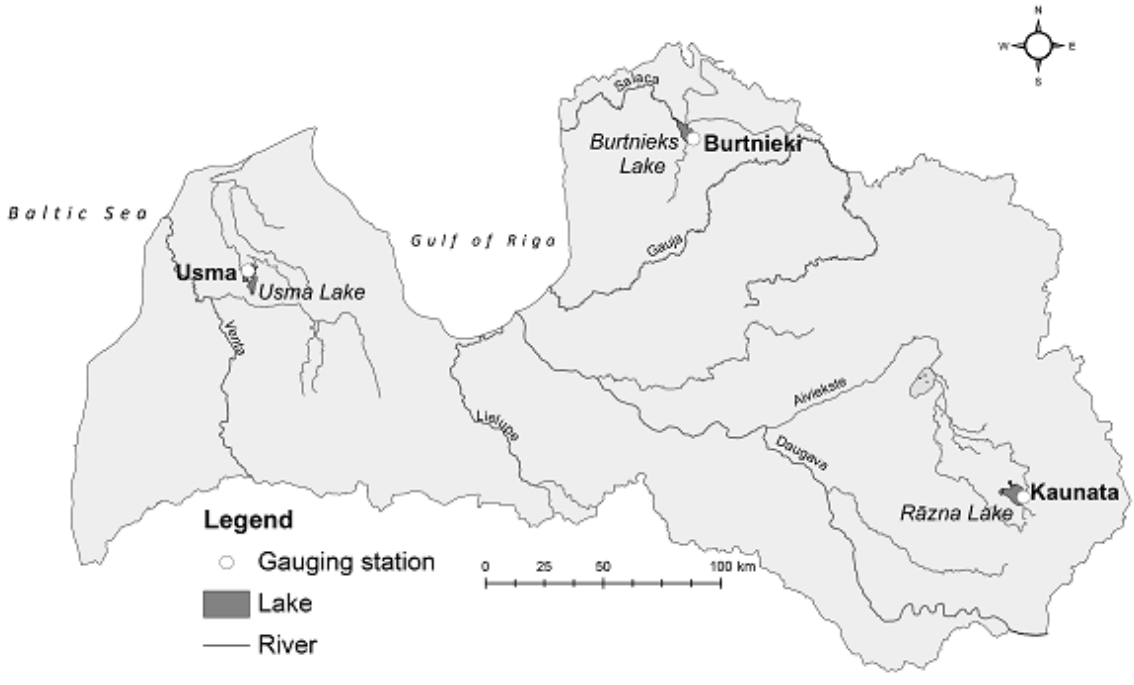

Fig. 1. Location of the studied lakes. 
STUDY PERIODS OF UTILIZED HYDROLOGICAL DATA

\begin{tabular}{lrccc}
\hline \multicolumn{1}{c}{ Data } & Lake Usma & Lake Burtnieks & Lake Rāzna \\
\hline Water level, cm & $1926-2002$ & $1947-2002$ & $1948-2002$ \\
Water temperature, ${ }^{\circ} \mathrm{C}$ & $1946-2002$ & $1946-2002$ & $1948-2002$ \\
Ice thickness, cm & $1929-1939$, & $1946-2002$ & $1948-2002$ \\
& $1946-2002$ & & \\
Number of days with ice & $1926-2002$ & $1946-2002$ & $1948-2002$ \\
Date of freezing & $1926-2002$ & $1946-2002$ & $1948-2002$ \\
Date of ice break-up & $1926-2002$ & $1946-2002$ & $1948-2002$
\end{tabular}

from the funds of the Latvian Environment, Geology and Meteorology Centre (Anonymous, 2011) and the publication of the Marine Board by Stakle and Kanavinšs (1941) were used. For the purpose of analysis of the water levels, the monthly mean data in centimetres above the zero post mark have been used and the observation periods for the studied lakes differ in this case (Table 2). Systematic monitoring of the water level of Lake Usma was started in September 1926 at Usmaciema hydrological station that was established by the Latvian Sea Department. The gauging station „Usma" is located $4 \mathrm{~km}$ to the North East of the mouth of the Engure River (Fig. 1). Its location and the zero mark of the post at $20.38 \mathrm{~m}$ a.s.l. have remained unchanged during the period of study. In the analysis of the water level of Lake Burtnieks the observations from the gauging station „Burtnieki” at the South East coast of the lake have been used, the zero mark of the HNS „Burtnieki” is located at $37.84 \mathrm{~m}$ a.s.1. In the case of Lake Rāzna the gauging station „Kaunata” is located at the east part of the lake and the mark of the zero post is at $160.57 \mathrm{~m}$ above the sea level.

In the analysis of the long-term trends of the water temperature the mean monthly data are used: for lakes Usma and Burtnieks from March to December, and for Lake Rāzna from April to December.

For the analysis of the ice regime the data on the ice thickness and duration days, freezing and break-up dates were used. The measurements of the thickness of the lake ice usually are performed from October to April six times per month, i.e. on the $5^{\text {th }}, 10^{\text {th }}, 15^{\text {th }}, 20^{\text {th }}, 25^{\text {th }}$ and the last date of the month, and as from the winter of 1975/1976 there have been individual periods or years when the observations were performed only three times per month. In the study measurements of the ice thickness in the middle of the lake are used, and in the case of Lake Burtnieks the missing data from the winter of 1969-1970 were replaced by inshore ice thickness observations that are not essentially different from the measurements of the central part of the lake. Afterwards, the mean and maximum annual ice thickness were calculated. In the present study, the date of freezing is the first day of ice occurrence, the date of ice break-up is considered as the date of disintegration of the ice cover in the period with regular ice observations, and the number of days with ice is calculated as the actual number of days on which ice occurred. For possibly immediate assessment of the climate changes in the Latvian lakes the severity index was calculated by Sztobryn et al. (2009). The index was used for the seasonal number of days with ice and the probability of ice occurrence.

The multivariate Mann-Kendall test (Lettenmaier, 1988; Loftis et al., 1991) was used to detect the trend shift in monthly and annual data analysis. The test was applied separately to each variable at each site, at a significance level of $P \leq 0.05$. The trend was considered statistically significant at the $5 \%$ level, if the test statistic was above 1.96 or below -1.96 .

In studies of hydro meteorological time series in the Baltic Sea area by Kḷaviņš et al. (2007) and Stips \& Lilover (2010) the so called breakpoints during the $20^{\text {th }}$ century were found. One of them refers to year 1987, which could have determined the long-term changes in hydro-climate patterns during last decades. Therefore, in our investigation the entire study period was divided into two periods: until 1987, with "no substantial" climate change impacts, and the period from 1988, with "substantial" climate change impacts on hydrological processes in Latvian lakes.

\section{RESULTS}

Changes in water level. In Latvia the big lakes have been regulated in recent or not so recent past, therefore, the long-term changes in their water level depend not only on the natural factors, mainly climate-related factors, but also anthropogenic activities. Concerning Lake Burtnieks during the study period from 1947 to 2002 there are no data about the works performed by humans in regulating the water level. Therefore, the long-term changes in the lake level can be deemed to be natural. This is confirmed by the comparison of the long-term changes in the lake level with the cycle of the changes in the flow of the Salaca River from 1951 to 2002. As it can be seen in Figure 2, two periods can be distinguished in the water regime of Lake Burtnieks and the Salaca River: low water from 1947 to 1977 and high water from 1978 to 2002. The long-term mean water level of the lake for numerous years was $40.1 \mathrm{~m}$ a.s.1., and $39.9 \mathrm{~m}$ during the low water period and $41.1 \mathrm{~m}$ during the high water

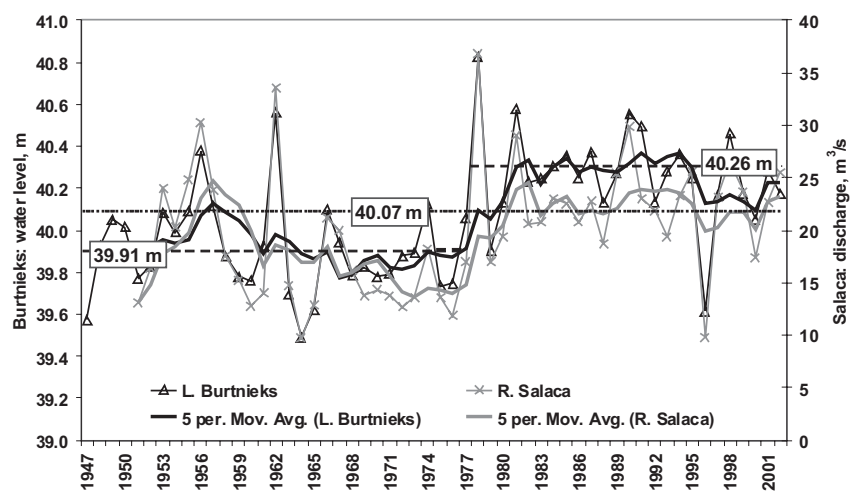

Fig. 2. Annual mean water levels and annual mean flow of the Salaca River during the period of 1947-2002. The dotted line is the long-term mean value of water level in the whole period; the interrupted lines are long-term mean values of water level of the studied periods 1947-1977 and 1978-2002. 
period. The long-term seasonal analysis showed that the statistically reliable positive trend at a significance level of $P \leq$ 0.05 could be observed for the water level of the lake from January to March and from June to September, but in the flow of the Salaca this trend could be observed only from January to March.

Lake Usma is peculiar concerning the fact that the regime of its water levels has been impacted by direct human activity. In 1969, on the Engure River not far from its mouth the eel catching device was constructed (Fig. 3). The water level in the lake was raised on average by $20 \mathrm{~cm}$. These changes are also reflected very well in the long-term changes in the mean water level where during the period from 1927 to 1968 it was $21 \mathrm{~m}$ and from 1969 to 2002 it was $21.2 \mathrm{~m}$ a.s.1. (Fig. 4). Thus, during the study period from 1927 to 2002, a statistically reliable positive trend could be seen from January to September, and during the period from 1927 to 1968 , a reliable positive trend could be identified only in March and April, when the level fluctuations were caused mainly by the natural conditions.

Lake Rāzna was regulated for several times (Fig. 5). During the period from 1951 to 1955 , Sprukti hydro power station

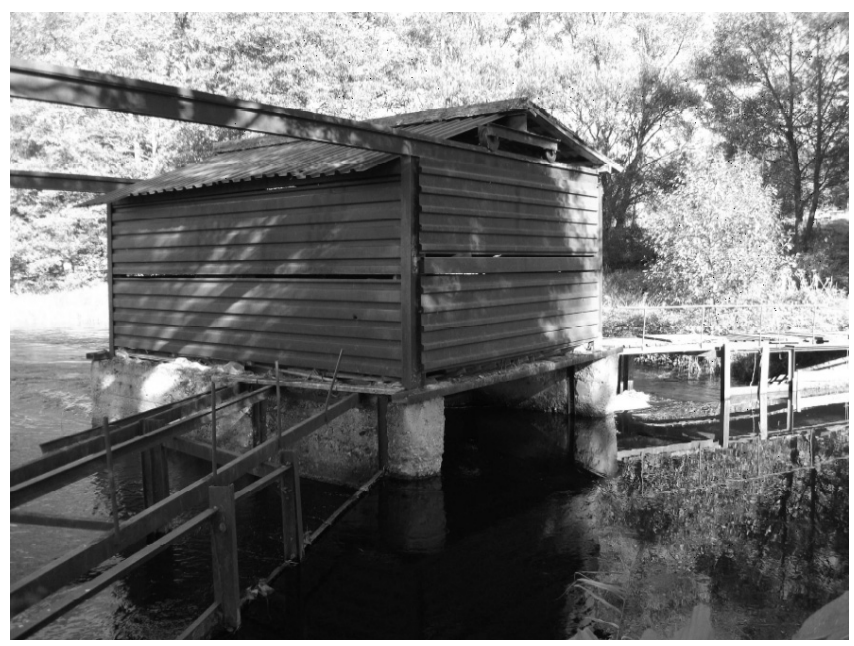

Fig. 3. The eel catching device on the Engure River not far from its outflow from Lake Usma. (Photo by Mārtiṇš Krikịitis, 2010).

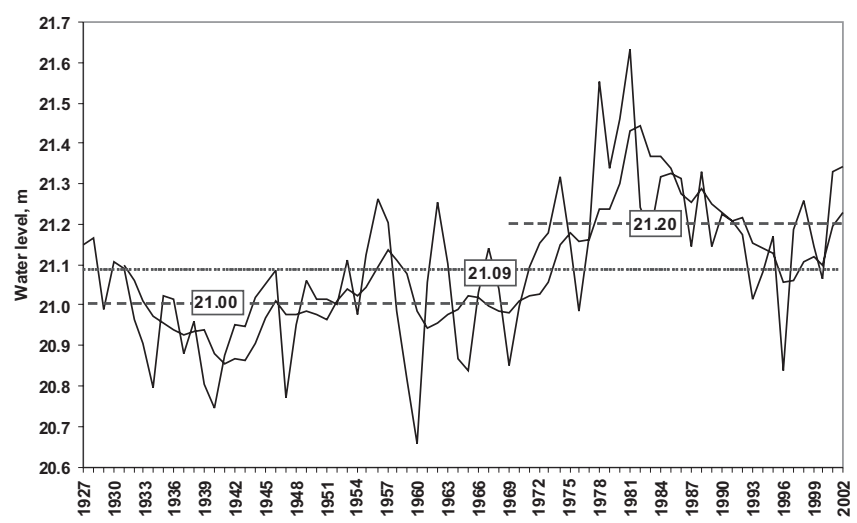

Fig. 4. Annual mean water levels of Lake Usma during the period of 1927-2002. The dotted line is the long-term mean value of water level of the whole period; the interrupted lines are long-term mean values of water level of the studied periods 1927-1968 and 1969-2002.

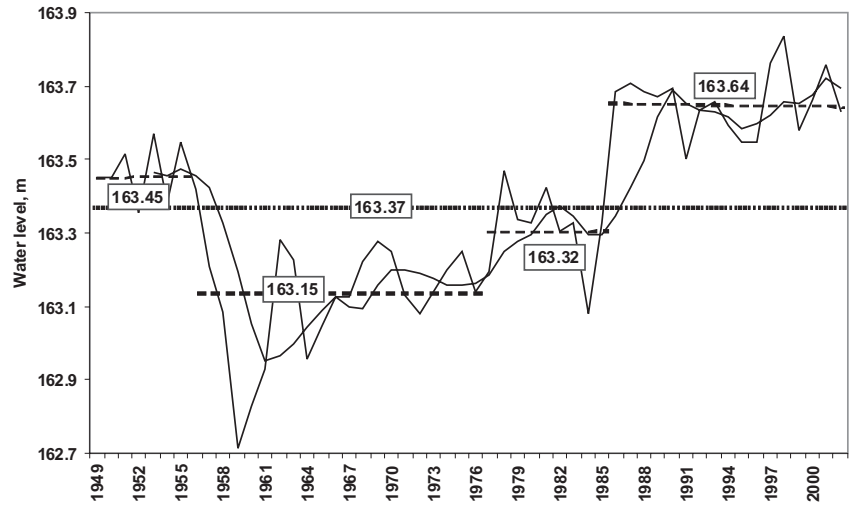

Fig. 5. Annual mean water level of Lake Rāzna during the period of 1949-2002. The dotted line is the long-term mean value of water level of the period 1949-2002; the interrupted lines are long-term mean values of water level of the studied periods 1949-1955, 1956-1977, 1978-1984 and 1985-2002.

(HPS) was built and it was in operation until 1977. During the period from 1956 to 1962, the flow of the lake was deepened along the section Lake Rāzna - Lake Kaunatas and on the upper course of the Rēzekne River to direct higher volumes of water to the Rēzekne River for the operation of Sprukti HPS. Following the deepening of the outflow the level of the lake decreased by $0.3 \mathrm{~m}$. After closing Sprukti HPS, the natural water level was restored at the lake for a couple of years from 1985 to 1992 (on average, up to $163.32 \mathrm{~m}$ a.s.1.), when the eel catching device was constructed and the level was raised by $29 \mathrm{~cm}$. During the period from 1993 to 2002, the Kaunata gates and Sprukti HPS were reconstructed and resumed power generation in 1996. The gates continue to maintain the level of the lake at the artificial level which was raised by another $5 \mathrm{~cm}$ following their reconstruction.

Changes in water temperature. The thermal regime of lakes is determined by the location of the lakes, climatic conditions, size and depth, inflow of underground and surface waters (streams, rivers). Lakes of the temperate latitude: in summer - direct, in winter - reverse stratification. In springs the water warms up slowly, later it accumulates the warmth, and during other seasons, the water is often warmer than the air. The water temperature is the highest in July and August and the lowest during the period of formation of the ice cover. In summer the upper layers of the deep lakes at the depth of 4-6 m warm up, the temperature practically does not change at other depth layers.

The results of the study of the water temperature demonstrated that the long-term mean temperature was the highest for Lake Usma where it amounted to $10.3{ }^{\circ} \mathrm{C}$, followed by Lake Burtnieks with $9.6{ }^{\circ} \mathrm{C}$ and Lake Rāzna with $9.1{ }^{\circ} \mathrm{C}$ (Fig. 6.). During the time period until 1987, the long-term mean temperatures in all the lakes were lower than during the time period from 1988 to 2002, when the climate warming could be observer. For lakes Usma and Rāzna the water temperature had increased by approximately $1{ }^{\circ} \mathrm{C}$. The long-term seasonal analysis demonstrated that the statisti- 


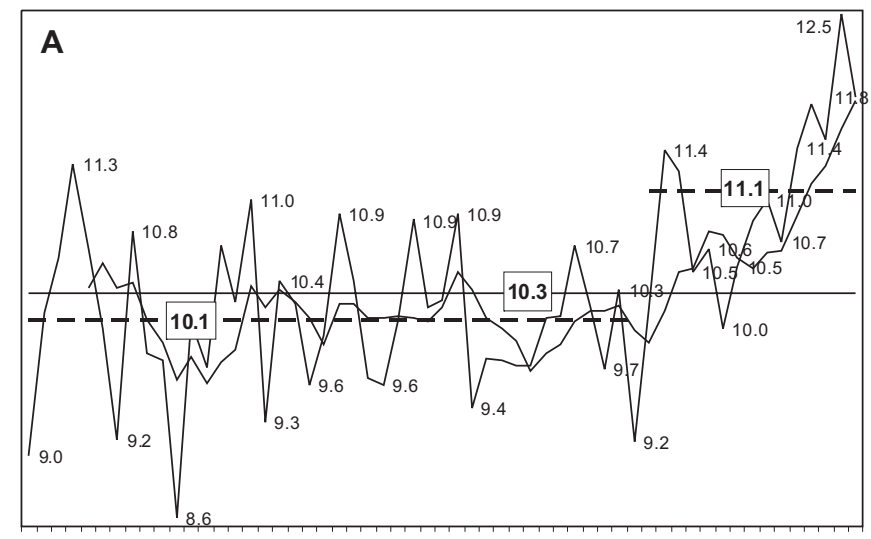

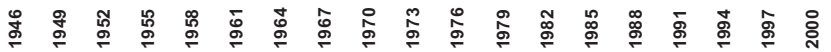

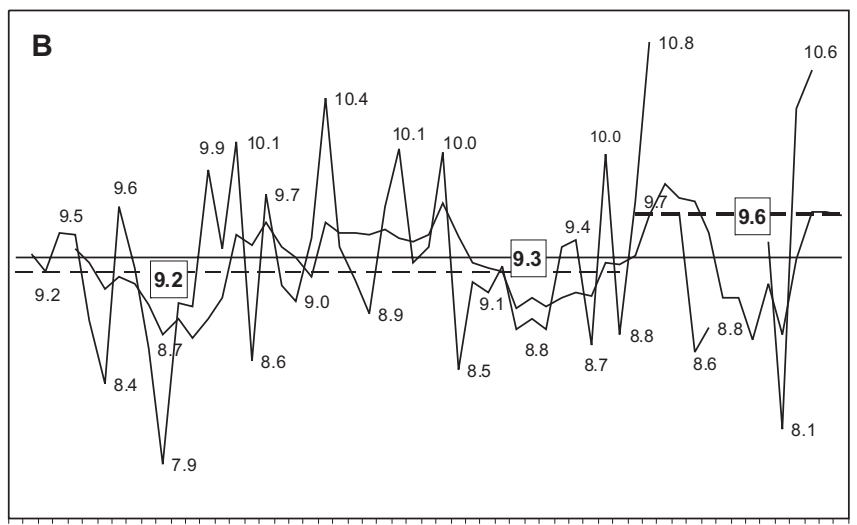

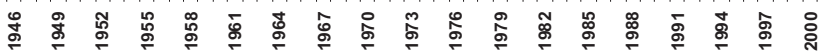

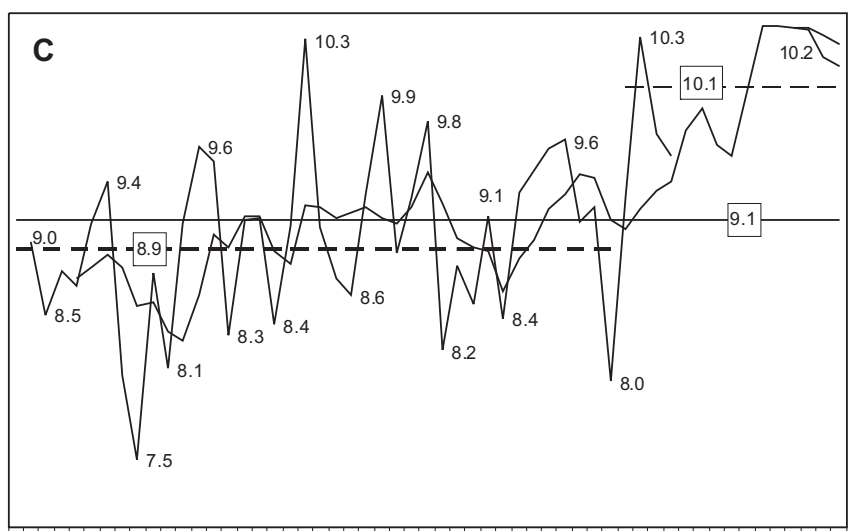

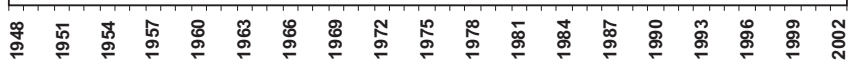

Fig. 6. Long-term water temperatures in lakes Usma (A), Burtnieks (B) and Rāzna (C). The uninterrupted horizontal line is the long-term mean value of water temperature of the whole study period; the interrupted lines are long-term mean values of water temperature of the studied periods 1946-1987 (A, B), 1948-1987 (C) and 1988-2002 (A, B, C).

cally positive trend could be seen during spring months March - April, and for Lake Rāzna also in July, August, and December.

Changes in ice freezing and break-up date. The ice formation in the Latvian lakes depends on the length of the period between the move of the daily mean temperature below $0{ }^{\circ} \mathrm{C}$ and cooling of the water in the lake to $0{ }^{\circ} \mathrm{C}$. Stable ice cover forms within 2-20 days after the first ice elements have appeared. At the highlands in the north and east part of
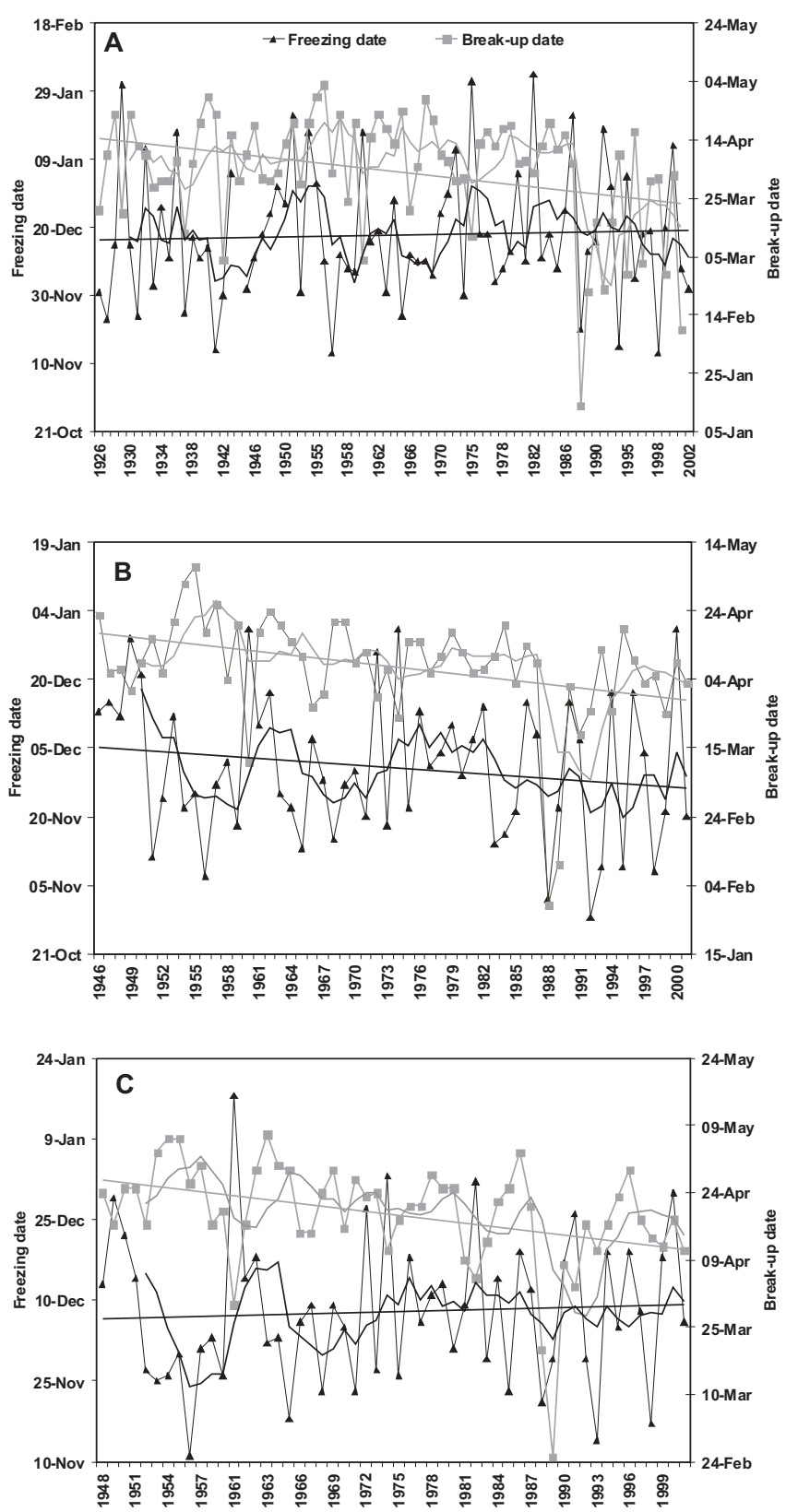

Fig. 7. Long-term freezing dates and break-up dates for lakes Usma (A), Burtnieks (B) and Rāzna (C). The horizontal lines are long-term mean values of freezing dates and break-up dates during the whole period.

Latvia the ice cover starts to form in the $2^{\text {nd }}$ half of November (Burtnieks - from the $25^{\text {th }}$ November to the $4^{\text {th }}$ December, Rāzna - from the $27^{\text {th }}$ November to the $8^{\text {th }}$ December), and in the West and middle part of Latvia - in the $1^{\text {st }}$ half of December (Usma - from the $2^{\text {nd }}$ to the $10^{\text {th }}$ December). It breaks up during the period from the $2^{\text {nd }}$ half of March to mid-April (Usma: the $31^{\text {st }}$ March - the $13^{\text {th }}$ April, Burtnieks: the $6^{\text {th }}-11^{\text {th }}$ April, Rāzna: the $18^{\text {th }}-25^{\text {th }}$ April), and within ten days after that the ice melts at the site. The climate warming resulted in the ice break-up already in mid-March or end of March, for example in the case of Lake Usma the mean date was the $17^{\text {th }}$ March, for Burtnieks it was the $25^{\text {th }}-30^{\text {th }}$ March and for Rāzna it was the $12^{\text {th }}$ April. As it can be seen from Figure 7, the trend that during the study period the ice formation date is later 
Table 3

EXTREME YEARS WITH THE EARLIEST AND THE LATEST DATE IN FREEZING AND BREAK-UP

\begin{tabular}{c|c|c|c|c|c}
\hline \multicolumn{2}{c|}{$\begin{array}{c}\text { Lake Usma } \\
(1926-2002)\end{array}$} & \multicolumn{2}{c|}{$\begin{array}{c}\text { Lake Burtnieks } \\
(1946-2002)\end{array}$} & \multicolumn{2}{c}{$\begin{array}{c}\text { Lake Rāzna } \\
(1948-2002)\end{array}$} \\
\hline $\begin{array}{c}\text { earliest } \\
\text { freezing }\end{array}$ & $\begin{array}{c}\text { latest } \\
\text { freezing }\end{array}$ & $\begin{array}{c}\text { earliest } \\
\text { freezing }\end{array}$ & $\begin{array}{c}\text { latest } \\
\text { freezing }\end{array}$ & $\begin{array}{c}\text { earliest } \\
\text { freezing }\end{array}$ & $\begin{array}{c}\text { latest } \\
\text { freezing }\end{array}$ \\
\hline
\end{tabular}

13.11.1998, 01.02.1975, 29.10.1992, 31.12.1960, 11.11.1956, 17.01.1961, 13.11.1956, 03.02.1982, 02.11.1988, 31.12.1974, 14.11.1993, 02.01.1975, 14.11.1941, 31.01.1930 07.11.1956 31.12.2000, 17.11.1998, 01.01.1983 15.11 .1993 29.12.1949 18.11.1995

\begin{tabular}{c|c|c|c|c|c}
\hline $\begin{array}{c}\text { earliest } \\
\text { break-up }\end{array}$ & $\begin{array}{c}\text { latest } \\
\text { break-up }\end{array}$ & $\begin{array}{c}\text { earliest } \\
\text { break-up }\end{array}$ & $\begin{array}{c}\text { latest } \\
\text { break-up }\end{array}$ & $\begin{array}{c}\text { earliest } \\
\text { break-up }\end{array}$ & $\begin{array}{c}\text { latest } \\
\text { break-up }\end{array}$ \\
\hline
\end{tabular}

05.01.1989, 03.05.1956, 29.01.1989, 07.05.1956, 25.02.1990, 07.05.1964, 09.02.2002 29.04.1941, 10.02.1990, 02.05.1955, 20.03. 1989, 06.05.1955, 29.04.1955, 11.03.1961 26.04.1958, 30.03.1961 06.05.1956, 28.04.1969, 24.04.1963, 03.051987 , 23.04.1929, $23.04 .1947 \quad 03.05 .1954$ 23.04.1931, $\quad 29.04 .1997$

23.04.1942,

23.04.1958,

23.04.1963,

23.04 .1966

can be seen for all the lakes, i.e. there is a positive trend, but it is not statistically significant. The ice break-up date is earlier, i.e. there is a negative trend and it is statistically significant at the $P \leq 0.05$.

The extreme freezing and break-up dates are summarised in Table 3. The variation of the dates among the studied lakes is higher in case of the freezing and lower in case of the ice break-up. It can be seen very well here that in 1961, 1989, 1990 the earliest break-up dates could be observed in all the lakes and in 1955, 1956, 1958, 1963 the latest break-up dates could be observed.

Changes in the numbers of days with ice cover and severity index. Until the year 1998, it could be observed that on average the ice cover was maintained in the Latvian lakes for 3.5-5 months or 6 months during severe winters. As it can be seen in Figure 8, the length of the ice cover varies among the studied lakes. The shortest ice cover length refers to Lake Usma and it equals to 107 days (104 days during the period 1945-2002), and the longest period refers to Burtnieks and equals to 128 days and to Rāzna where it equals to 133 days, i.e. 21 and 26 days longer, accordingly. During last 14 winter seasons (1988/89-2001/02), in comparison to the preceding study period (1926/27-1987/88), the number of days with ice cover had decreased on average by 14-33 days. It has decreased most for Lake Usma and least for lakes Burtnieks and Rāzna. Statistically significant long-term changes at the $P \leq 0.05$ were identified only for Lake Rāzna. Seasons with the longest and the shortest duration of ice cover are summarised in Table 4.

In order to establish the character of winter from the point of view of severity the severity index was calculated. As it can be seen in Figure 9, the severity index varies among the lakes: it is higher for the lakes located in the North and East
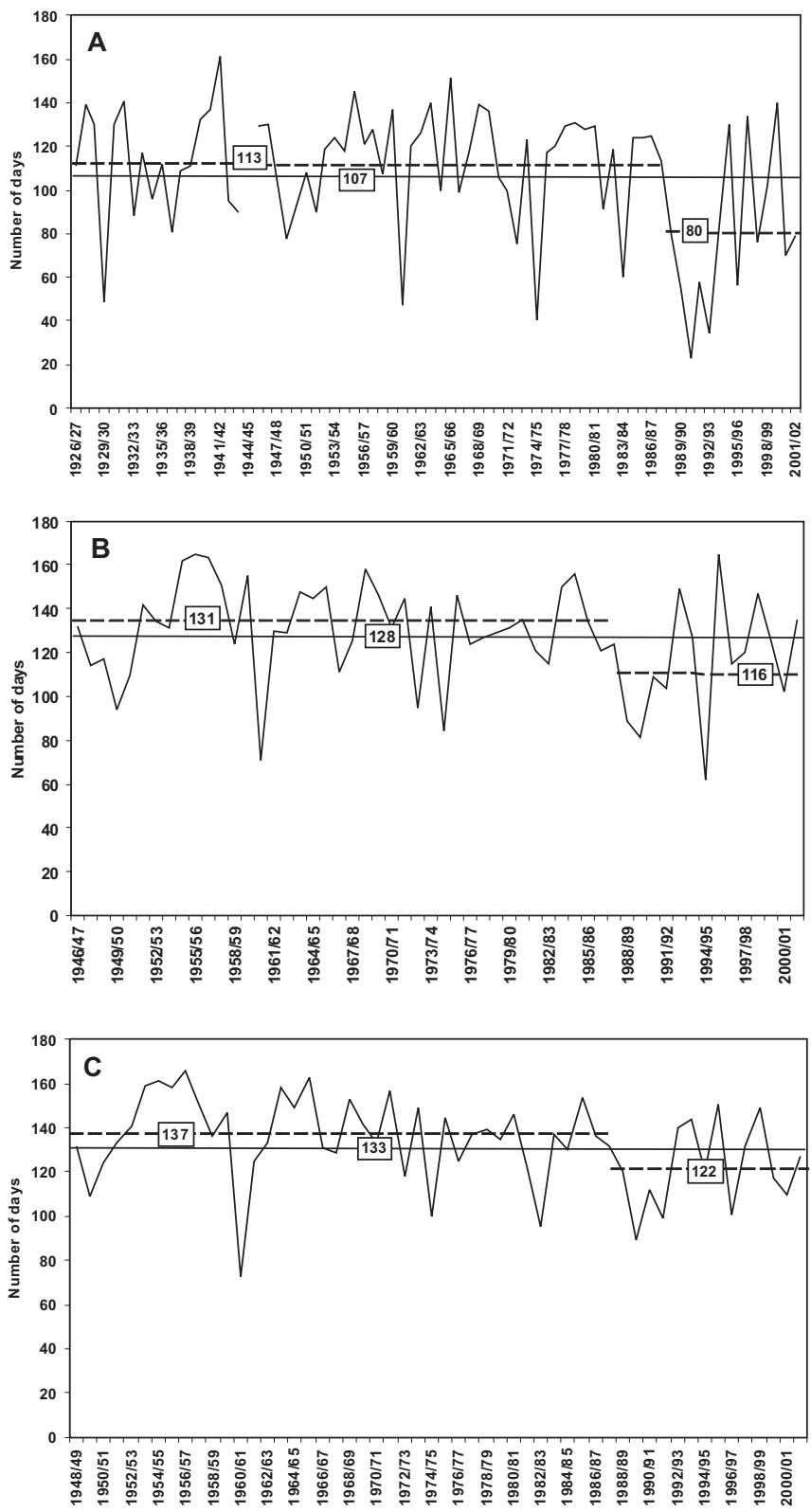

Fig. 8. Long-term numbers of days with ice cover of the lakes Usma (A), Burtnieks (B) and Rāzna (C). The uninterrupted line is the long-term mean value of the number of days with ice cover of the whole study period; the interrupted lines are the long-term mean values of the number of days with ice cover of the studied periods 1926/27-1987/88 (A), 1946/47-1987/88 (B), 1948/49-1987/88 and 1988/89-2001/02 (A, B, C).

of Latvia, which are Burtnieks and Rāzna, and it is lower for Lake Usma located in the western part. Based upon the calculated severity index the most severe and warmest winter seasons correspond to the seasons with the longest and the shortest duration of ice cover. The most severe winters could be observed from $1954 / 55$ to $1958 / 59$, 1965/66, $1968 / 69$ and 1995/96 seasons, and the warmest winters were in $1960 / 61,1974 / 75,1988 / 89,2001 / 01$ seasons. The statistically reliable negative trend at a significance level of $P \leq 0.05$ was found only for Lake Rāzna.

Changes in ice thickness. The changes in the ice thickness of the studied lakes can be described as pseudo-cycles, where periods with thicker and thinner ice cover alternate 
SEASONS WITH THE LONGEST AND THE SHORTEST DURATION OF ICE COVER

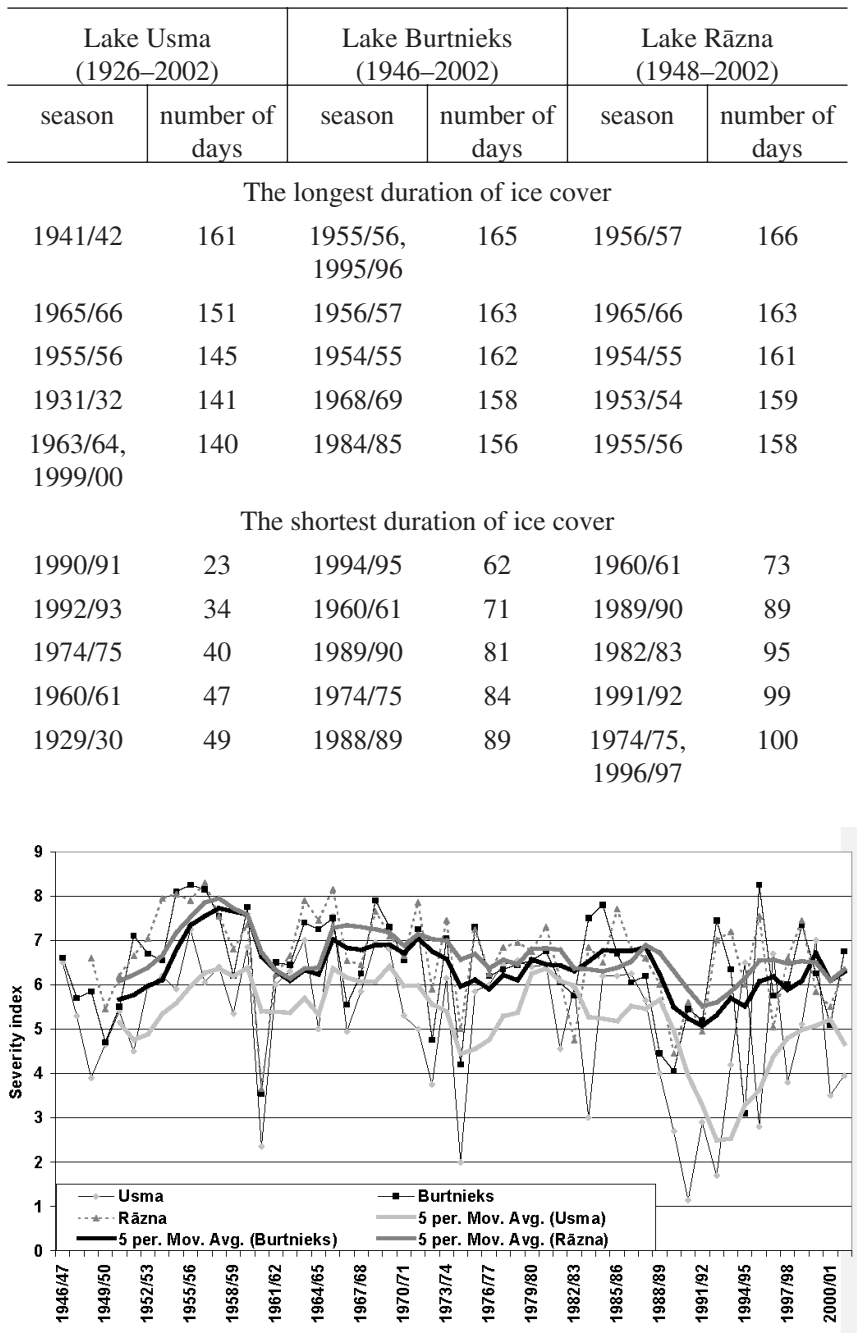

Fig. 9. Long-term severity indexes of the lakes Usma, Burtnieks and Rāzna.

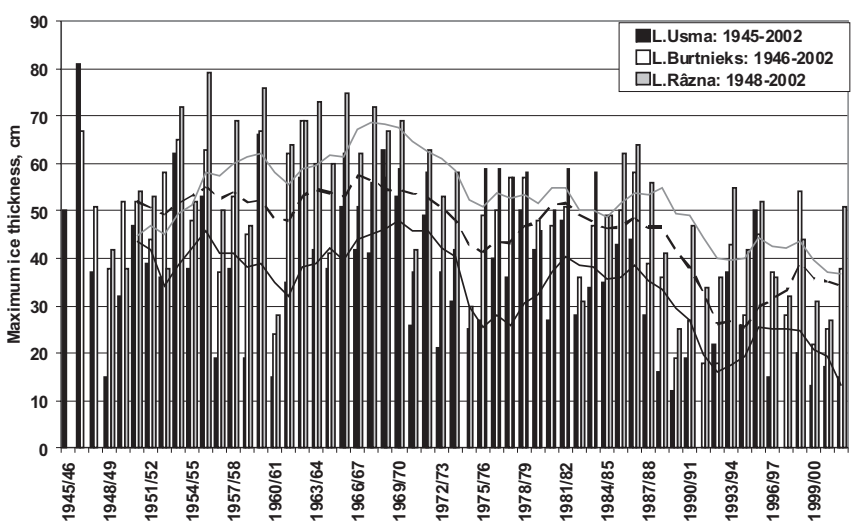

Fig. 10. Long-term annual maximum ice thickness of winter-spring season.

(Fig. 10). Ice thickness was pronouncedly higher during the period 1945-1973 when the maximum ice thickness levels were observed: in Lake Usma $81 \mathrm{~cm}$ in the season of

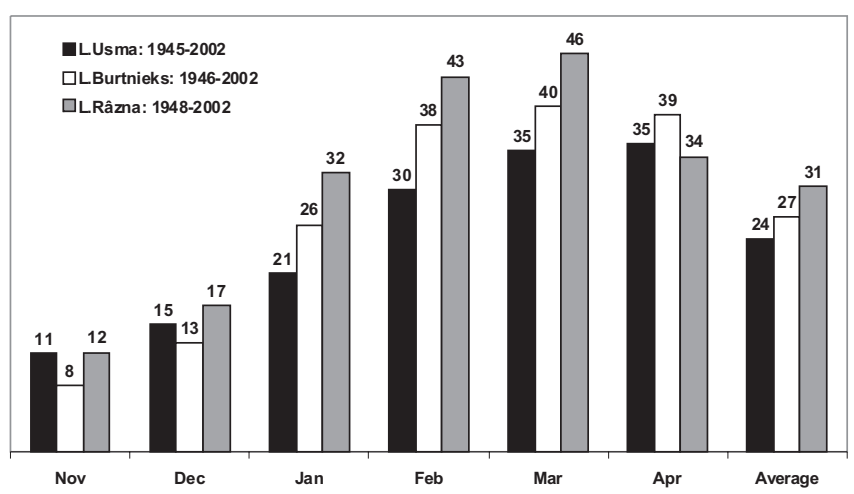

Fig. 11. Long-term monthly mean ice thickness.

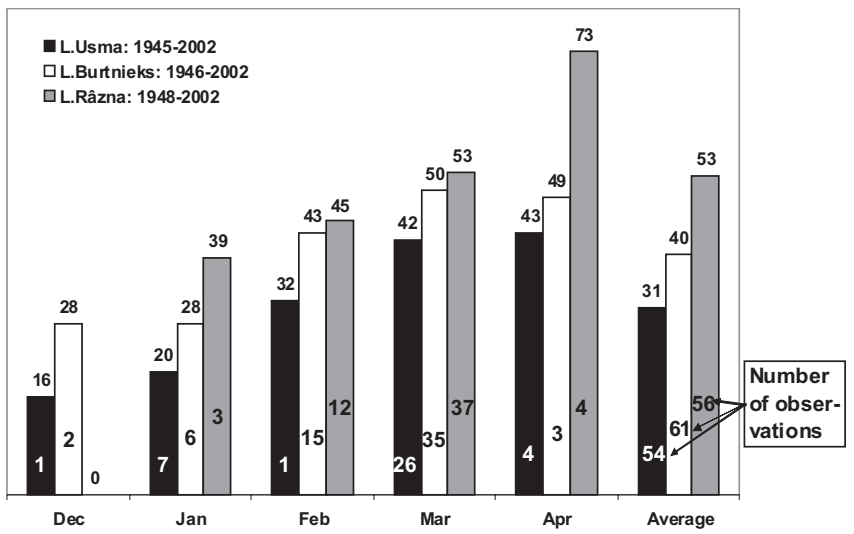

Fig. 12. Long-term monthly maximum ice thickness.

1946/47, in Lake Burtnieks $69 \mathrm{~cm}$ in the season of 1962/63, in Lake Rāzna $79 \mathrm{~cm}$ in the season of $1955 / 56$. The period of 1988-2002 is characterised by lower ice thickness, this was the period when the warming of the climate was observed and during this period also lower maximum ice thickness levels were observed: in Usma $12 \mathrm{~cm}$ and in Rāzna $25 \mathrm{~cm}$ in the season of 1989/90, in Burtnieks 18-19 $\mathrm{cm}$ in the seasons of 1989/90, 1991/92 and 1992/93. However, a statistically negative trend was identified only for the annual maximum ice thickness.

It is natural that in the Latvian lakes the mean and maximum ice thickness increase in the direction from west to east, it is $24-31 \mathrm{~cm}$ and $54-56 \mathrm{~cm}$, accordingly (Figs. 11 and 12). The highest mean and maximum ice thickness can be observed in March, but they can occur also in February and April. This depends on the heat exchange balance of the particular year and the climatic conditions of the year that determine the changes in the thermal and ice regimes of the lake.

Regarding observation of the mean ice thickness of lakes no statistically significant long-term changes were identified at the significance level of $P \leq 0.05$. In turn, concerning the maximum ice thickness data reliable negative trends were identified in November, January and February for Lake Burtnieks and March for Lake Usma and a positive trend was identified only for November for Lake Usma. 


\section{DISCUSSION}

The long-term hydrological changes of the Latvian lakes have been determined by the set of the natural, mainly climatic, and human activities factors. The adjustment works have been performed in all the three studied lakes, and they have served as an essential determinant of the long-term changes in the water level. Changes in the climatic conditions, in turn, have more defined the changes in the water temperature and the ice regime, as well as the changes in the water regime. From year 1929 to 1930, the water bed of the Salaca River was deepened along a section of $7 \mathrm{~km}$ from its mouth. In this relation the level of Lake Burtnieks was lowered by $1 \mathrm{~m}$ (Glazačeva, 1975). Regarding the study period from 1947 to 2002 there are no data about the water level adjustment works performed by a human at Lake Burtnieks. Therefore, these could be considered natural processes which have taken place mainly under the impact of the climate change and due to the lake itself naturally trying to restore the water level to the initial level (Fig. 2).

The long-term variation of the hydrological regime of the lake (water level, temperature and ice conditions) is strongly related to climatic variables. The air temperature is the dominant variable determining the hydrological processes and is also correlated to some extent with other relevant meteorological driving variables such as solar radiation, relative humidity and snowfall (Livingstone et al., 2010). For example, statistically, air temperature is often able to explain $60-70 \%$ of the variance in the timing of the break-up (ice-off) on lakes (Livingstone, 1997). In Latvia the latest study by Lizuma et al. (2007) has found that the annual mean air temperature has increased by $1.4{ }^{\circ} \mathrm{C}$ during last 50 years. In the study period from 1950 to 2003 , the highest increase in the mean air temperature was recorded in spring (March, April and May) and early winter (November and December). Also the mean annual maximum temperature increased more rapidly in April and May, while the minimum temperature increased more rapidly in winter. In lakes the annual and long-term water temperature changes resemble the changes in the air temperature (Glazačeva, 1975), which is proven also by the results of our study. During the ice-free period from 1988 to 2002 the water temperature had experienced a long-term increase by up to $1{ }^{\circ} \mathrm{C}$. Statistically reliable positive trends of the water temperature were found during the spring month, which indicate a faster removal of the ice coverage and faster warming up of the water.

Livigstone et al. (2009) pointed out that on interannual to interdecadal time-scales, the timing of ice-out, the temperature of rivers and lake surfaces and the discharges rates of streams are all directly influenced by regional climatic forcing. They consequently exhibit a high degree of coherence that is linked to the regional-scale special homogeneity of the relevant meteorological driving variables. The air temperature, which exhibits the highest degree of special homogeneity, is responsible for much, but not all, of the observed coherence. It was found by Livingstone and Dokulil (2001) in spring and summer; the coherence in lake surface water temperature was found to be reinforced by a regional coherence in meteorological driving forces other than air temperature (e.g., wind speed in spring and high-altitude cloud cover in summer). We can conclude that also we have found some regional differences in the surface water temperature among the studied lakes Usma, Burtnieks and Rāzna. Comparatively higher long-term average temperature was characteristic for Usma $\left(10.3{ }^{\circ} \mathrm{C}\right)$ followed by Burtnieks with $9.6{ }^{\circ} \mathrm{C}$ and Rāzna with $9.1{ }^{\circ} \mathrm{C}$.

Another factor which is referred to by many studies is the North Atlantic Oscillation (NAO) (e.g. George, 2000; Livingstone and Dokulil, 2001; Weyhenmeyer 2004; Kḷaviņs et al., 2009). Since air temperatures in the larger part of Europe in winter and spring are strongly influenced by the climate prevailing over the North Atlantic, it is not surprising that physical lake surface and rivers variables at these times of year are strongly linked to the NAO. As the NAO affects a number of meteorological driving variables, its influence on lakes is typically greater than that of any single variables (Livingstone et al., 2009).

The global warming during last decades has had an essential impact in determining the changes in the water regime of the lakes of Latvia: later freezing and earlier break-off dates can be seen, thus the number of days with ice coverage and the average and maximum thickness of ice have decreased. The climatic factors are the most important ones which determine the regional differences between the thermal and ice regimes which are, in turn, determined by the length of the period between the change in the average daily temperature below $0{ }^{\circ} \mathrm{C}$ and cooling of water to zero degrees in lakes; this depending on the size and depth of the lake, its geographic location, water exchange there, etc. (Glazačeva, 1975). Thus, small differences between the changes in the thermal and ice regime of the lakes appeared in the study, where by comparing Lake Usma of the west part of Latvia to the lakes of the east part of Latvia (Burtnieks and Rāzna) a slightly higher long-term average water temperature could be seen, and also the ice-coverage period and thickness of ice were lower at the place where winters are warmer and milder.

The results of our study on the long-term changes in the ice regime of lakes Usma, Burtnieks and Rāzna are similar to those in the Northern countries (Korhonen (2006) in Finland and Weyhenmeyer et al. (2004). The results of the analysis clearly showed that there is a statistically significant change towards earlier ice break-up in Finland from the late $19^{\text {th }}$ century to the present time. There is also a significant trend towards later freezing in the longer series, and thus also towards a shorter ice cover duration. The series of maximum thickness of ice showed both decreasing trends in the southern part of the country and increasing trends in the central and northern regions. These trends were statistically significant for approximately $50 \%$ of the observation sites. At the same time Weyhenmeyer et al. (2004) pointed out that the timing of ice beak-up responds much more strongly to the interannual variations in the air temperature in southern Sweden, where winters are relatively mild and duration 